ORNL/M--1862

DE93 012431

Metals and Ceramics Division

CERAMICS TECHNOLOGY PROJECT DATABASE:

SEPTEMBER 1991 SUMMARY REPORT

B. L. P. Keyes

June 1992

NOTICE: This document contains information of a preliminary nature. It is subject to revision or correction and therefore does not represent a final report.

Prepared for the

U.S. Department of Energy

Assistant Secretary for Conservation And Renewable Energy

Office of Transportation Technologies

EE 5101000

\author{
Prepared by the \\ OAK RIDGE NATIONAL LABORATORY \\ Oak Ridge, Tennessee 37831-6285 \\ managed by \\ MARTIN MARIETTA ENERGY SYSTEMS, INC. \\ for the \\ U.S. DEPARTMENT OF ENERGY \\ under contract DE-AC05-840R21400
}




\section{CONTENTS}

Page

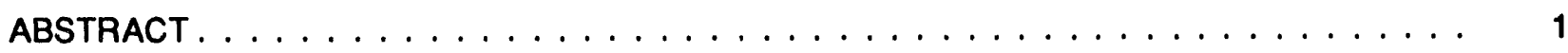

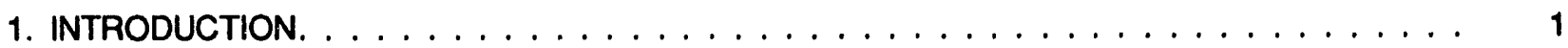

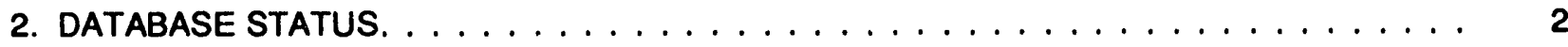

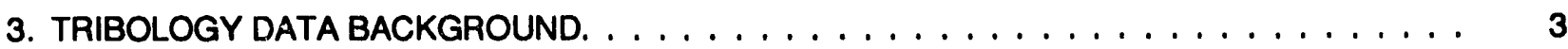

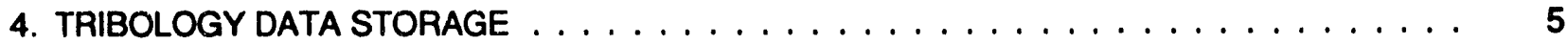

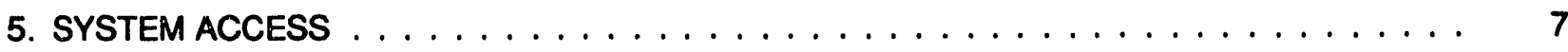

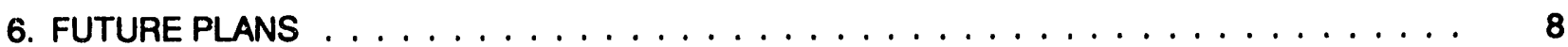

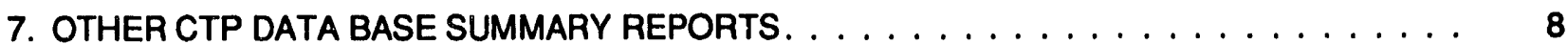

8. ACKNOWLEDGMENTS $\ldots \ldots \ldots \ldots \ldots \ldots \ldots \ldots \ldots \ldots \ldots$

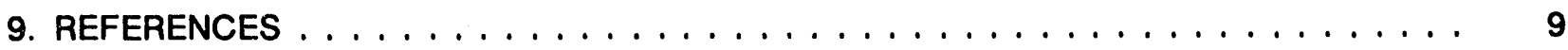

APPENDIX A. MATERIAL CHARACTERISTICS AND BACKGROUND DATA . . . . . . . . . . 23

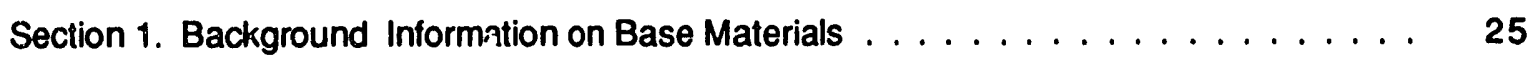

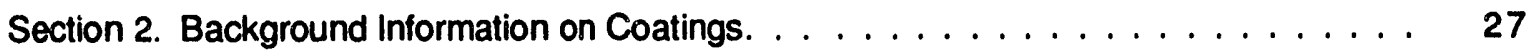

Section 3. Background Information on Lubricants . . . . . . . . . . . . . . . 31

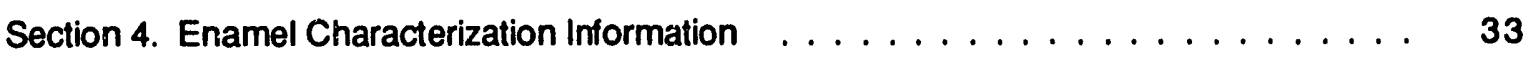

Section 5. Chemistries . . . . . . . . . . . . . . . . . . . . . . 35

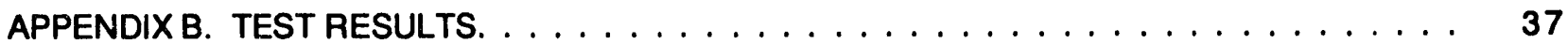

Section 1. Test Rig Descriptions . . . . . . . . . . . . . . . . . . . 39

Section 2. Wear Test Data from Battelle Columbus Laboratories . . . . . . . . . . . . . 43

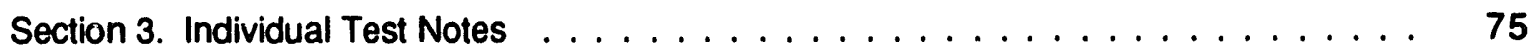

Section 4. Thermal Expansion Test Results . . . . . . . . . . . . . . . . . . 79

Section 5. Hardness Data . . . . . . . . . . . . . . . . . . . . . . . . . 81 


\title{
CERAMICS TECHNOLOGY PROJECT DATABASE: SEPTEMBER 1991 SUMMARY REPORT*
}

\begin{abstract}
The piston ring-cylinder liner area of the internal combustion engine must withstand very-hightemperature gradients, highly-corrosive environments, and constant friction. Improving the efficiency in the engine requires ring and cylinder liner materials that can survive this abusive environment and lubricants that resist decomposition at elevated temperatures. Wear and friction tests have been done on many material combinations in environments similar to actual use to find the right materials for the situation.

This report covers tribology information produced from 1986 through July 1991 by Battelle Columbus Laboratories, Caterpillar Inc., and Cummins Engine Company, Inc. for the Ceramic Technology Project (CTP). All data in this report were taken from the project's semiannual and bimonthly progress reports and cover base materials $t$, coatings, and lubricants. The data, including test rig descriptions and material characterizations, are stored in the CTP database and are available to all project participants on request. The objective of this report is to make available the test results from these studies, but not to draw conclusions from these data.
\end{abstract}

\section{INTRODUCTION}

Advanced engines operate at higher temperatures than normal diesel engines, so more refractory materials are needed for the components. Increasing the temperature also causes problems with the function and condition of the lubricants by breaking them down into corrosive byproducts and reducing lubricity on the contact surfaces. The new piston ring and cylinder liner materials must be able to withstand $10,000 \mathrm{~h}$ of operation under high-temperature, corrosive, and abrasive conditions to be considered usable on a commercial scale. While metals are commonly used in engines today, they lack the heat and corrosion resistance of ceramics and some cermets.

This report covers tribology information produced from 1986 through July 1991 by Battelle Columbus Laboratories, Caterpillar Iric., and Cummins Engine Company, Inc. for the Ceramic Technology Project (CTP) on numerous materials, including coatings and base materials, for use in the severe conditions of the cylinder. Most of the information was extracted from semiannual and bimonthly progress reports generated by the CTP.

"Research sponsored by the U.S. Department of Energy, Assistant Secretary for Conservation and Renewable Energy, Office of Transportation Technologies, as part of the Ceramic Technology Project of the Materials Development Program, under contract DE-AC05-84OR21400 with Martin Marietta Energy Systems, Inc.

tFor this report, "base material" refers to a material used by itself; it does not act as a coating on another material but may serve as a substrate. Base materials may be composed of ceramics, intermetallics, or metals, used alone or in combination. 
Tribology data storage presented several problems not encountered in working with most of the other test data. The number of possible materials involved, the types of materials (coatings, base materials, ion implants), and the importance of lubricants required the addition of several new fields. Parameters omitted in the original file structure for wear data were added when the importance of those items was realized. New files were added to contain information associated with the new parameters.

\section{DATABASE STATUS}

The CTP database presently contains 6,309 results on 27 different types of tests, 338 material characterizations, 13 lubricant characterizations, 101 coating characterizations, and 1,953 other associated records. A more detailed description may be found in Table 1.

Progress made since the last report includes the addition of tribology test results, a coatings characterization file, a lubricant identification file, a material name cross-reference file, a new study-search field, and a data classification field. The new coating and lubricant files were necessary to describe more accurately the materials used in the tribology tests. The field additions were enhancements designed to help the user locate data faster.

Ceramics lack a standard, industry-accepted identification system available for other materials, such as the Unified Numbering System (UNS) for metals. A given ceramic may be known by several different names ( $\mathrm{Z}-191$ is also called $\mathrm{PSZ}, \mathrm{ZrO}_{2}$, and zirconia), each correct but all different as far as a computer query is concerned. The MATNAMES file was created to simplify choosing a material name for use in a database query. This file contains a list of material names used in the database, cross indexed to composition, manufacturer's, and generic designations, all indicating the same material. This file could be useful for locating aliases for each material. When a standard system is accepted by the ceramic industry, the new nomenclature will be incorporated into the database.

The WBS-STUDY field, to be included in every file record, was added to facilitate locating all the data from a particular study. Database personnel usually collect data from one testing facility's work on one subject covering a particular time span. Recalling the information from that one study is necessary to verify and tabulate the data.

Data classification identifies information in a property data record according to its level of evaluation. Most of the data stored in the CTP database are semi-raw test data, having been converted from instrument readings to stresses, strains, etc. Some data are reported only as averages. Nominal values may be included for a general material comparison. The DATA-CLASS field has four possible values: "TEST" for semi-raw test data; "AVG" for averaged data from several tests nun under the same set of conditions; "NOM " for nominal, or typical, values; and "GOAL" for target values. If more than one test for a given set of conditions exists in a source, "TEST" is the default value. Otherwise, "AVG" is assumed.

Only the tribology data presently include values in the two fields mentioned above. Database personnel plan to extend the additions to the other contents as time allows. 


\section{TRIBOLOGY DATA BACKGROUND}

Information for this report was produced by three tribology studies funded by the CTP. All three studies focused on developing materials for piston ring and cylinder liner components for low heat-loss diesel engines. The period used for this report began in 1986 and ended in July1991. Some of the work is continuing and will appear in future database summary reports.

K. F. Dutrane ard P. A. Gaydos from Battelle Columbus Laboratories were the principal investigators for WBS 2.2.2-Studies of Dynamic Contact of Ceramics and Alloys for Advanced Heat Engines. The main objective of this study was to develop an understanding of the tribological problems of ceramic interfaces in advanced heat engines based on test data. Target parameters were determined by running chrome-plated ring specimens against cast-iron cylinder specimens in a diesel environment at $100^{\circ} \mathrm{C}$ for 10,000 hours. Commercially available SAE 30 oil was used as the lubricant. Battelle's test rig simulated the ring-cylinder interface by using less expensive flat specimens for both ring and cylinder components. One cylinder specimen was fixed, while the other was mobile for load control. Two ring specimens were mounted with pivot pins at specimen centers to provide self-alignment. The ring specimens reciprocated along $108 \mathrm{~mm}$ of the cylinder specimens at 500 to $1500 \mathrm{rpm}$, averaging speeds of 1.8 to $5.4 \mathrm{~m} / \mathrm{s}$. Heated exhaust from a $4500-W$ diesel engine was passed through a chamber surrounding the test specimens. 1 Figure 1 shows a schematic diagram of this configuration. Materials tested include a variety of plasma-sprayed coatings as well as non-coating ceramics. Data from this study are tabulated in Appendix $B$, Section 2a. Since this work is continuing, any data generated in the future will be stored and reported as they become available.

C. D. Weiss, F. A. Kelley, and M. H. Haselkorn2 were the investigatcis for WBS 1.3.1-WearResistant Coatings, the CTP part of Caterpillar's work on developing materials fo: in-cylinder components. This study involved more coatings than the Battelle study and included ceramics, cermets, metals, and enamels. Coating processes included plasma spraying, chemical and physical vapor deposition, lowtemperature arc-vapor deposition, and dipping (with and without added particles) on hot and cold substrates. Initial candidate materials were screened at Caterpillar using a Falex Model 6 testing machine. Figure 2 shows a schematic diagram of the configuration. Disks of mild steel, tool steel, and cast iron were coated, then tested against pins of $440 \mathrm{C}$ steel, zirconia, and alumina. Materials that performed best were further tested on a Hohman Double-Rub Shoe Model 6 tester (Fig. 3). This configuration simulated the ring-cylinder contact interface by using a rotating disk to abrade two fixed shoes. Both shoes and the disk were coated with different combinations of materials. All Holıman tests were run at $350^{\circ} \mathrm{C}$ using a Lubrizol experimental synthetic oil. Average speed was $3.43 \mathrm{~m} / \mathrm{s}$ with a load of $9.08 \mathrm{~kg}$ force. 2 The data sources did not list numeric values for all the wear coefficients but provided approximate levels of wear instead (low, medium, and high). Information in the database for this study is stored the way it appeared in the original data source. All Caterpillar test results are given in Appendix B, Sect. $2 b$. 
Cummins Engine Company, like Caterpillar, has been making, designing, and developing engine components for many years. M. G. S. Naylor ${ }^{3}$ was the principal investigator for WBS 1.3.1-Development of Wear-Resistant Coatings for Diesel Engine Components. The main objective of this study was to develop coatings for in-cylinder components that would have wear coefficients of $5 \times 10^{-12}$ to $5 \times 10^{-11}$ $\mathrm{mm} 3 / \mathrm{mm} / \mathrm{N}$; have friction coefficients of 0.1 or better when lubricated and 0.2 or better unlubricated at room temperature and at $350^{\circ} \mathrm{C}$; have good thermal shock resistance, high adherence, and substrate compatibility up to $650^{\circ} \mathrm{C}$; and exhibit good uniformity and reproducibility. 3 All coatings were tested on a Cameron-Plint wear tester at $20 \mathrm{~Hz}$ with a $5 \cdot \mathrm{mm}$ stroke length. The cylinder specimen was a flat, $7.5-\mathrm{mm}$-wide sample, while the ring had a cylindrical radius of $50 \mathrm{~mm}$. Figure 4 shows the testing configuration with the specimens in the lubricant bath tub. CE/SF $15 \mathrm{~W} 40$ mineral oil-based lubricant was used in both fresh (CE/SF15W4OF) and engine-tested (CE/SF15W40U) specimens, added at the rate of one drop every $10 \mathrm{~s}$ for $6 \mathrm{~h}$, if the test lasted that long. Unlubricated tests were run for only 30 to $60 \mathrm{~min}$. Materials for this study included metal, cermet, and ceramic coatings slurry- or plasma-sprayed onto stainless steel, mild steel, tool steel, or cast-iron substrates. Several ion-nitrided specimens were also tested. Results from this study are listed in Appendix B, Sect. 2 c.

Comparing test results from the different studies was hindered due to a difference in wear factor calculation methods. Battelle Columbus Laboratories and Caterpillar used the same method, but only a few of the Caterpillar tests were reported with numeric wear values. ${ }^{2}$ Their wear factors were calculated by:

$$
k=\frac{V}{L d}
$$

where $k=$ wear factor, $\mathrm{mm}^{3} / \mathrm{Nm}$, (quantity of removed material per unit distance and force)

$V=$ wear volume, $\mathrm{mm}^{3}$, (quantity of material removed)

$L=$ applied bad, $N$, and

$d=$ sliding distance, $m$.

Battelle Columbus Laboratory also used the Archard equation to calculate wear in dimensionless units for a few tests:

$$
\text { where } \begin{aligned}
V & =\frac{k L d}{3 H} \\
K & =\text { wear volume, } \mathrm{mm}^{3}, \\
L & =\text { wear factor, } \\
& =\text { load, } \mathrm{kgf}, \\
d & =\text { sliding distance, } \mathrm{mm}, \text { and } \\
H & =\text { hardness, } \mathrm{kg} / \mathrm{mm} .
\end{aligned}
$$


The Cummins study used an Arrhenius function to determine the wear coefficient. ${ }^{3}$

$$
W=W_{0} \exp \left(-\frac{Q}{R T}\right)
$$

where $\mathrm{W}=$ wear coefficient, $\mathrm{mm}^{3} / \mathrm{mm} / \mathrm{N}$, (quantity of removed material per unit distance per unit force)

$$
\begin{aligned}
W_{0} & =\text { constant }, \\
Q & =\text { activation energy, } \\
R & =\text { gas constant, and } \\
T & =\text { absolute temperature } .
\end{aligned}
$$

Since the units for this equation were not consistent with those used by the other studies, a conversion factor was applied to correct the problem. The reader should remember the differences in the machines used to test the materials and the differences in wear factor calculations when comparing the data. Information presented in the appendices of this report is separated by study to avoid confusing the wear factor calculations.

\section{TRIBOLOGY DATA STORAGE}

Data used in this report are stored on a 20-MB Bernoulli cartridge using $\mathrm{ABASE} / \mathrm{IV}^{\mathrm{m}}$ (version 1.1) on a Northgate $486 / 25$ microcomputer. The database consists of 35 interrelated files linked by sets of codes and includes test results, material characterizations and background information, testing equipment details, and other test/specimen data. Figure 5 shows the relationships among the files used to store tribology data.

Tribology tests often use more than one material per test. Therefore, the number of material fields has been increased and each one coded to indicate which material was used in a specific position. Material fields ending with a "1" refer to the moving specimen; those ending with a "2" refer to the stationary specimen. Each position (moving or stationary) refers to a coating and batch code, a substrate and batch code, and a wear coefficient, if available. Base materials appear in the substrate fields whether they are coated or not. Only coating materials appear in the coating fields to avoid problems when a link is made to the associated characterization information. Coating background data are stored in a different file than base material background data. More information on the materials used in a test may be found in the COATINGS and MATLCHAR material characterization files.

Since the manufacturer's batch codes for the materials used in these studies were unknown, database personnel improvised batch codes as: Material supplier or lab doing the coating/coating method if material is a coating/testing or reporting facility. These homemade codes will be replaced with actual manufacturer's codes when possible. 
The WEARDATA file contains all the test results. Each test record contains results and conditions for one test, one step in a multipart test, or on a group of tests run under the same conditions. The value in DATA-CLASS indicates whether the results are for one test (TEST), an average of several tests (AVG), or a nominal value (NOM). The defaults for DATA-CLASS are TEST if more that one result is listed for a given set of conditions and AVG otherwise.

Other fields provide links to other files containing additional information about the test or the materials. An affirmative value in the SEETEXT field indicates that additional comments on the results are available in the DATATXT file (for expanded test notes). Lubricant information may be found in the file LUBRICNTS using LUBRICANT as the key. TEST-RIG links the test results data with details about the test apparatus in the TESTBKGD file. Expanded references may be found in the file named CERSOURC. Chemistries, if available, may be found in the CHEMSTRY file using the material or coating name and related batch code as a key. Additional material or coating notes are located in TEXTUF, keyed by material or coating name and batch code. The WBS-STUDY and CLASS-IN fields are quick-search criteria fields normally used by database personnel for extracting information for reports but can be used by any user to retrieve all the information on one study in a file. REF-CODE links the test data with the information sourco in the CERSOURC file. Specific field listings for each file are shown in Tables 2 though 9.

Lubricants perform an important function in wear testing. By coating the contact surfaces, the lubricant can have a considerable effect on the wear life of a material. Notes about lubricant breakdown, by-product effects on material surfaces, and other important details should be included with other information about the lubricant. The LUBRICANTS file contains base stock information, supplier name, upper temperature limit for normal operation, and comments on other characteristics of importance for each lubricant used in the tribology studies.

Data tables for this report are organized according to type of data: Appendix $A$ contains available background information on the materials presented in this report; Appendix $B$ contains the experimental text data arranged in sections by property type. Some test data listed in Appendix B may not be represented by materials in Appendix $A$ but will be included in a later report when such information becomes available. The policy for this database is to store the available information for future use, whether or not a complete set of information is available on a material. Complete sets are preferred and sought as time permits.

The dBASE IV program does not allow storage of superscripts or subscripts, so the numbers used in chemistries must be carefully coded. As a rule, the number or numbers immediately following a chemical abbreviation are subscripts. Numbers indicating multiple molecules are enclosed in parentheses. Alumina, $\mathrm{Al}_{2} \mathrm{O}_{3}$, would be coded as $\mathrm{Al} 2 \mathrm{O} 3$; mullite, $2 \mathrm{Al}_{2} \mathrm{O}_{3}+3 \mathrm{SiO}_{2}$, would be coded as (2)Al2O3+(3)SiO2. Superscripts, atthough rarely used in this database, are enclosed in backslashes: $\mathrm{Ne} 12$ would be $\mathrm{Nel} 121$. 


\section{SYSTEM ACCESS}

Direct access to the master database is very limited to protect the integrity of the master files. Experience has shown that major disasters often occur when too many people have direct access to unprotected files at the microcomputer level. Since most users would prefer to have the data in a familiar format, to subset, analyze, and rearrange to suit their needs, this method satisfies both situations; the master files are protected, and the user gets the data in a readily consumable form. While direct access is faster, the process of downloading across phone lines can be time consuming and hazardous to the integrity of the data being transmitted. This database was designed as a repository, not a full-function analytical tool.

Access to the data is attained by calling the database administrator and requesting all files or just those pertaining to certain materials or test types. The information requested by the user (in the userdesignated format, including software and disk type) will then be downloaded from the master files, reformatted, if necessary, and sent to the user when possible. No plans are being considered for direct access from outside systems at this time. Direct transfer is available by special arrangement but may be time consuming due to the sizes and numbers of files. No guarantee is given for the validity of data transmitted directly because of possible phone line problems. Until a computerized interface becomes available, the CTP Data Base User's Guide will be sent to all first-time users.

Several file formats, other than dBASE IV, are available for files downloaded for users. These formats have been categorized as either Apple Macintosh-compatible files (on 3.5-in. floppy disks), or IBM PC-compatible files (on 3.5-in. floppy disks up to $1.44 \mathrm{MB}$ or 5.25-in. floppy disks from $360 \mathrm{~KB}$ to $1.2 \mathrm{MB}$ ). Available Macintosh file types include Microsoft EXCEL; SYLK; FOXBASE; and plain, printable ASCII. IBM file types are Lotus 1-2-3, Microsoft EXCEL, DIF, SDF, SYLK, plain ASCII, delimited ASCII, and dBASE IV. Other formats may be available by special arrangement. When requesting information from the database, users should indicate disk size, disk density, and file type.

With computer diseases becoming so rampant, users should be aware that precautions are taken to ensure that the disks they receive from the database are disease free. Only new disks are used for transmittals to avoid spreading any computer diseases that might be hiding. No recycled, reformatted disks are sent to users. Both the master system, a Northgate Elegance 486/25, and the Macintosh Ilcx are checked regularly for such illnesses; none have been found so far. Use of both computers is limited to one person who carefully screens incoming software to avoid contamination of either system. No information is downloaded from public bulletin boards to either system. Both computers have virus detection software installed, and all efforts are made to ensure both systems stay disease free. If users have problems with disks received from the database, they should inform database personnel immediately so that steps can be taken to correct the problems. 


\section{FUtURE PLANS}

Many changes and additions to the database have been made over the past two years. Some of the changes were made only to a selected set of data because of time constraints. Database personnel plan to do catch-up work for the database during FY 1992.

Plans are being made to write a computerized user interface using the dBASE IV programming language and to have the initial version completed some time in 1992. The interface will link the numerous database files together, providing better access to information in the system. This interface will be available to all users of the database who request it.

The next hardcopy update is scheduled for September 1992.

\section{OTHER CTP DATABASE SUMMARY REPORTS}

M. K. Booker, Ceramics Technology for Advanced Heat Engines Project Data Base: A Summary Report, ORNLM-462, Martin Marietta Energy Systems, Inc., Oak Ridge Natl. Laboratory.

B. L. P. Booker, Ceramics Technology for Advanced Heat Engines Project Data Base: September 1988 Summary Report, ORNL/M-755, Martin Marietta Energy Systems, Inc., Oak Ridge Natl. Laboratory, March 1989.

B. L. P. Keyes, Ceramics Technology for Advanced Heat Engines Project Data Base: March 1989 Summary Report, ORNL/M-1098, Martin Marietta Energy Systems, Inc., Oak Ridge Natl. Laboratory, April 1990.

B. L. P. Keyes, Ceramics Technology for Advanced Heat Engines Project Database: September 1989 Summary Report, ORNL/M-1286, Martin Marietta Energy Systems, Inc., Oak Ridge Natl. Laboratory, October 1990.

B. L. P. Keyes, Ceramics Technology Project Data Base: March 1990 Summary Report, Martin Marietta Energy Systems, Inc., Oak Ridge Natl. Laboratory, in publication.

B. L. P. Keyes, Ceramics Technology Project Data Base: September 1990 Summary Report, Martin Marietta Energy Systems, Inc., Oak Ridge Natl. Laboratory, in publication. 


\section{ACKNOWLEDGMENTS}

The author thanks Peter Blau for his help on the Cameron-Plint machine sketch and for reviewing this document, David Stinton for his comments and suggestions, and the Metals and Ceramics Division Records Office for editing and preparing the final draft for publication (Kathy Spence and Mary Upton, respectively).

\section{REFERENCES}

1. Peter A. Gaydos, "Current Progress in Studies of Dynamic Contact of Ceramics for Advanced Heat Engines," pp. 309-18 in Proceedings of the Annual Automotive Technology Development Contractors' Coordination Meeting, Dearborn, Mich., October 22-25, 1990, SAE P-243, Society of Automotive Engineers, Warrendale, $\mathrm{Pa}$.

2. F. A. Kelley, M. H. Haselkorn, and C. D. Weiss, "Wear-Resistant Ceramic Coatings for Diesel Engine Components," pp. 261-72 in Proceedings of the Annual Automotive Technology Development Contractors' Coordination Meeting, Dearborn, Mich., October 22-25, 1990, SAE P-243, Society of Automotive Engineers, Warrendale, Pa.

3. M. G. S. Naylor, "Wear-Resistant Ceramic Coatings," pp. 273-82 in Proceedings of the Annual Automotive Technology Development Contractors' Coordination Meeting, Dearborn, Mich., October 22-25, 1990, SAE P-243, Society of Automotive Engineers, Warrendale, Pa. 

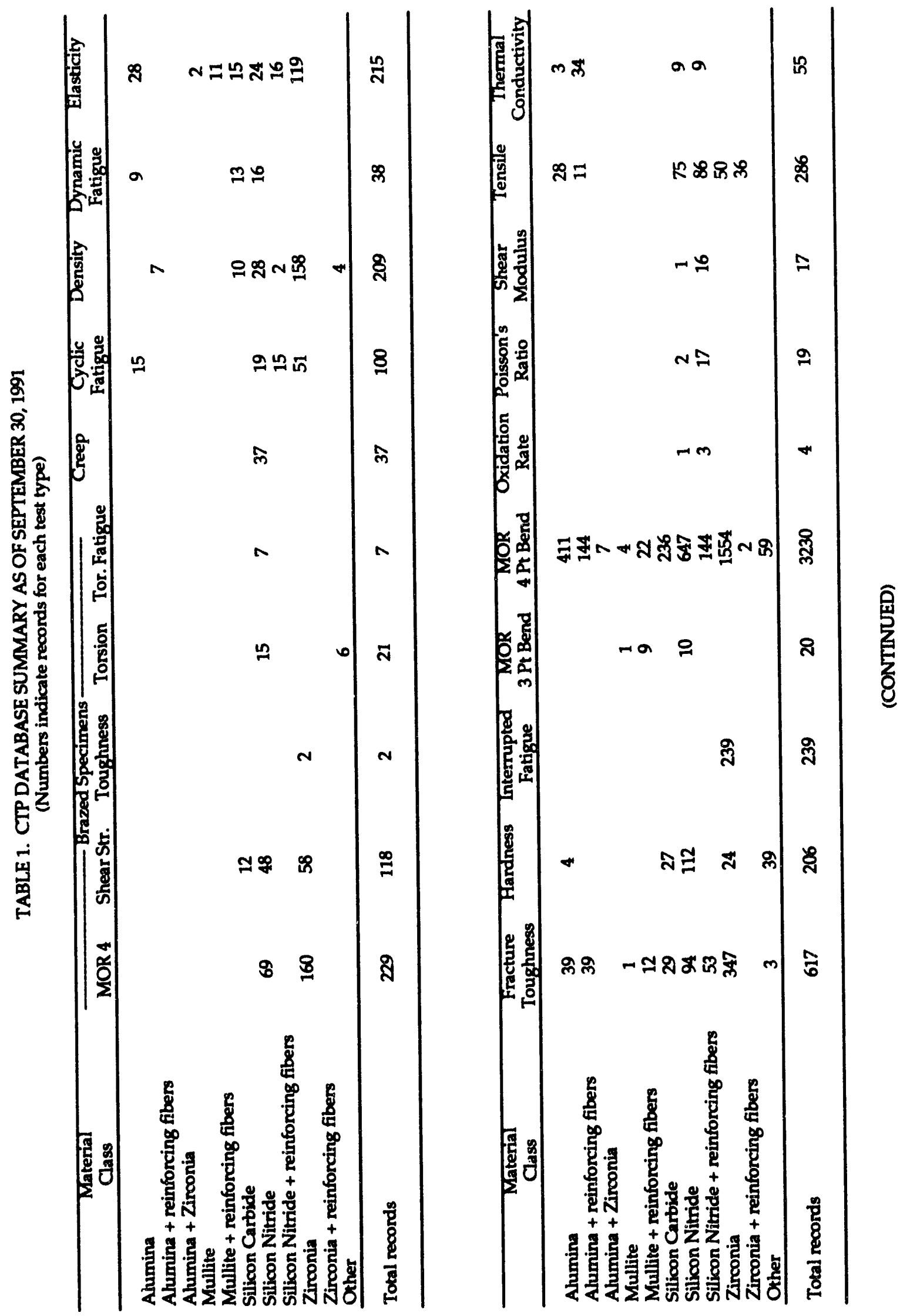


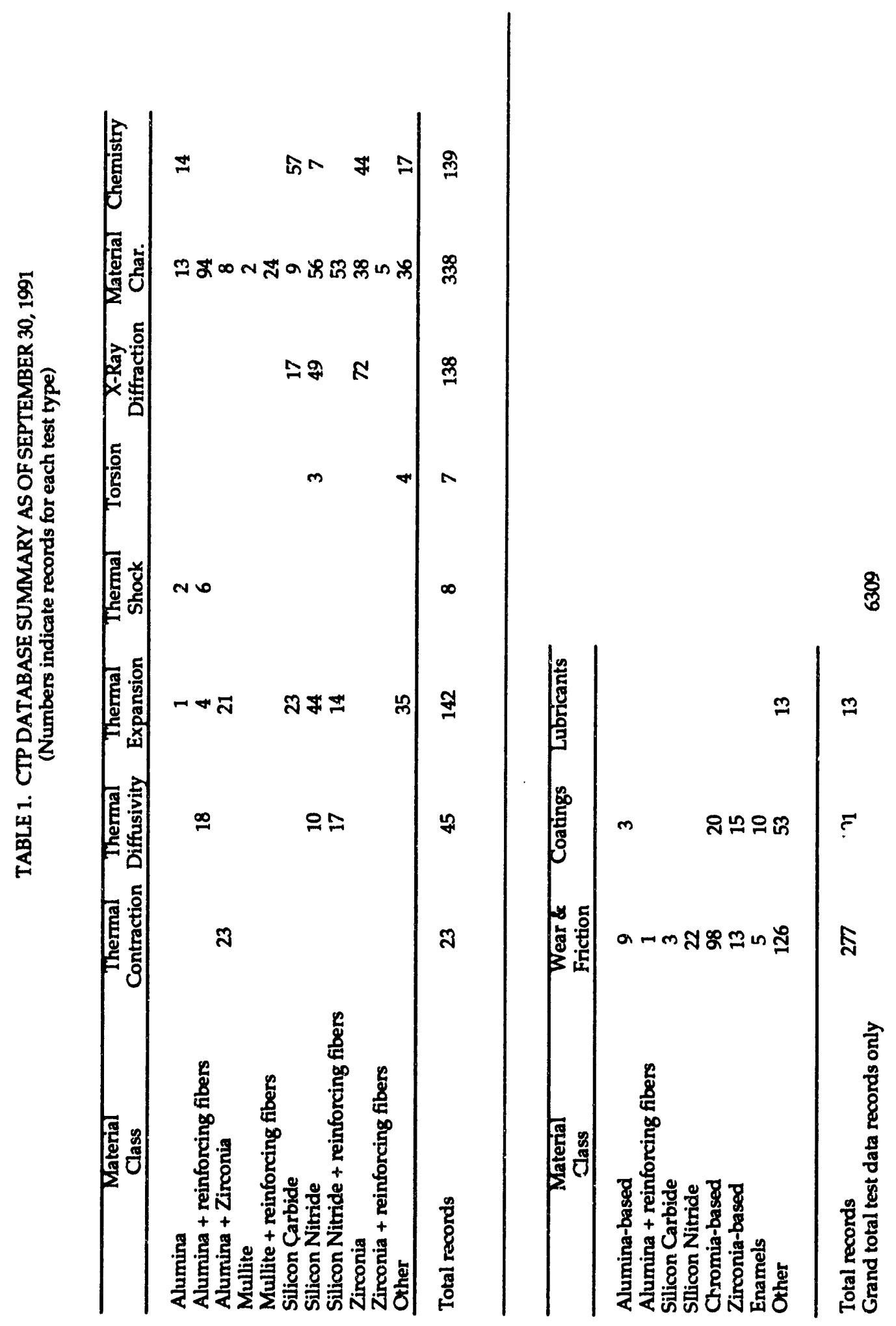




\section{TABLE 2}

\section{WEARDATA File Record Format \\ Wear Test Results}

\begin{tabular}{ll} 
Field Name & \multicolumn{1}{c}{ Description } \\
WBS_STUDY & Code made up of the CTP WBS number and responsible facility \\
TEST_ID & If present, a code denoting this test from all others \\
SPEC_ID & Specimen identification code \\
REF_CODE & Source of this information \\
COATING_1 & Coating material for mobile specimen \\
BATCHID_C1 & Batch code for COATING_1 \\
SUBSTRAT_1 & Substrate material for mobile specimen \\
BATCHID_S1 & Batch code for SUBSTRAT_1 \\
COATING_2 & Coating material for stationary specimen \\
BATCHID_C2 & Batch code for COATING_2 \\
SUBSTRAT_2 & Substrate material for stationary specimen \\
BATCHID_S2 & Batch code for SUBSTRATE_2 \\
LUBRICANT & Substance used to oil the contact surfaces in a test \\
TEST_RIG & Designation of the type of test apparatus used \\
DATA_CLASS & Type of data: TEST, AVG, NOM, TRGT \\
TEMP_C & Test temperature in centigrade \\
ENVIRONMNT & Atmosphere surrounding the specimens during testing \\
LOAD_N & Force placed on one surface normal to the other surface \\
COF_RANGE & Range of the coefficients of friction for the entire test \\
WEARUNITS & Units for WEARCOEF_1 and WEARCOEF_2 \\
WEARCOEF_1 & Calculated wear coefficient for the mobile specimen \\
WEARCOEF_2 & Calculated wear coefficient for the stationery specimen \\
DURATN_MIN & Duration of the total test in minutes, including break-in period \\
SPEED & Speed of the mobile specimen, units shown with value \\
SEETEXT & A logical field indicating existence of more comments in DATATXT file \\
COMMENTS & A field for brief notes \\
&
\end{tabular}


TABLE 3

\section{COATINGS File Record Format \\ Coating Characterization Information}

Field Name COATING

BATCH_ID

MAT_CLASS

MATRIX

APPLY_TYPE

OTHERNAME

THICKNESS

WBS_STUDY

REF_CODE

TEXTUF

COMMENTS

\section{Description}

Name of the coating as used in the database

Batch code for this specific coating

Type of coating: CERAMIC, CERMET, or METAL

Chemical composition of the basic material

Method used to apply the coating to the substrate

Other names used for this coating

Average thickness for this coating applied this way

Code made up of the CTP WBS number and responsible facility

Source of this information

A logical field indicating that more information is available in the

TEXTUF file, if the value is positive

Brief notes on this material

\section{TABLE 4}

\section{LUBRICNT File Record Format}

Lubricant Background Information

Field Name Description

LUBRICANT

FABRICATOR

BASE

MAX_TEMP_C

TEXTUF

WBS_STUDY

REF_CODE

COMMENTS
Name given to lubricant as used in the database

The company producing the lubricant

The basic substance for this lubricant, such as mineral oil, polyalpha-olefin

Maximum operating temperature, in centigrade, for this lubricant

A logical field indicating that more information is available in the

TEXTUF file, if the value is positive

Code made up of the CTP WBS number and responsible facility

Source of this information

Brief notes on this lubricant 


\title{
TABLE 5
}

\author{
MATLCHAR File Record Format \\ Material Characteristics Information
}

Field Name

MATERIAL

MAT_CLASS

BATCH_ID

CLASS_IN

WBS_STUDY

FABRICATOR

FAB_NAME

VINTAGE

MATRIX

ADDITIVES

DENSIFY

DENSTY_GCC

THDENS_PCT

MOE_MPA

MOR_MPA

TYPE_HARD

HARDNESS

THERM_EXP

COEF_FRICT

POISSONS

TYPE_KIC

KIC_MPAM

REF_CODE
Description

Name of material as used in the database

Classification of material based on its primary matrix: PSZ, SIN, SIC, ALO

Batch code for $\because$ is specific material

Class code used by database personnel for extracting data for reports

Code made up of the CTP waS number and responsible facility

Company producing the material

Producing company's name for the material

Date material was made

Primary compound or chemicals in a material

Enhancers added tc the primary matrix

Process used to increase density of the material, if ceramic

Density of the material, in grams/cubic centimeter

Theoretical density, expressed as a percentage

Young's modulus at room temperature, in gigapascals

Rupture strength at room temperature, in megapascals

Type of hardness test used for HARDNESS value

Value for hardness using type of test indicated in TYPE_HARD

Coefficient of thermal expansion, in $1 \times 10^{-6} /{ }^{\circ} \mathrm{C}$

Coefficient of friction

Poisson's ratio for this material

Type of toughness test used to produce KIC_MPAM value $\left(K_{I_{c}}\right)$

Fracture toughness $\left(K_{I C}\right)$, in $M P a / m$

Source of this information 


\section{TABLE 6}

\section{CHEMSTRY File Record Format \\ Chemical Compositions}

Field Name

MATERIAL

BATCH_ID

CLASS_IN

REF_CODE

WBS_STUDY

ANALYSIS

CONDITION

UNITS

CHEM_INFO

TEXTUF

COMMENTS
Description

Name of material as used in the database

Batch code for this specific material

Class code used by dtabase personnel for extracting data for reports

Source of this information

Code made up of the CTP WBS number and responsible facility

Type of analysis performed

Processing state material was in at time of analysis

Units used for the quantities in the CHEM_INFO field

Chemistry information as element: quantity, eg. Al:20.0, Si:10.3, C:3.9.

A logical field that, if positive, indicates more information is

available in the text file TEXTUF for this material and batch code.

Brief notes on the chemistry of this material

\section{TABLE 7}

\section{TESTBKGD File Record Format \\ Test Background Information}

Field Name

TEST_RIG

TEST_TYPE

REF_CODE

SEQ

TEST_BKGD
Description

Name or designation given to testing apparatus as used in the database

Name of the test data file containing the data that was run on this test rig;

for example, WEARDATA.

Information source

Sequence number for one line of text in a single test rig description

The field that contains the actual text information. Each test rig description may have one or as many records as needed to describe completely the test procedures, equipment, or other noteworthy details. 


\section{TABLE 8}

\section{DATATXT File Record Format \\ Extended Comments for Specific Test Results}

Field Name MATERIAL

BATCH_ID

CLASS_IN

WBS_STUDY

TEST_TYPE

SPEC_ID

SEQ

TEXT
Description

Name of the material tested

Batch code or lot number for the material

Class code used by database personnel for extracting data for reports

Code made up of the CTP WBS number and responsible facility

Name of the test data file containing the data that was run on this test rig;

for example, WEARDATA.

Identification code for the sample referred to in the following TEXT field

Sequence number for one line of text for a single set of notes

The field that contains the actual text information. Each set of notes per

individual test may have as many of these records as needed to store the information.

TABLE 9

\section{MATNAMES File Record Format Thesaurus of Material Names}

Field Name

MATERIAL

MAT_TYPE

NAME_CHEM

NAME_COMM

NAME_OTHER
Description

Name of the material tested

General type of material (eg. ceramic, cermet, braze, metal, etc.)

Name of material based on its chemistry (eg. Cr2O3-5\%SiO2-3\%TiO2 for M136)

Name of material as assigned by the manufacturer (eg. ARTUFF for $\mathrm{Al}_{2} \mathrm{O}_{3}+\mathrm{SiCW}$ )

Names that may be assigned to this material other than those already listed. 


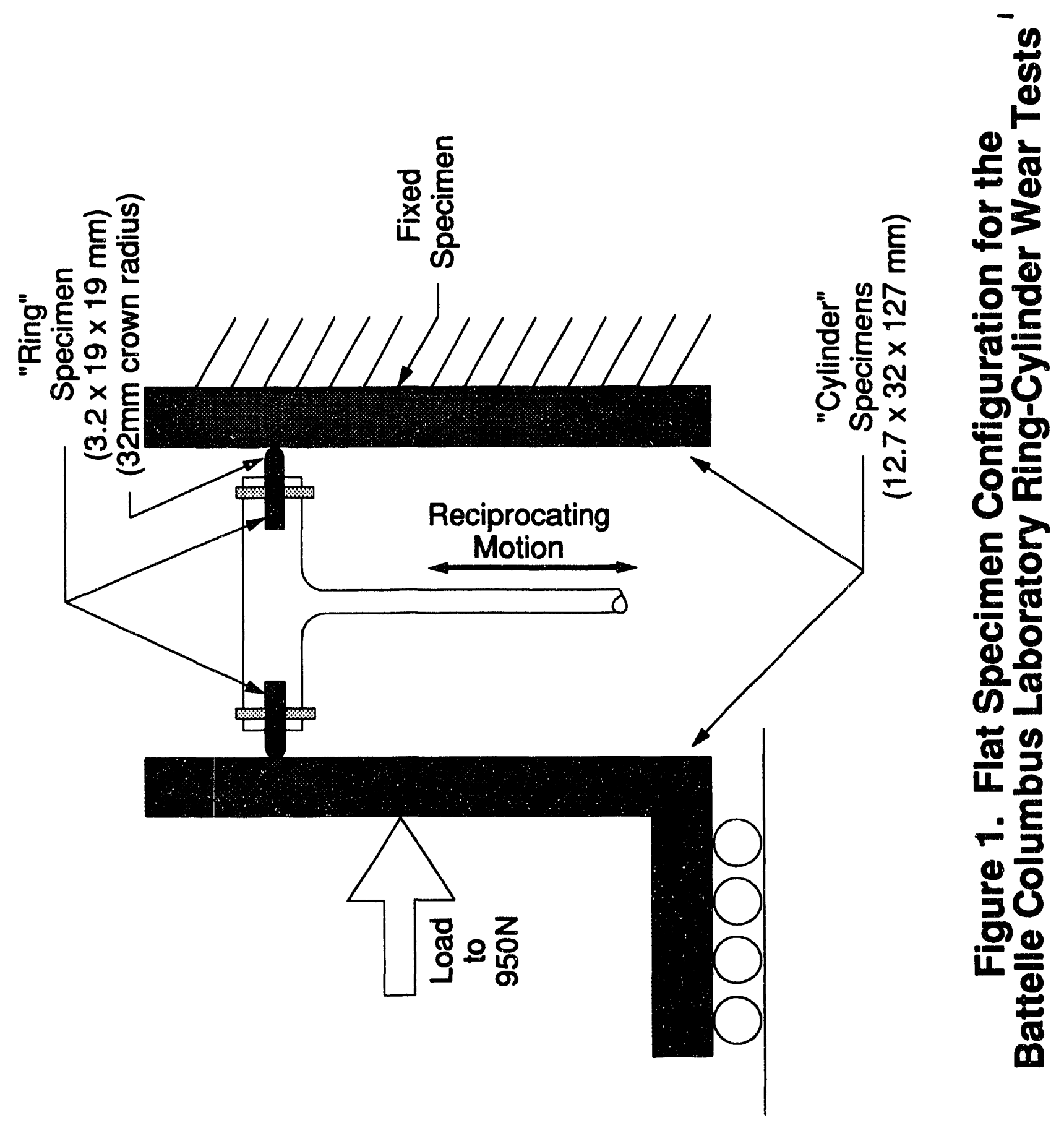




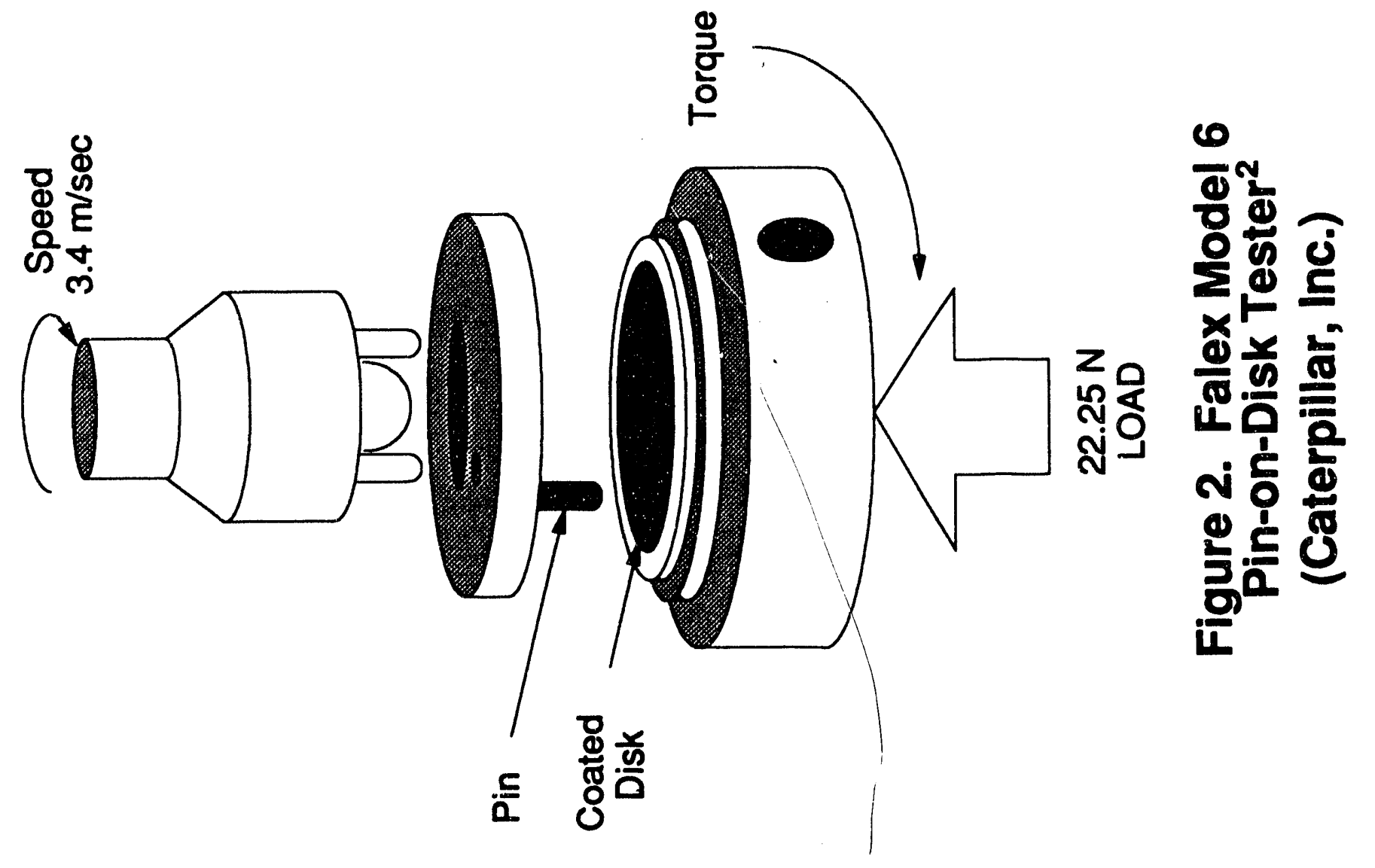




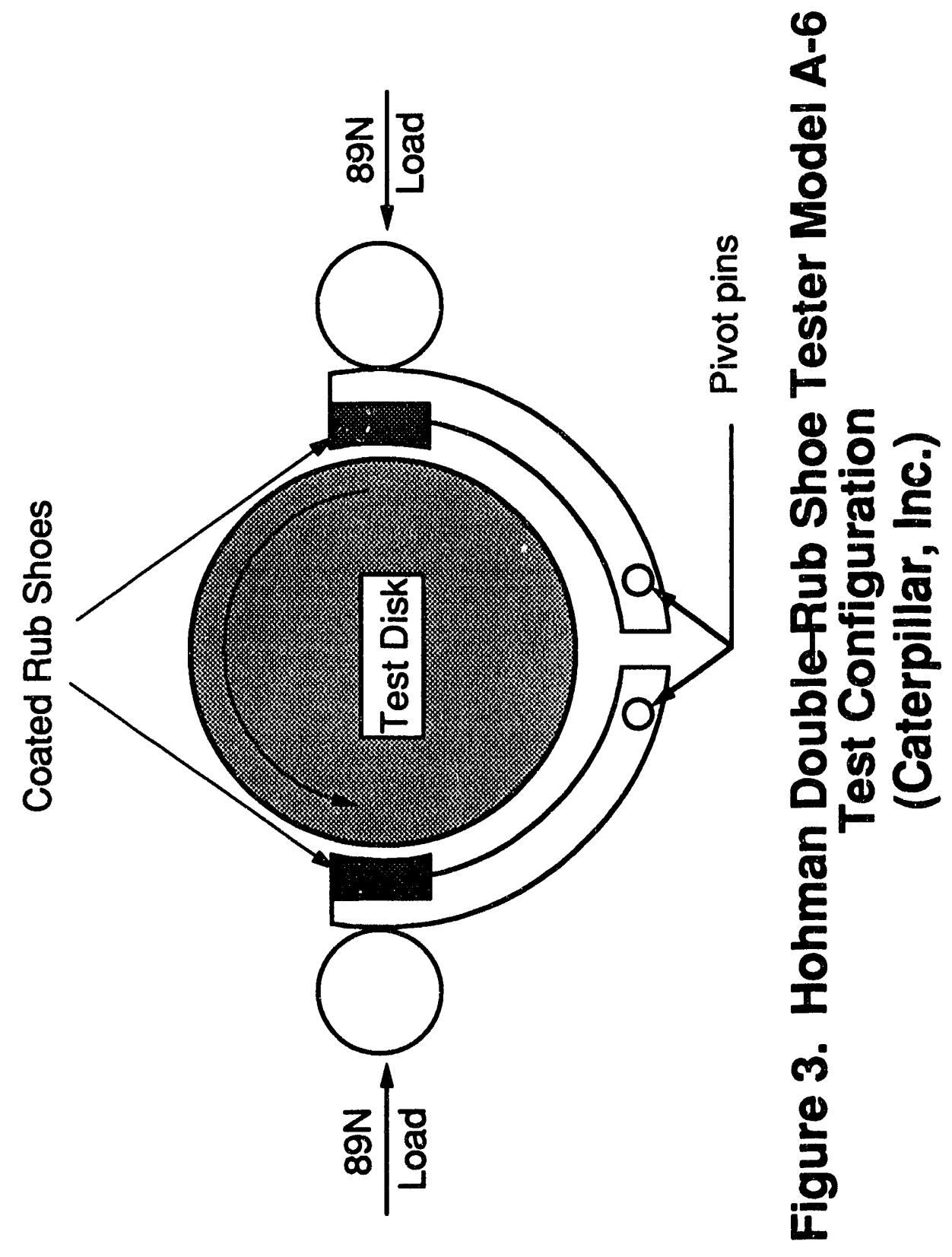




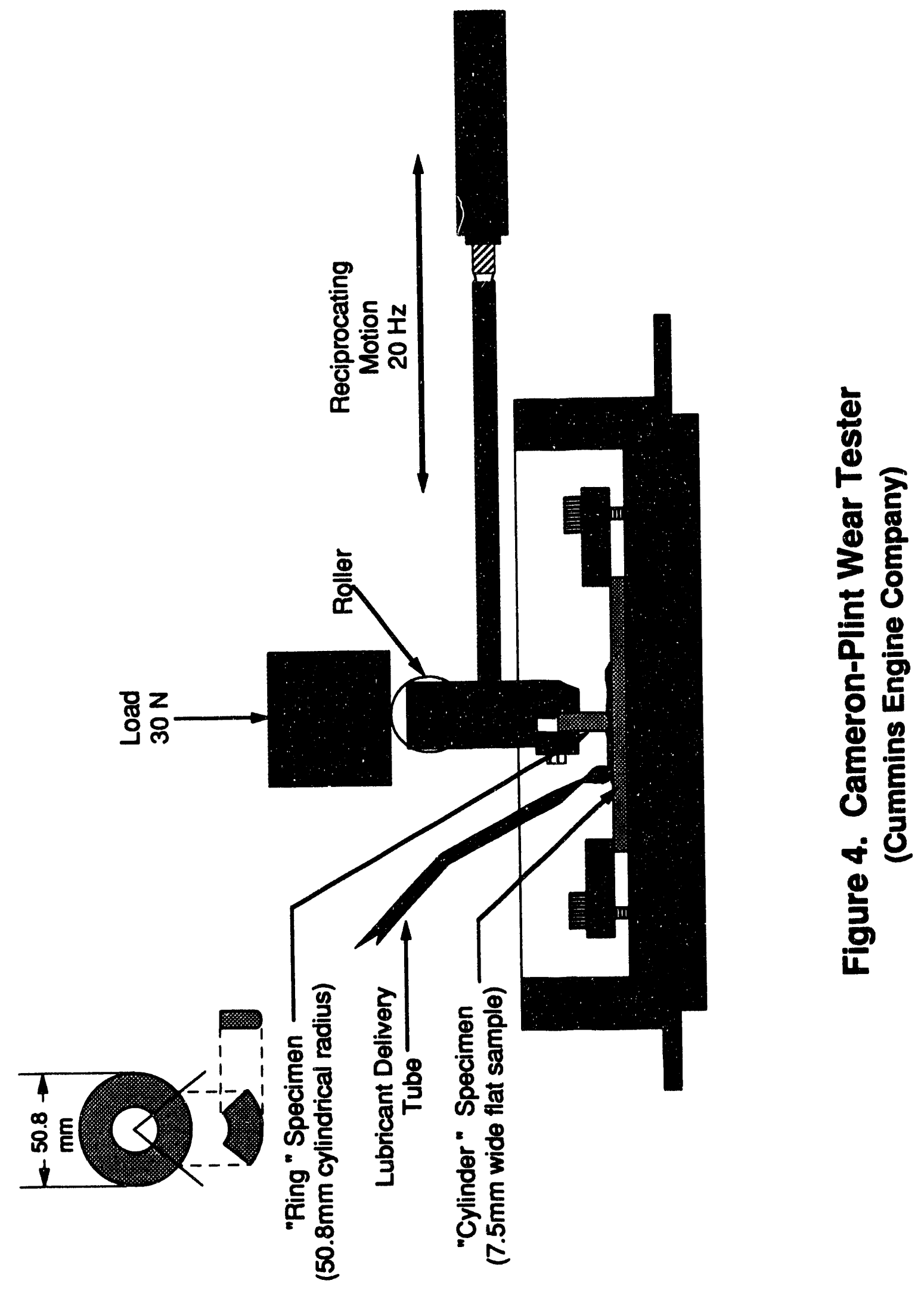




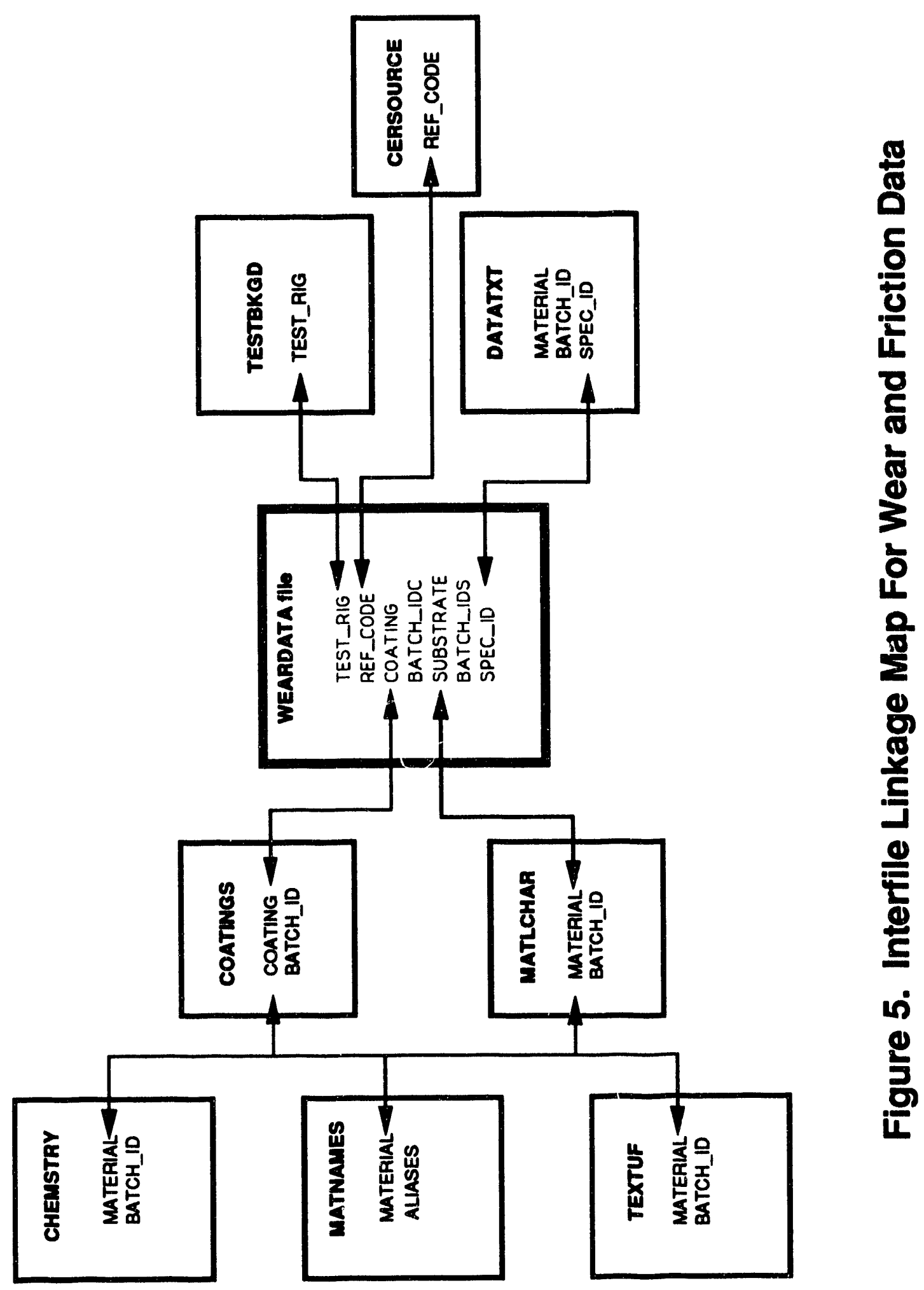


APPENDIX A. MATERIAL CHARACTERISTICS AND BACKGROUND DATA 


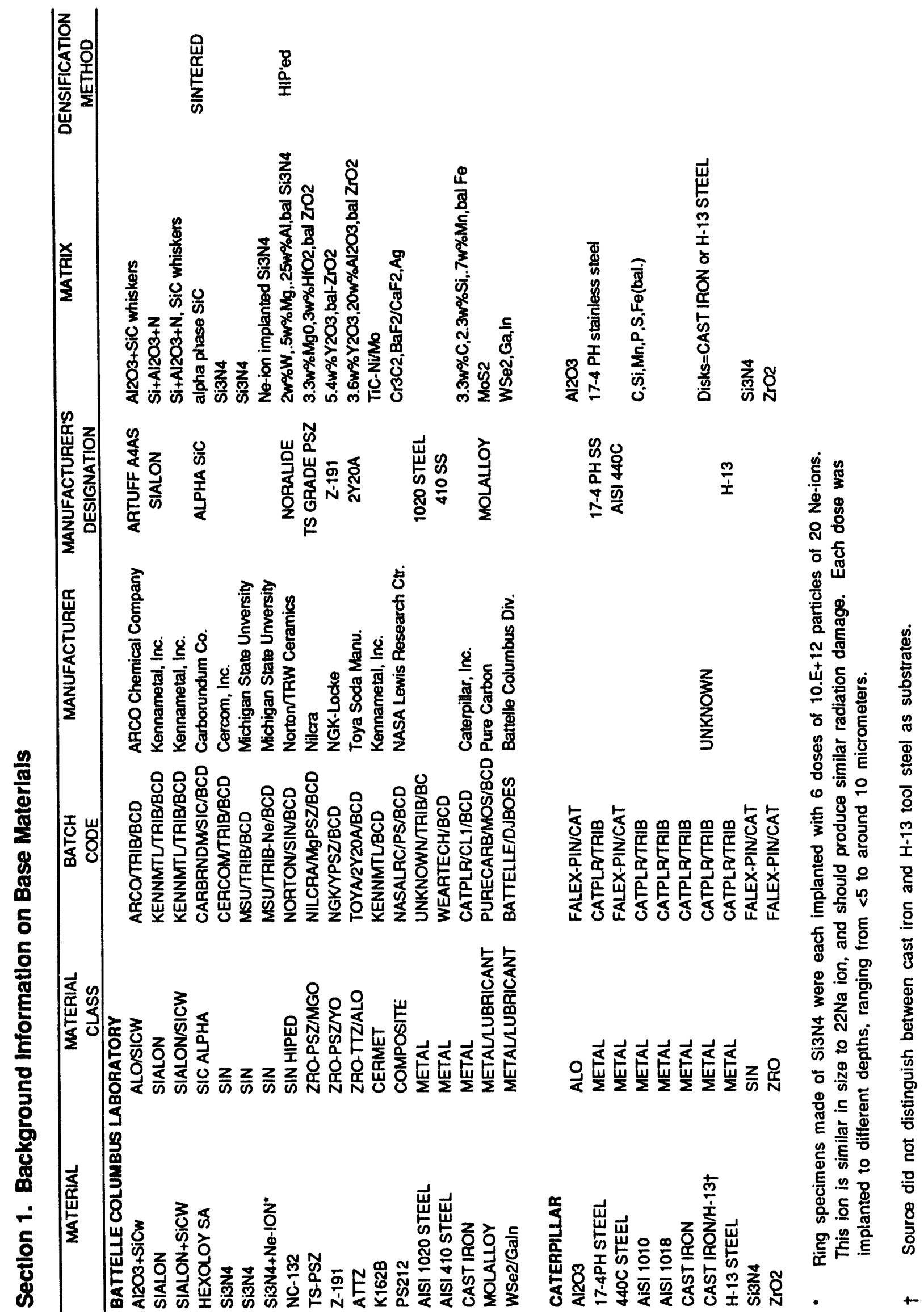




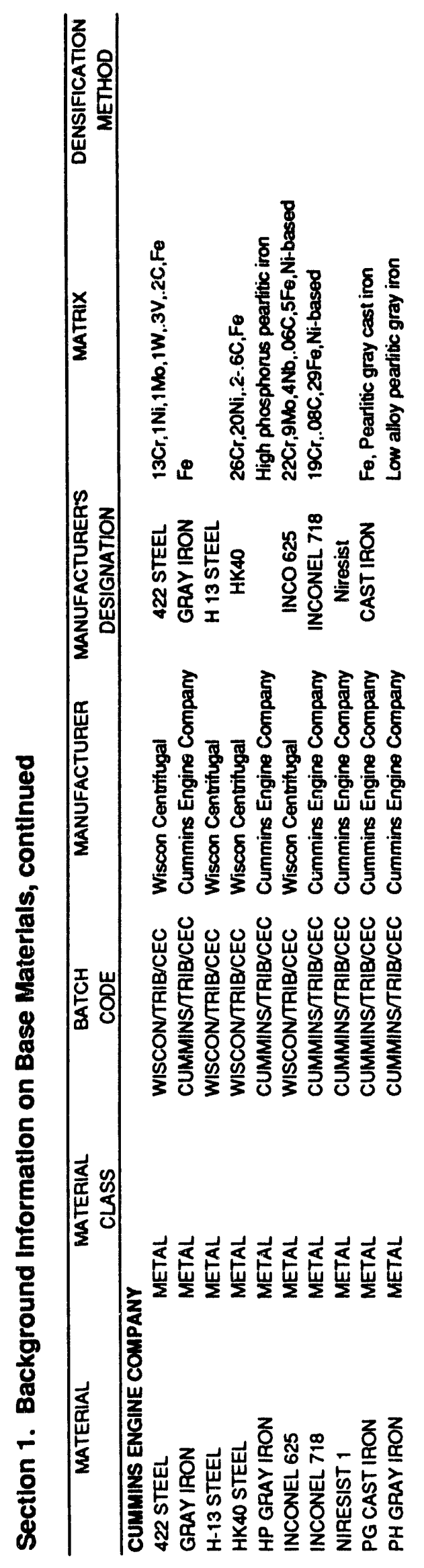




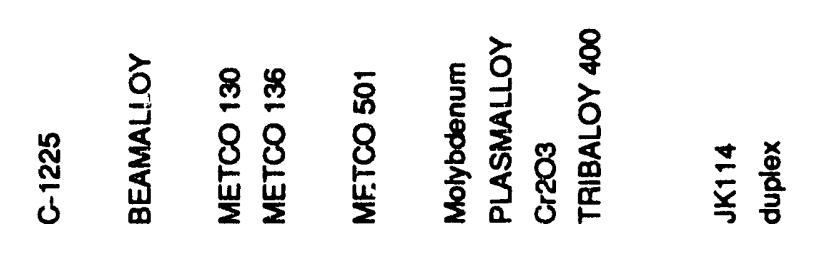

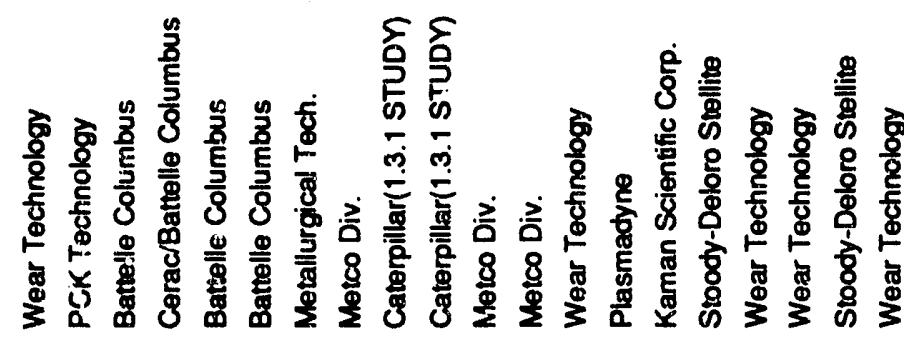

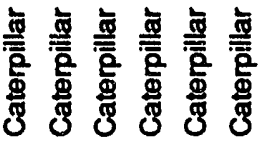

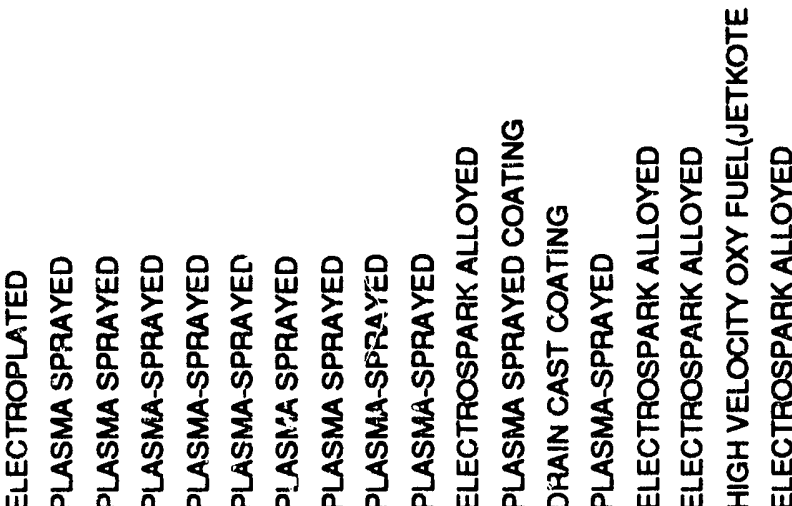

然

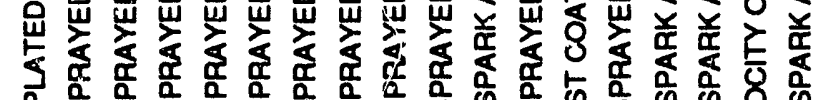

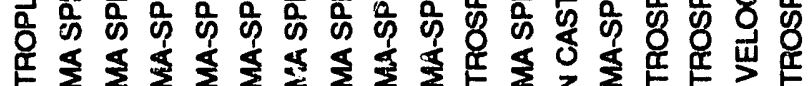

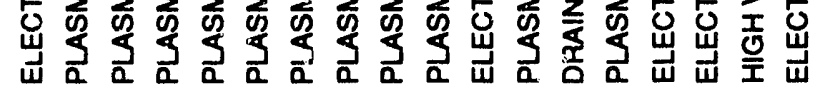

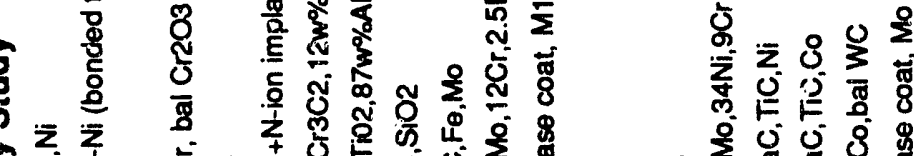

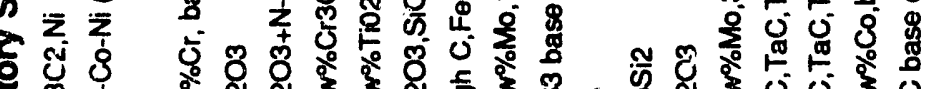

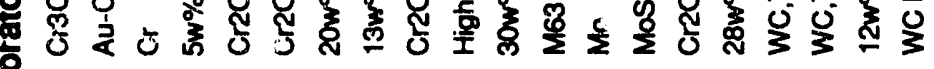

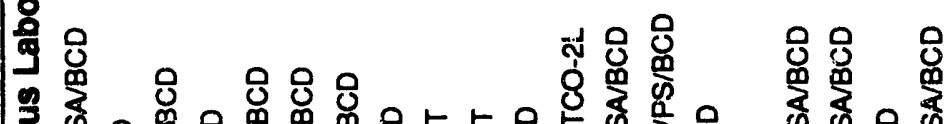

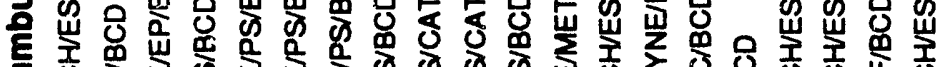

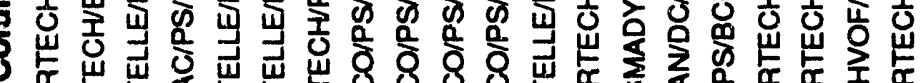

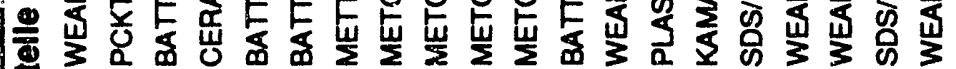
ए

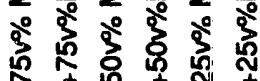

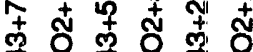
象东东名 \& o 8 ơ 8

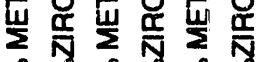

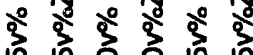

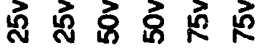




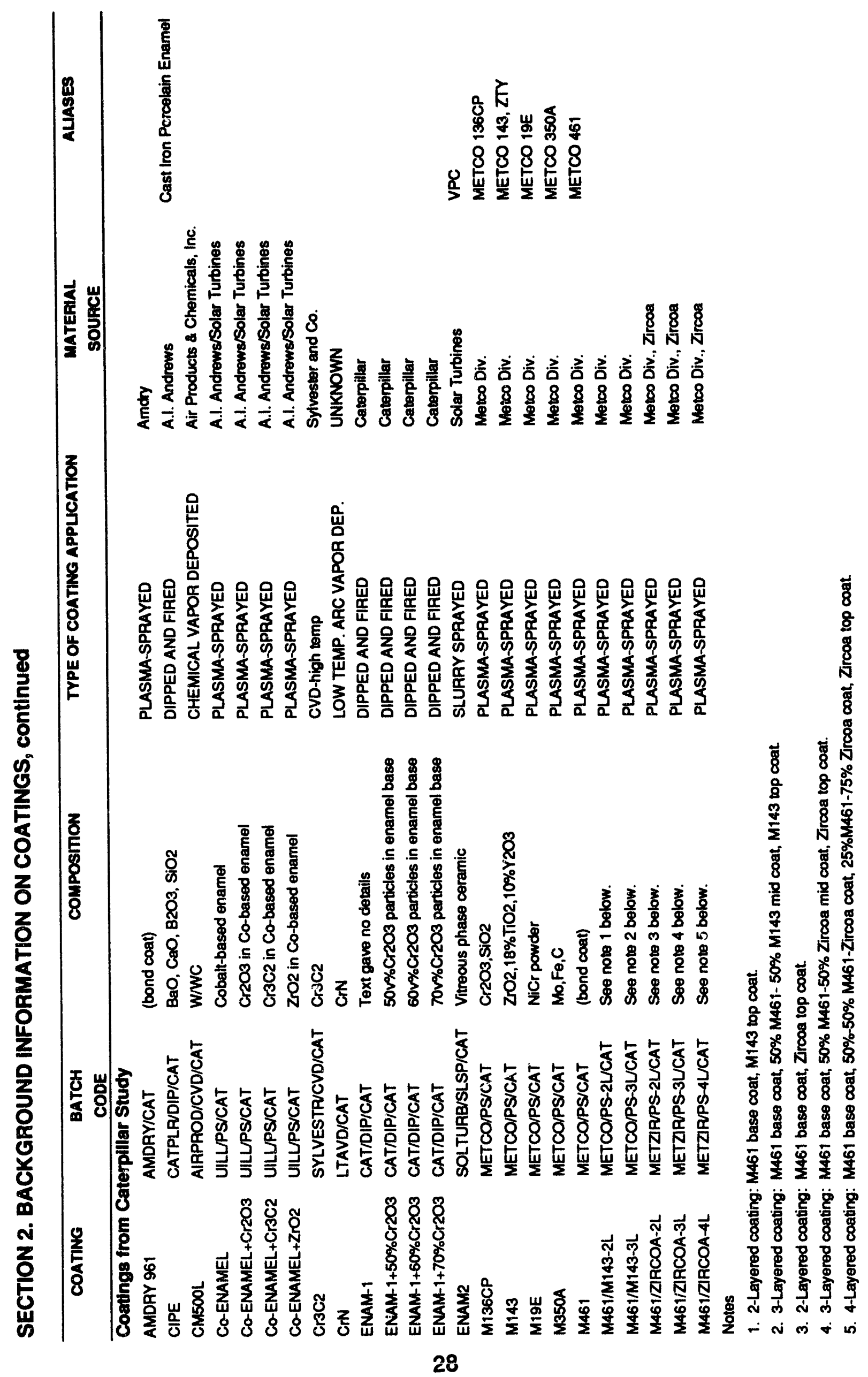




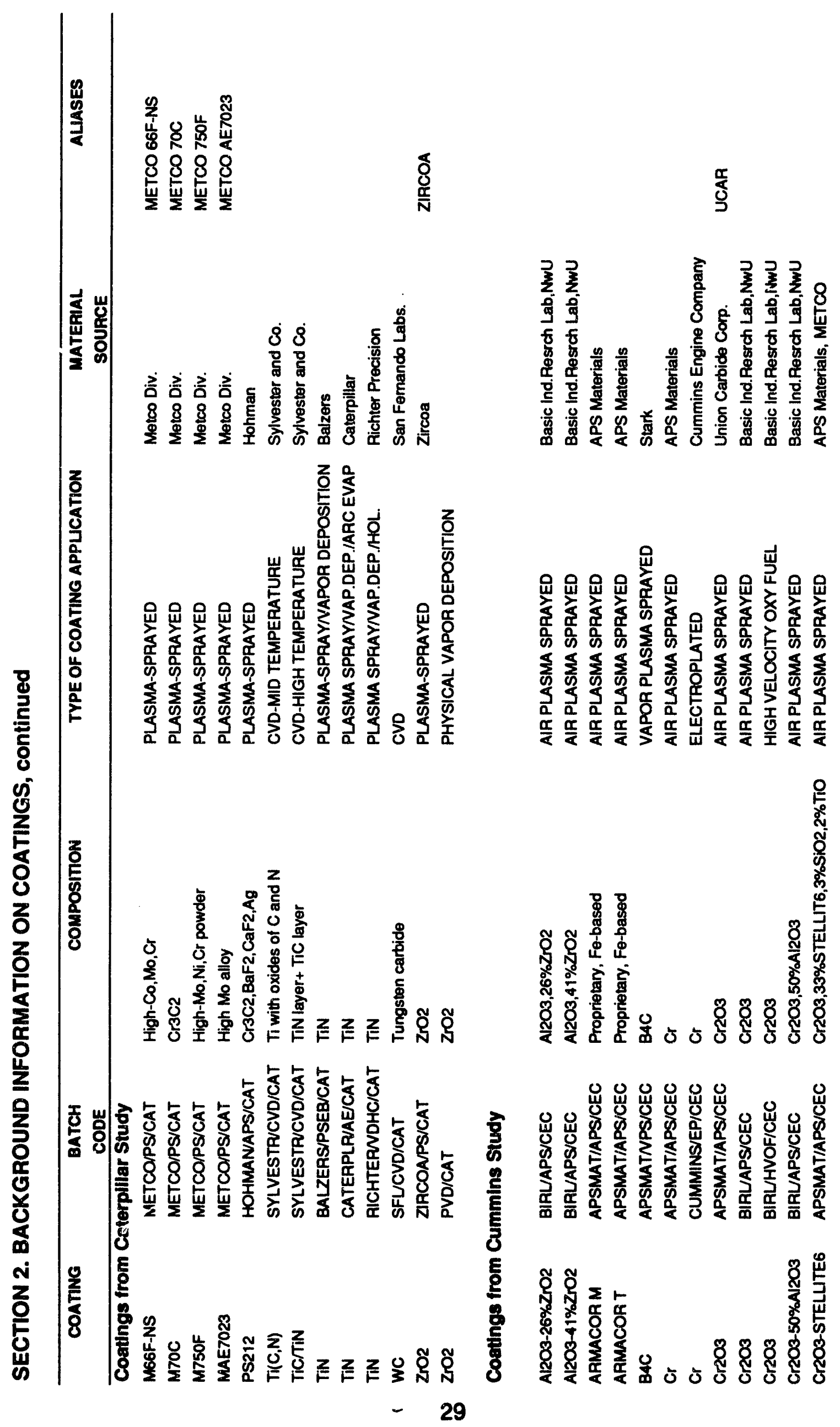




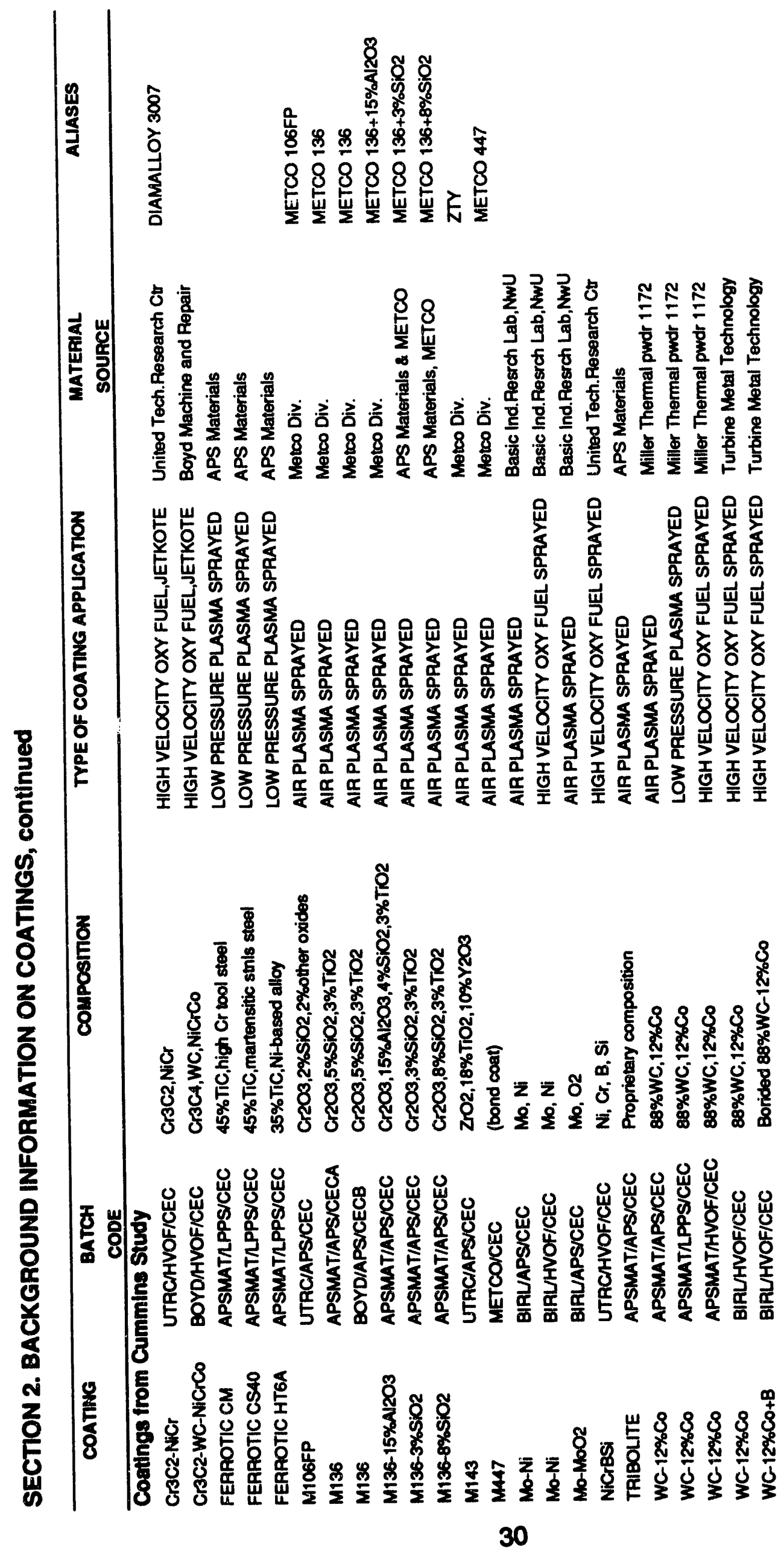




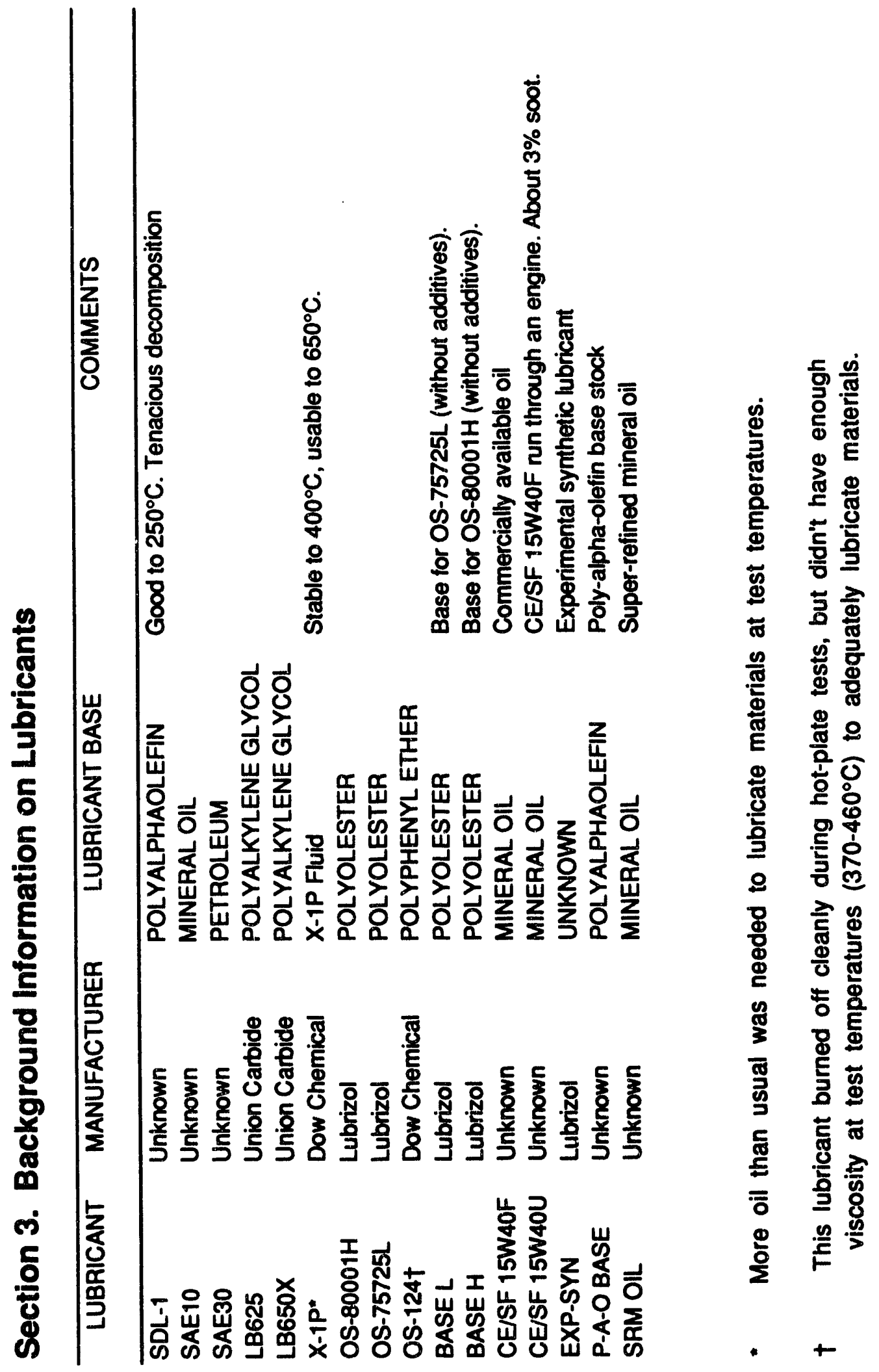




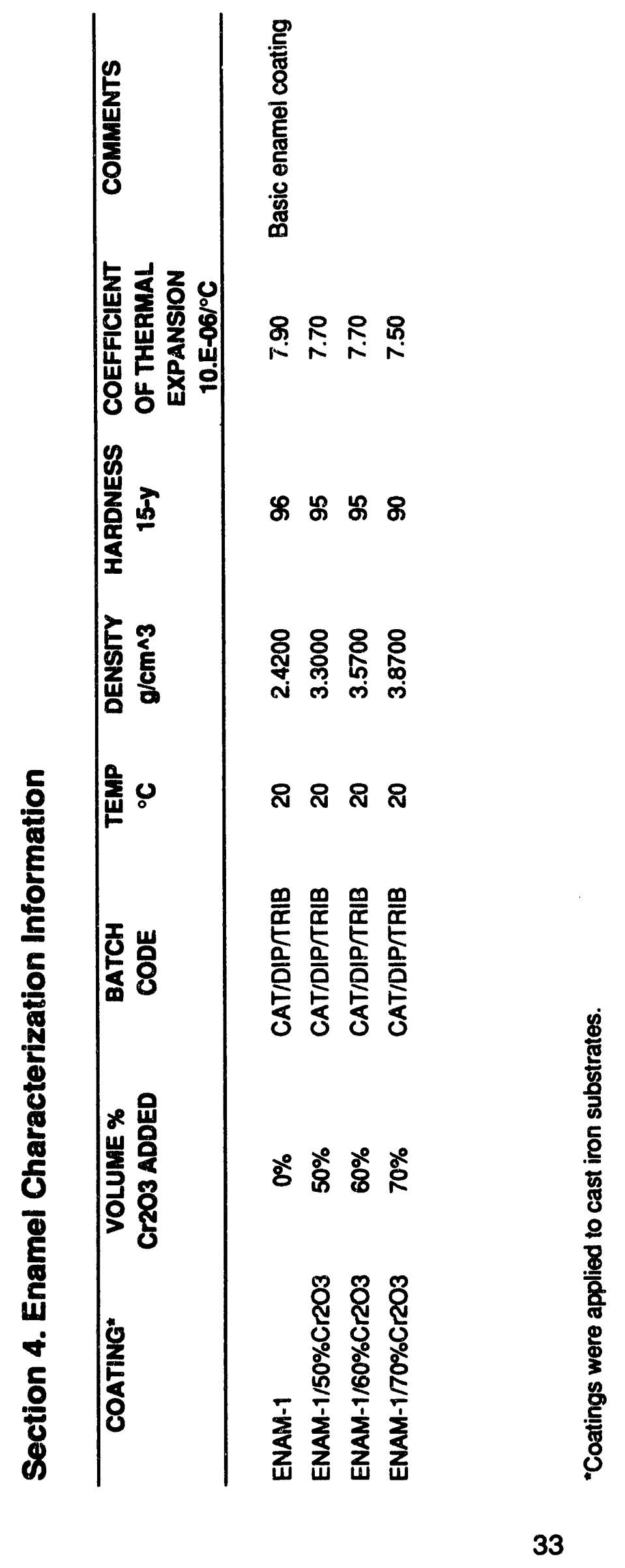




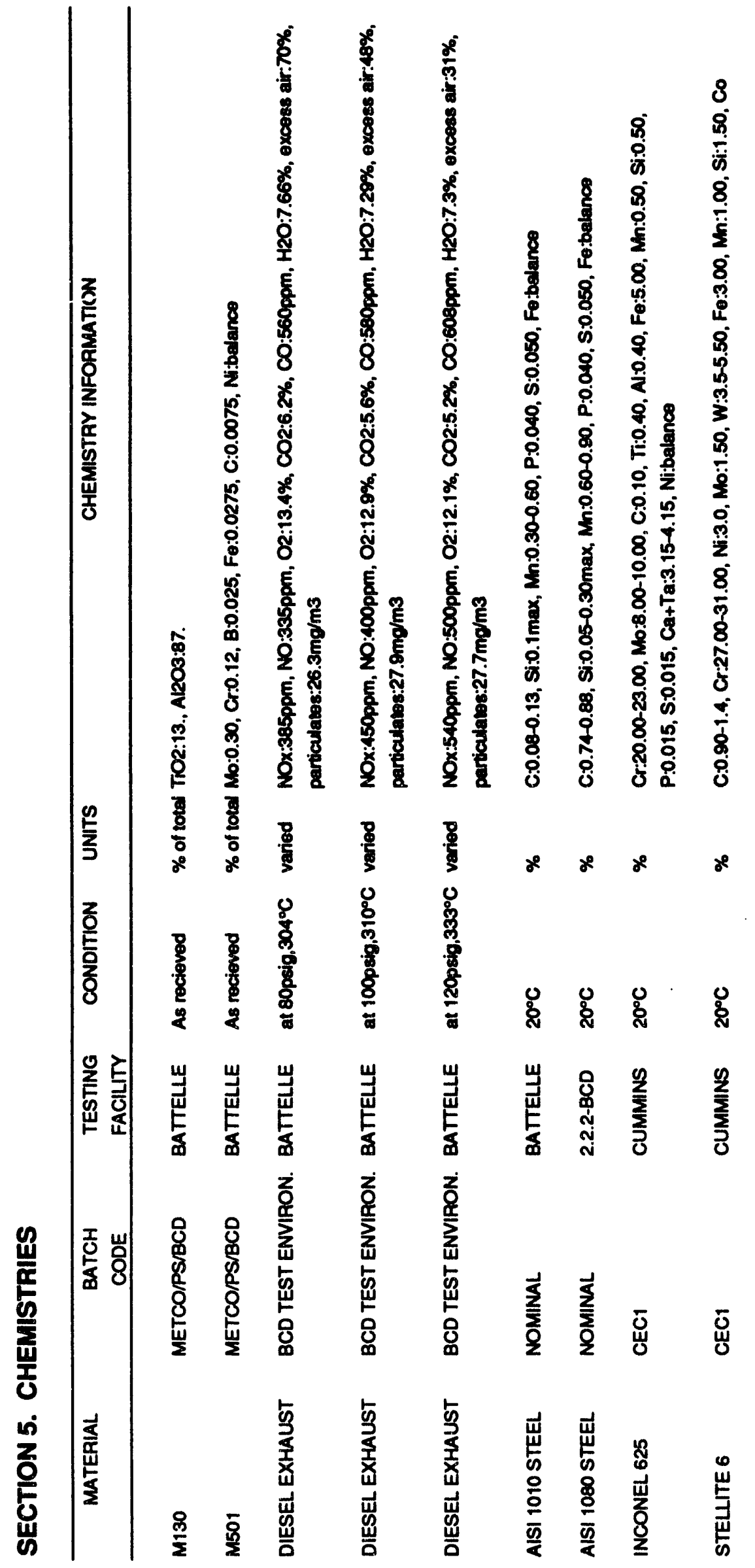


APPENDIX B. TEST RESULTS 


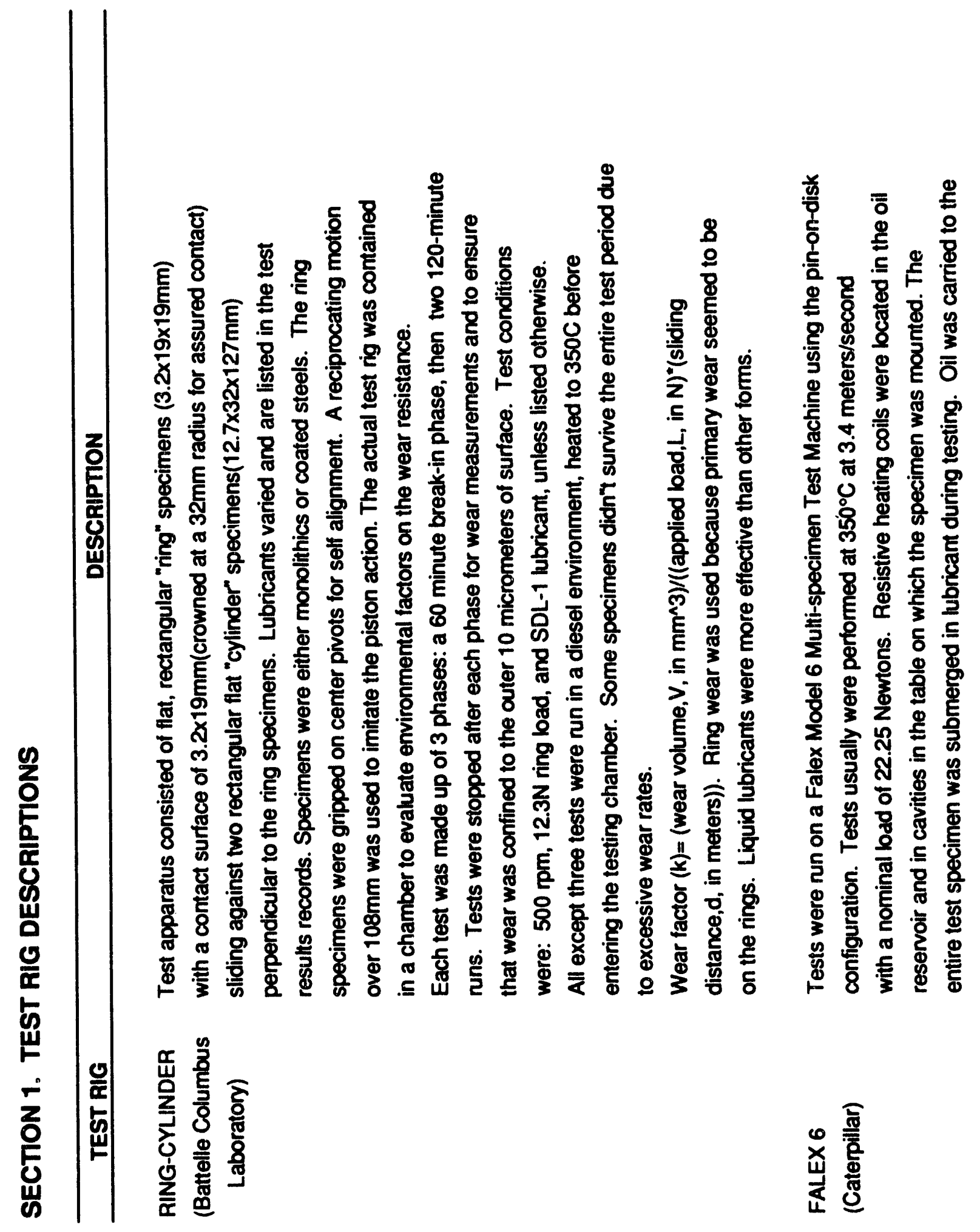




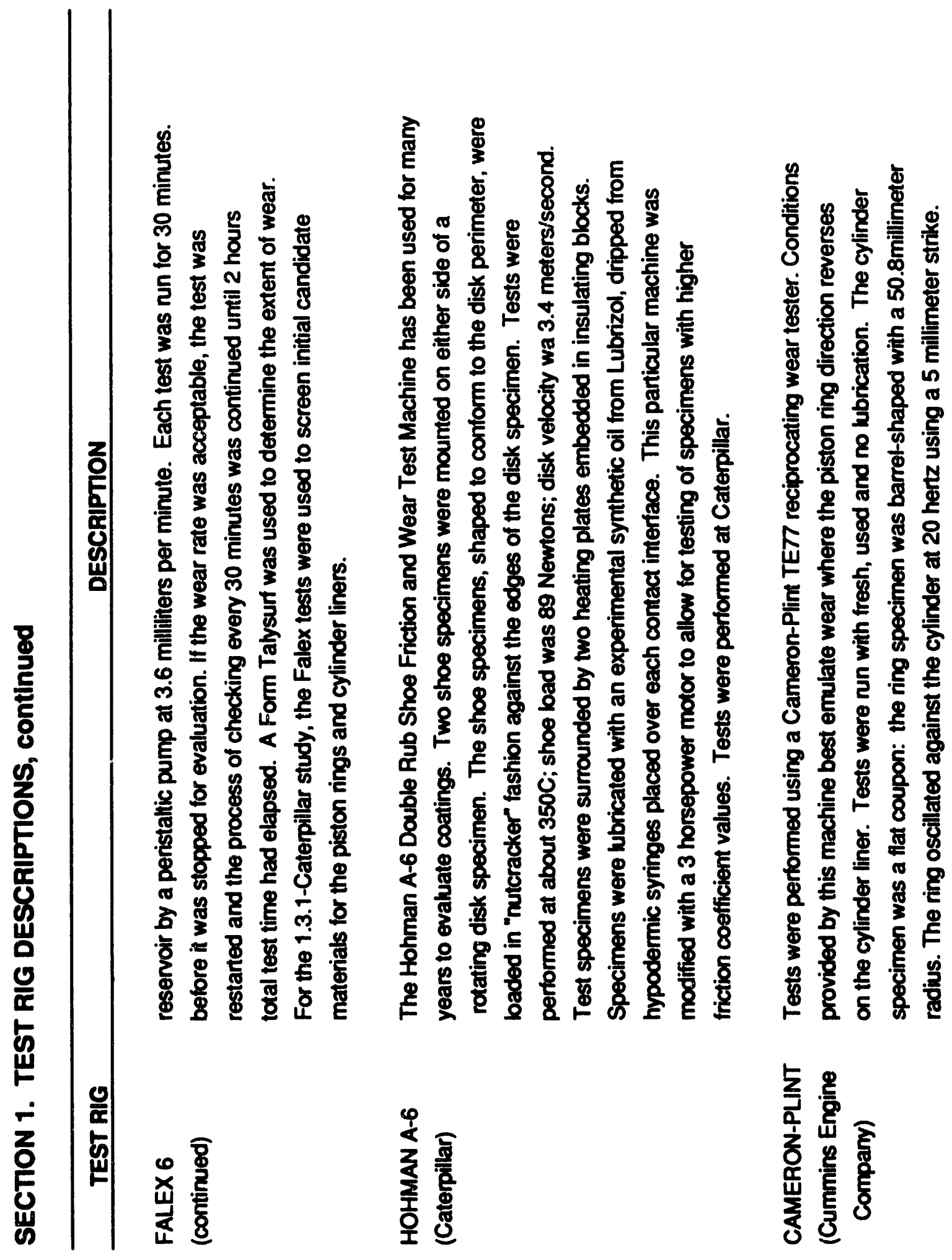




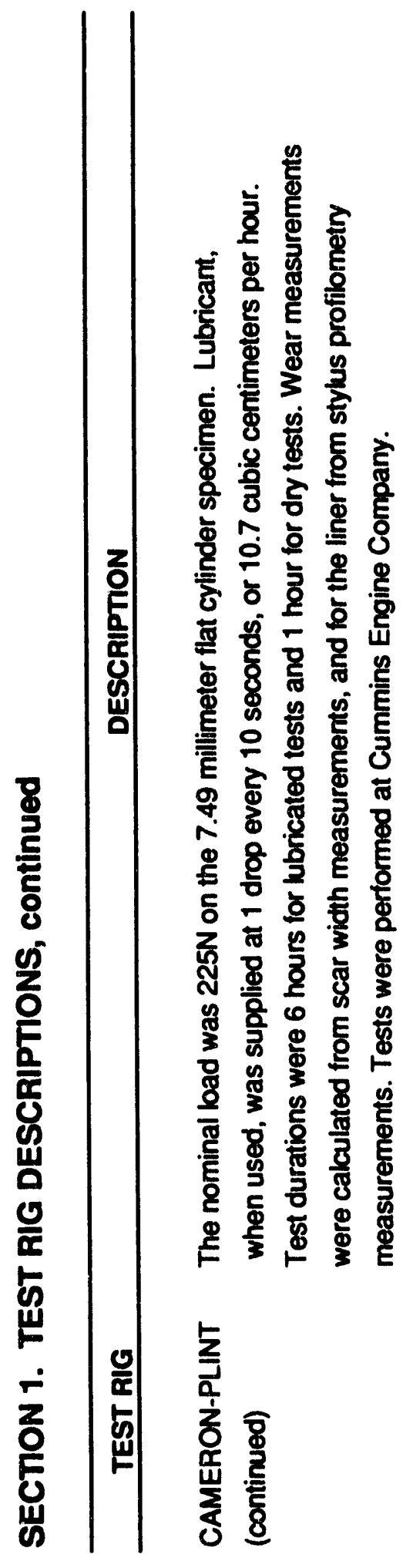




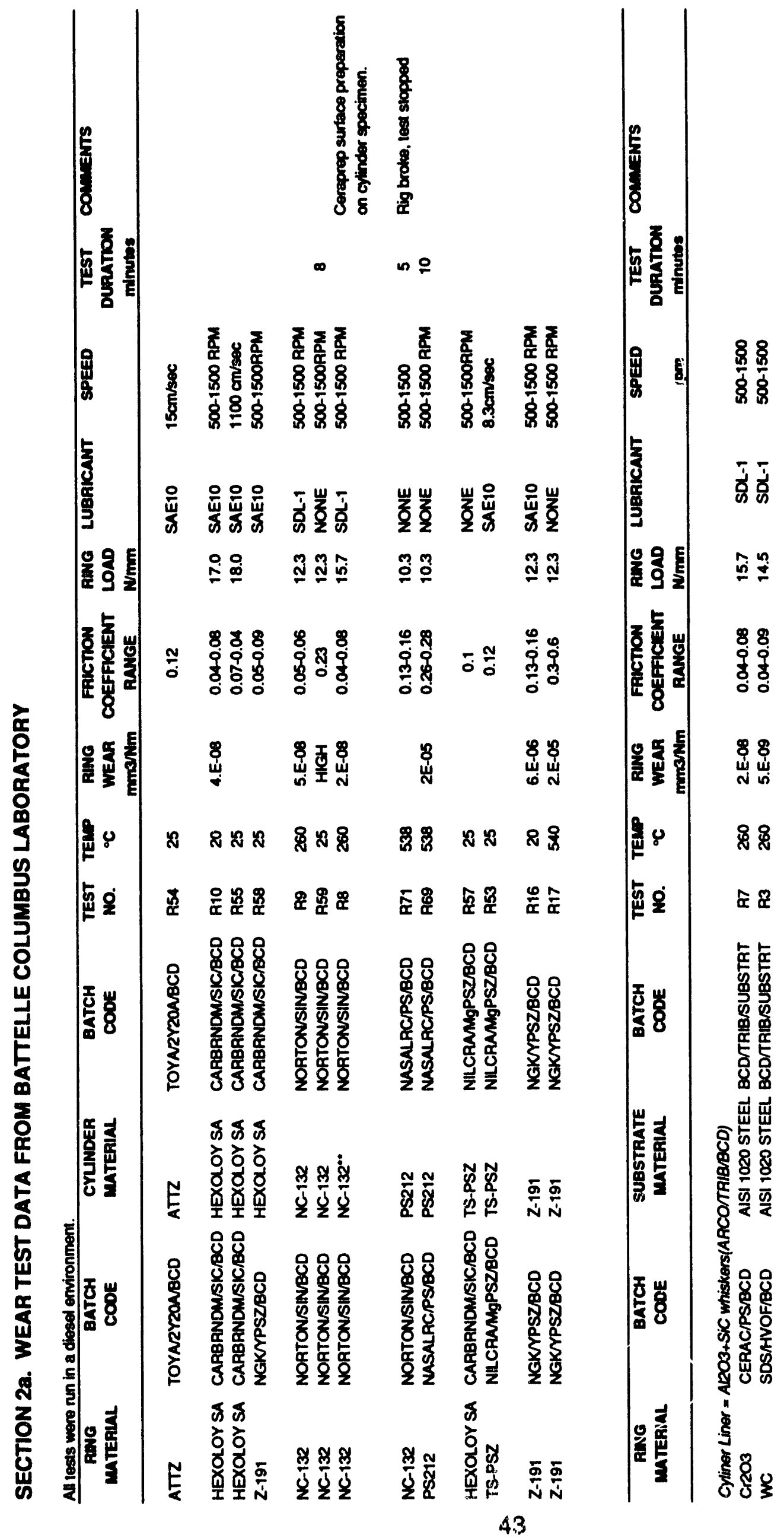




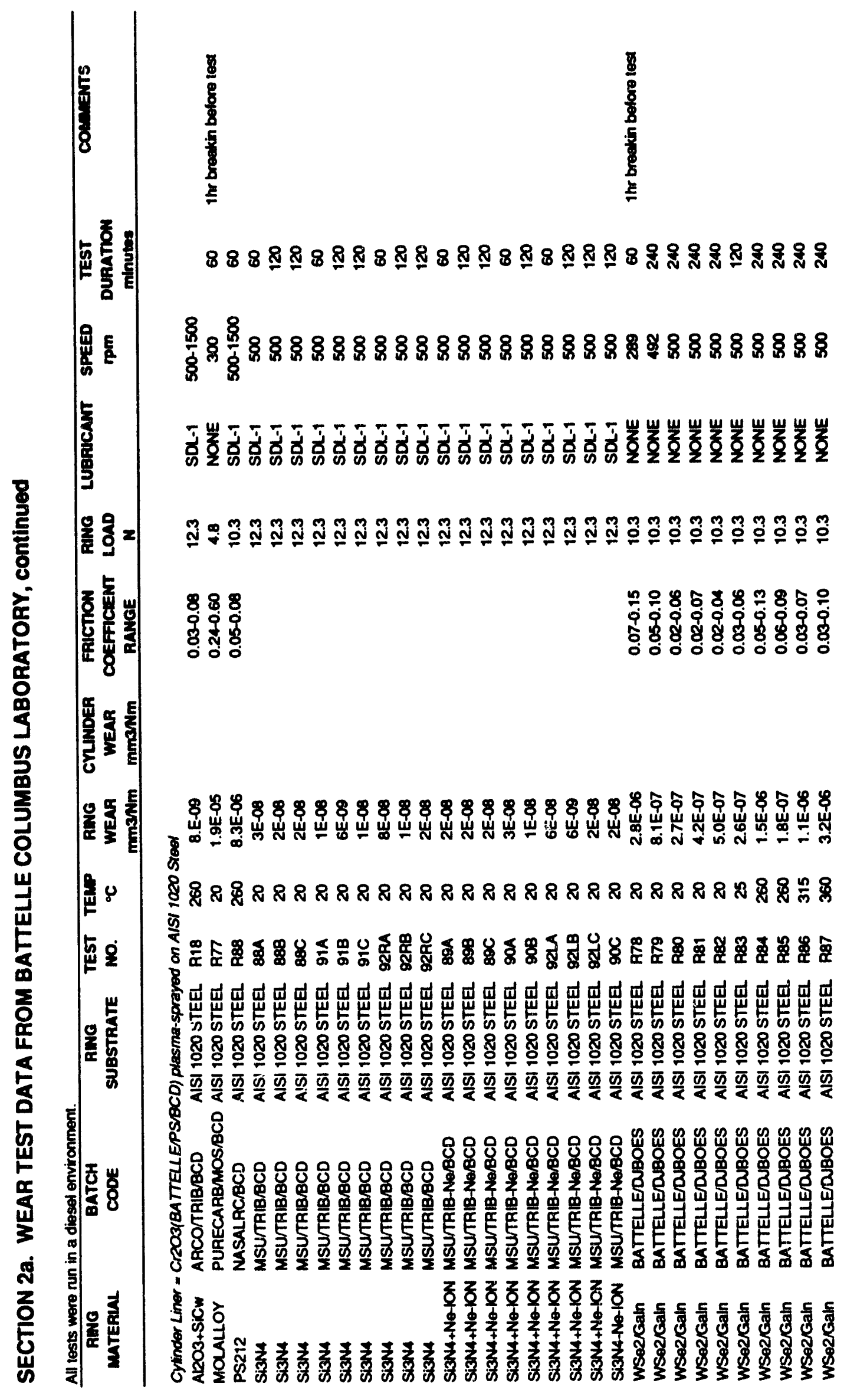




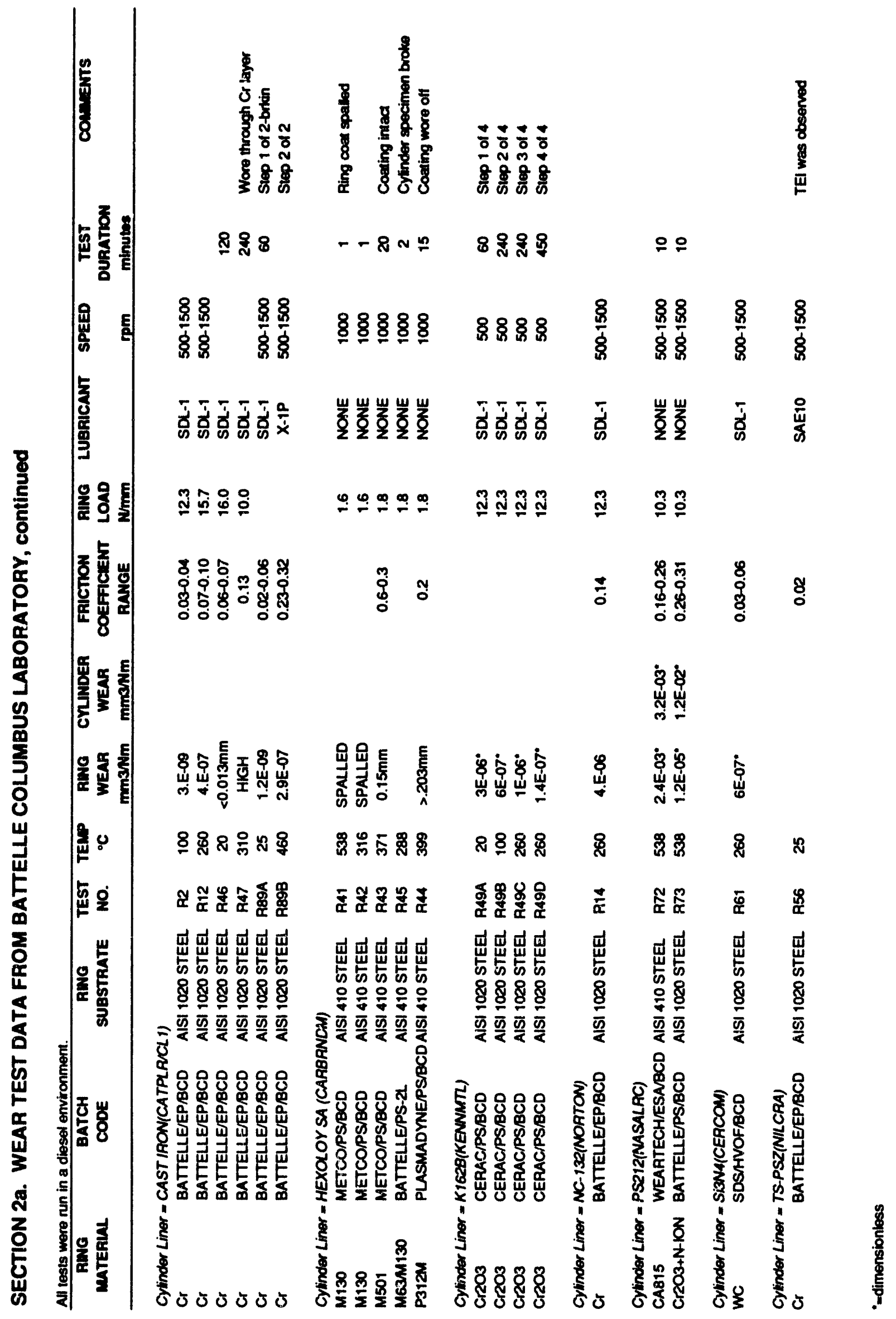




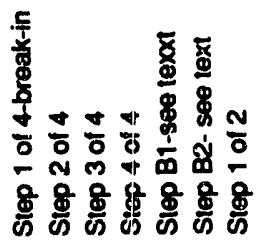

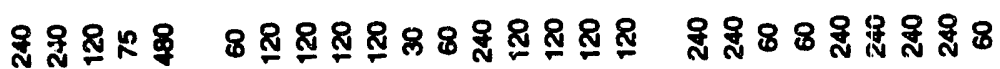

$\frac{8}{8}$

$\frac{8}{8}$

$8 \% 8 \%$

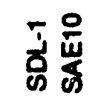

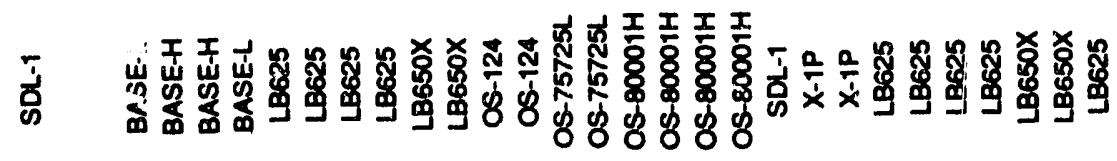

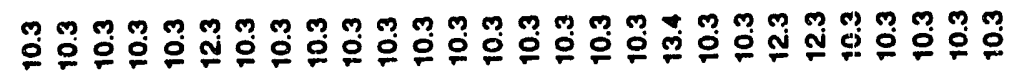

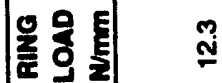



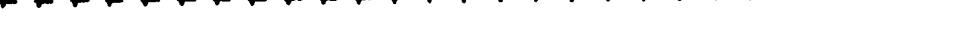

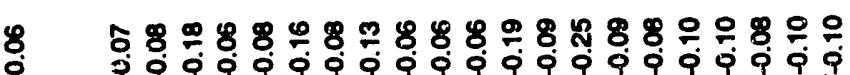

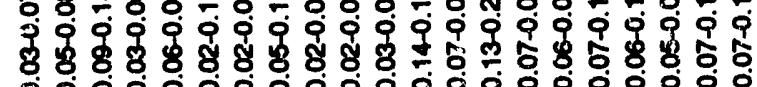

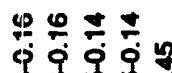

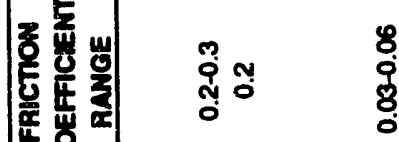

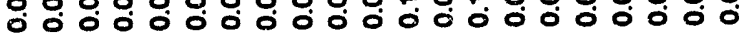

\$8.

敢

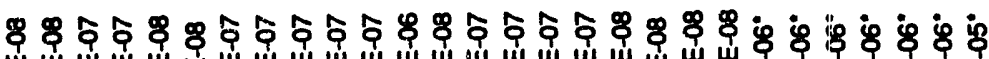

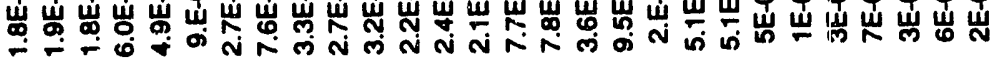

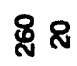

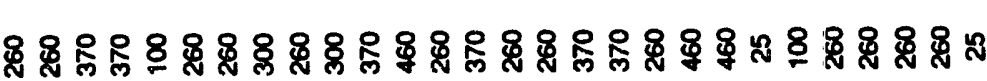
出

웅

के

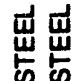

\&్d

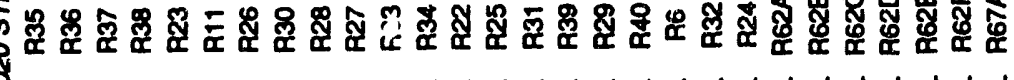

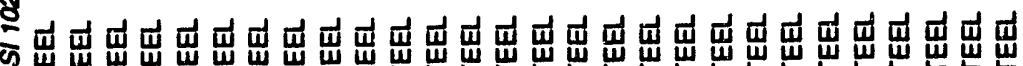

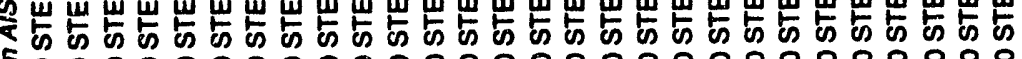

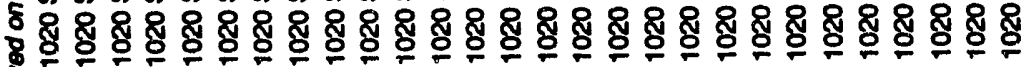

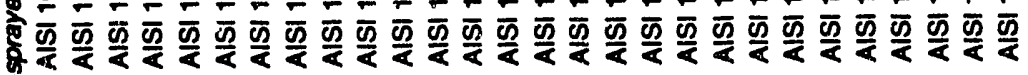
悹

邑邑

क्षे 잉

कू⿻

空

通

崖峲

잉

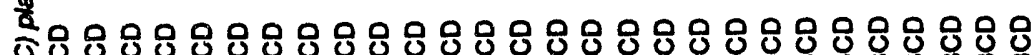

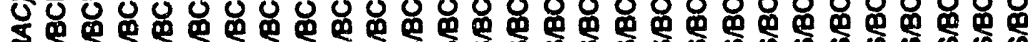

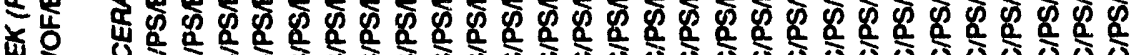




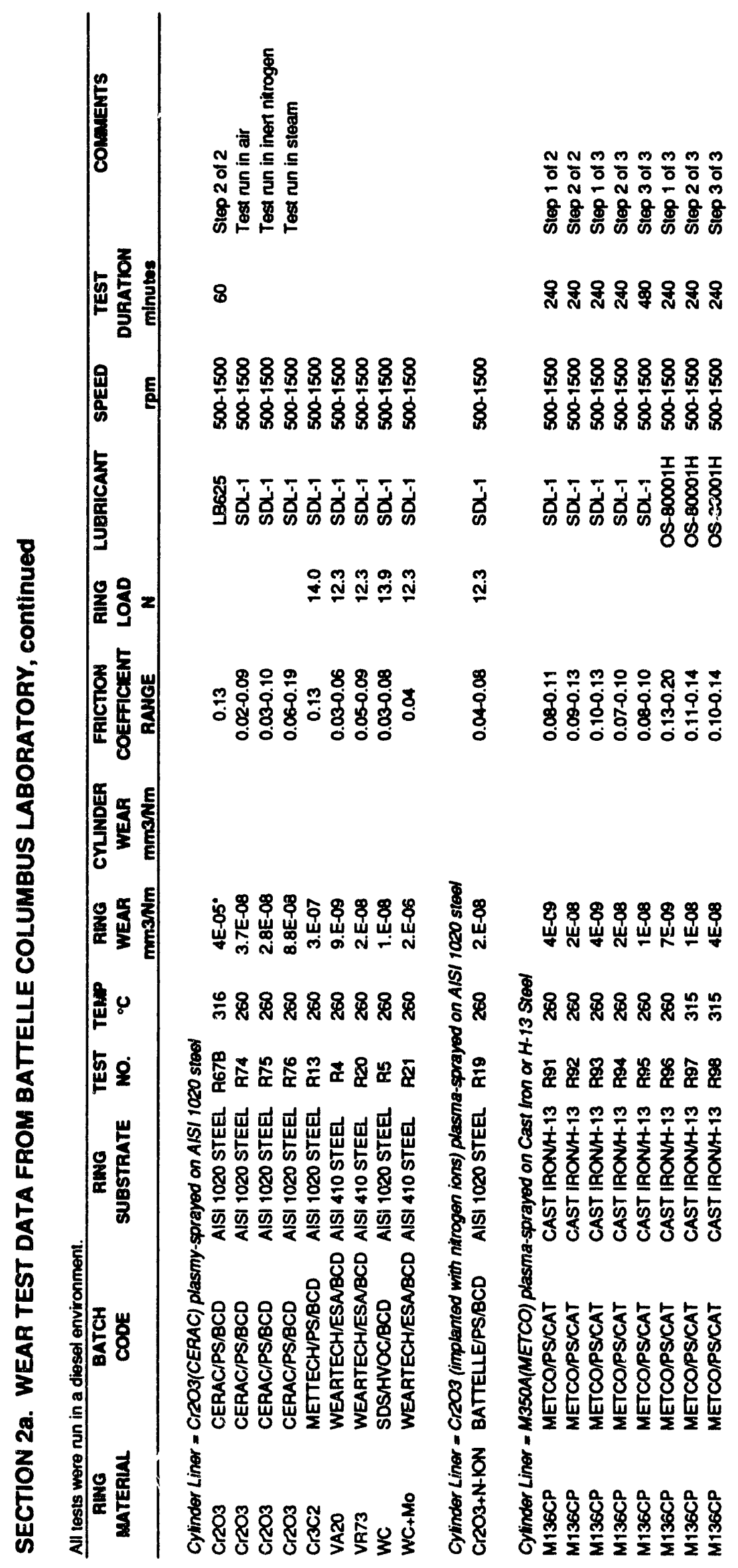




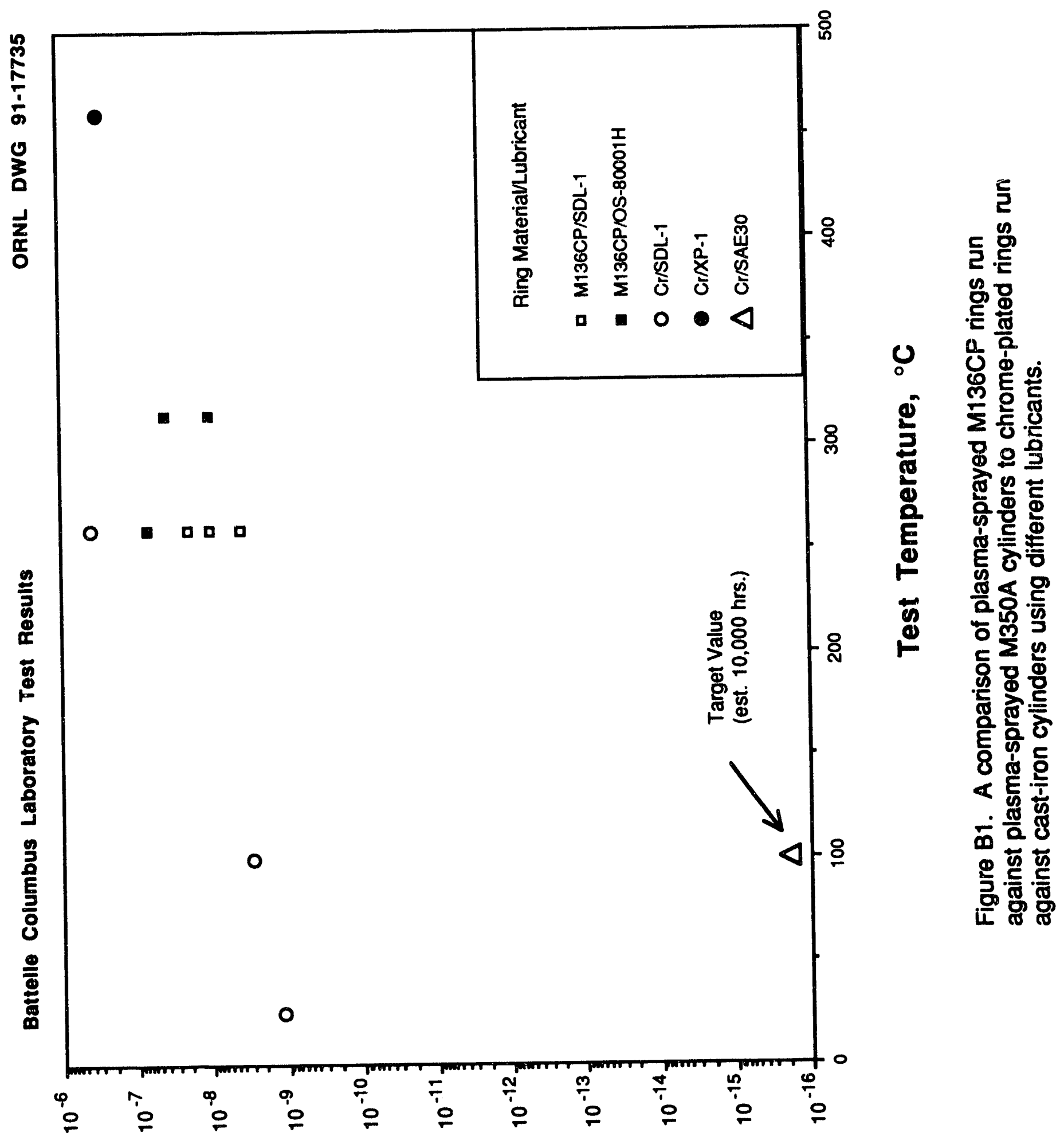

uN/Evwu 'dopoey seoM 


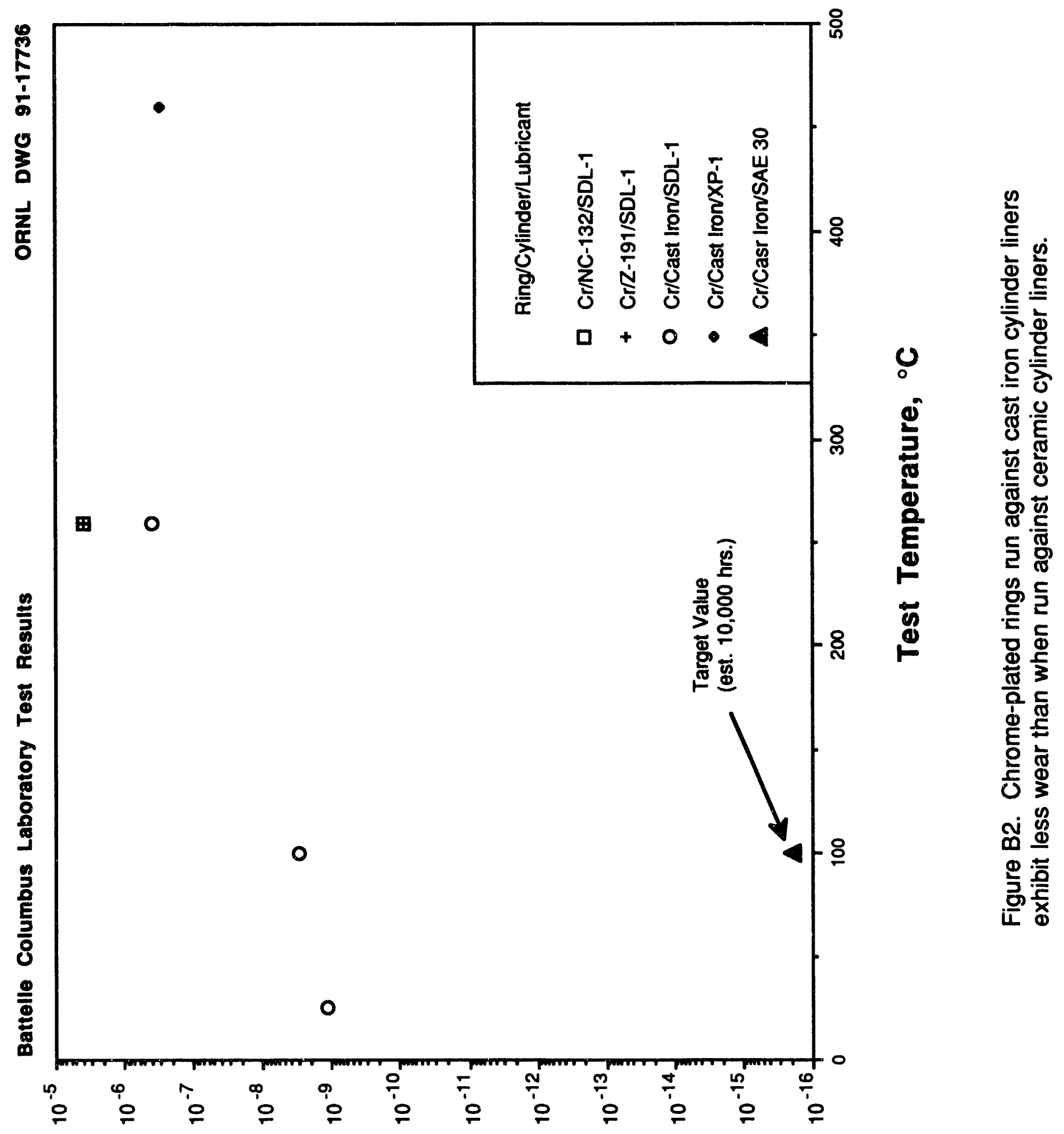

uN/Evmu 'dopoed JeәM 


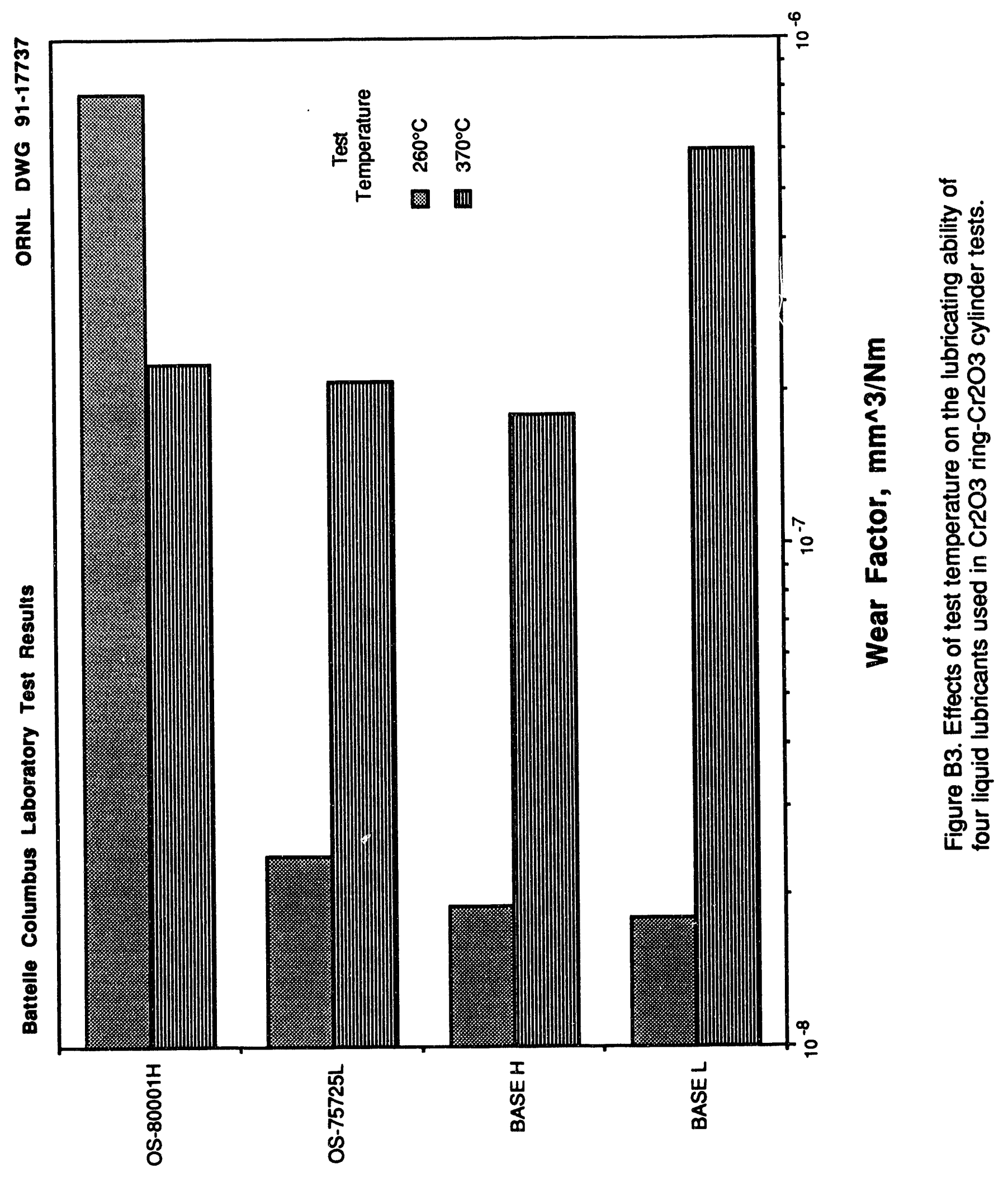




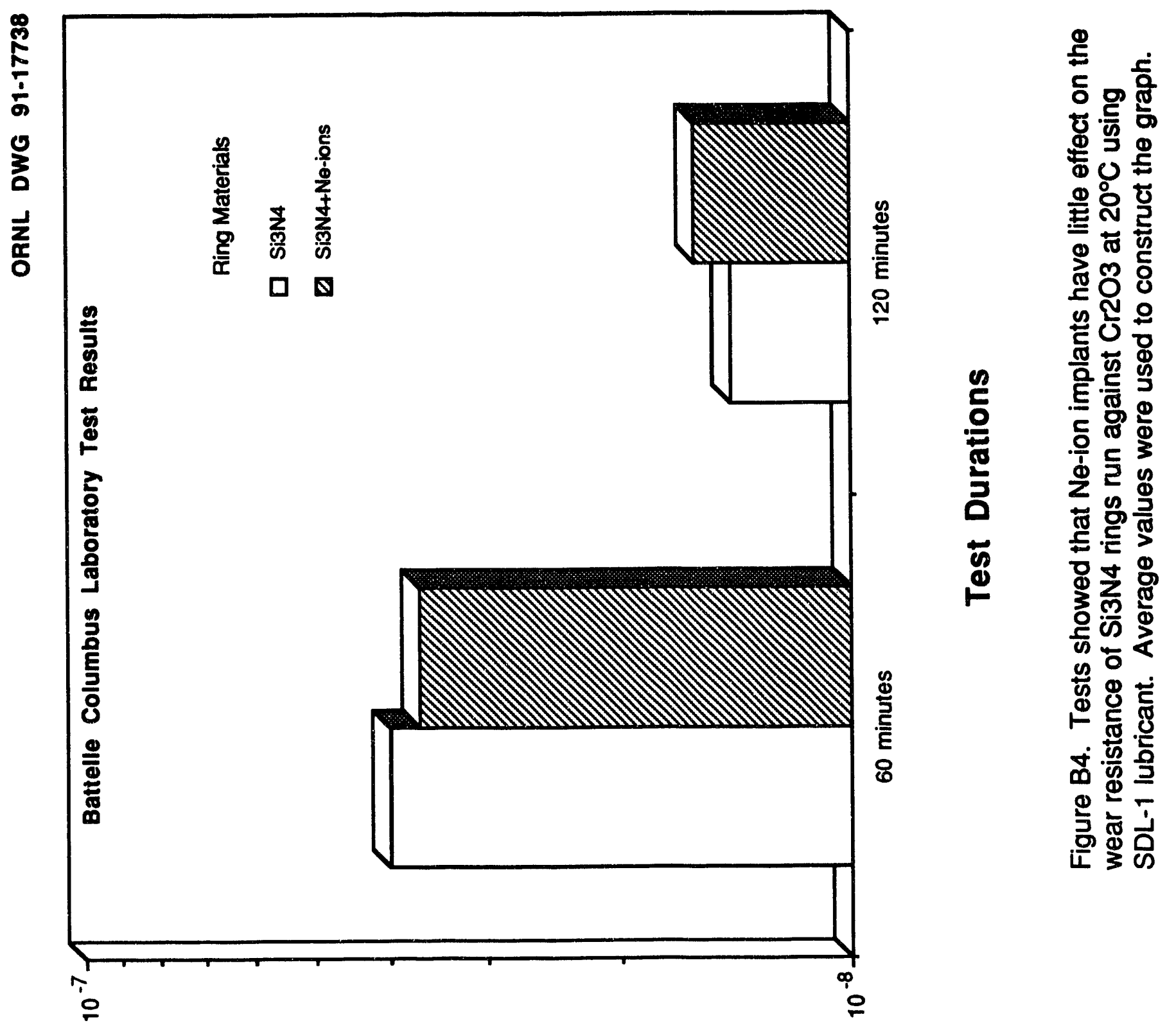

uN/Evwu 'деәм 


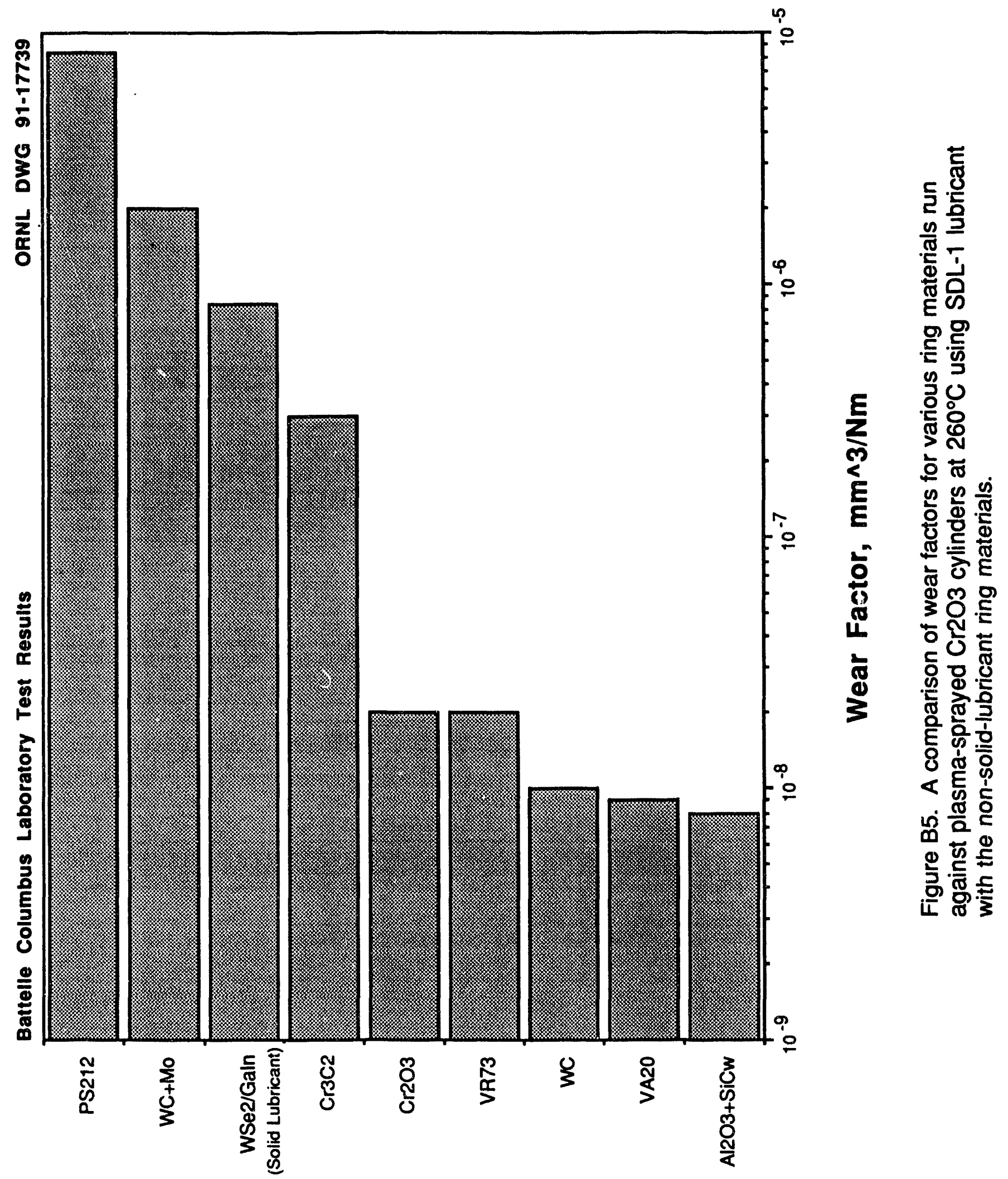




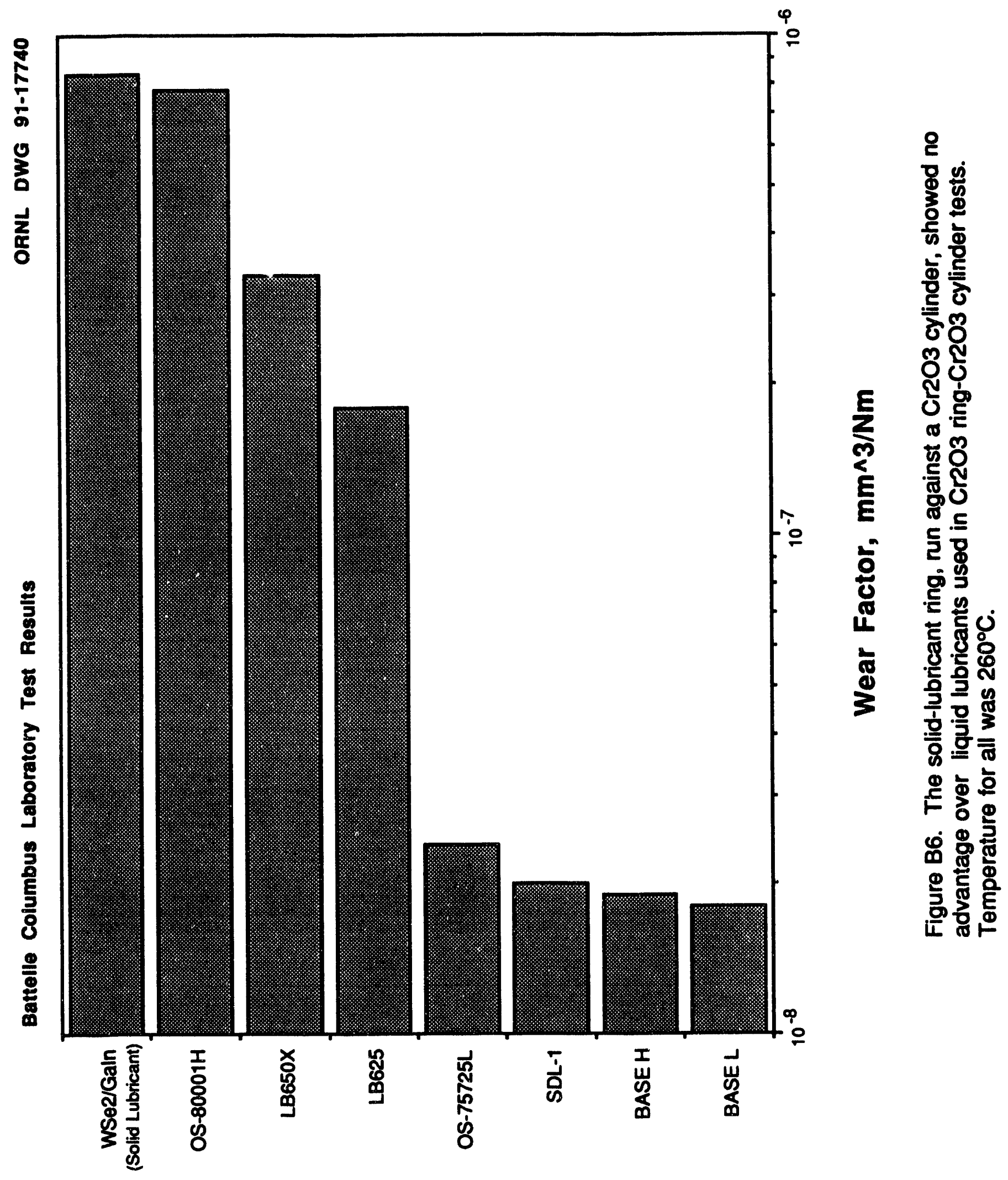




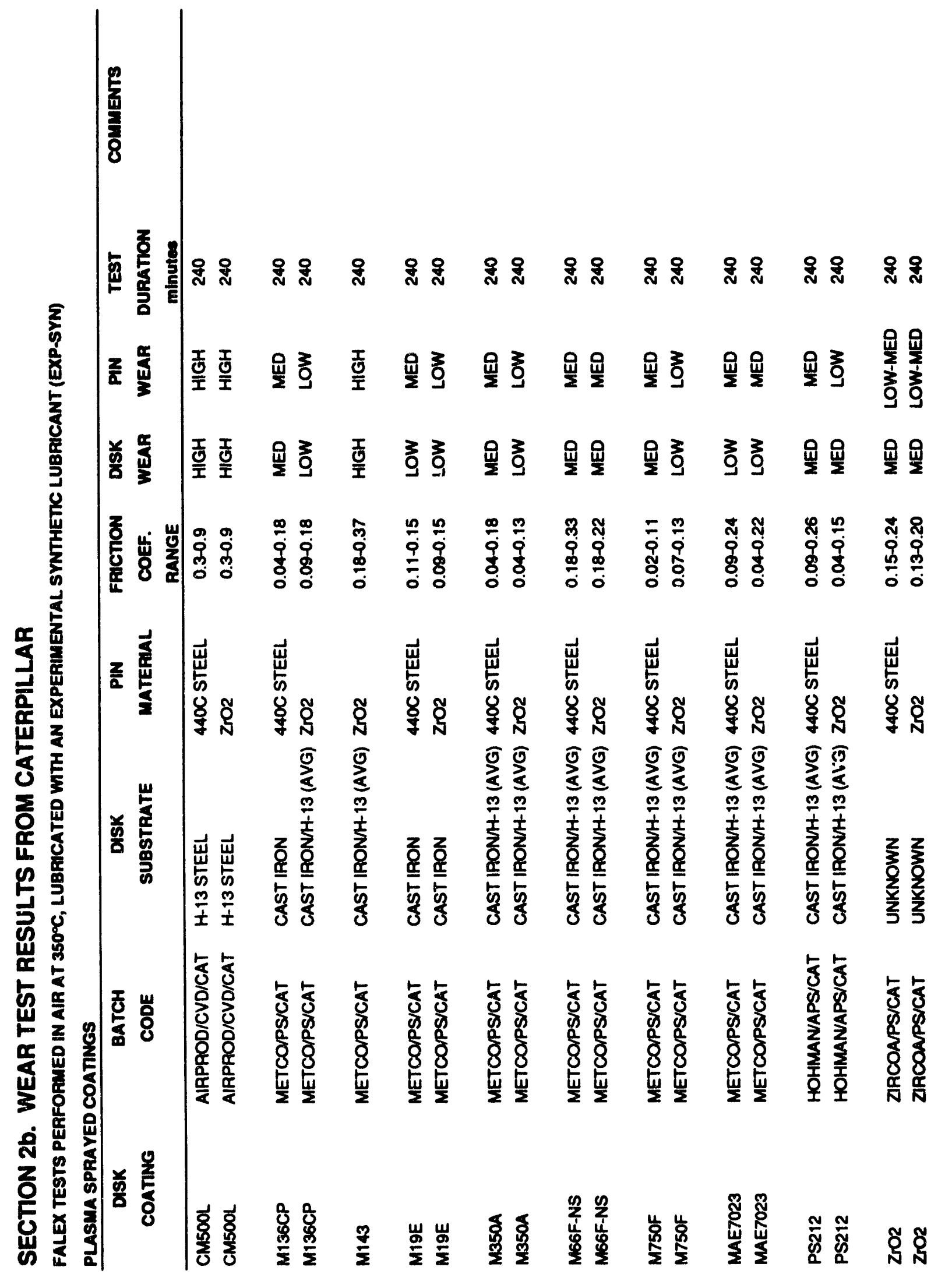




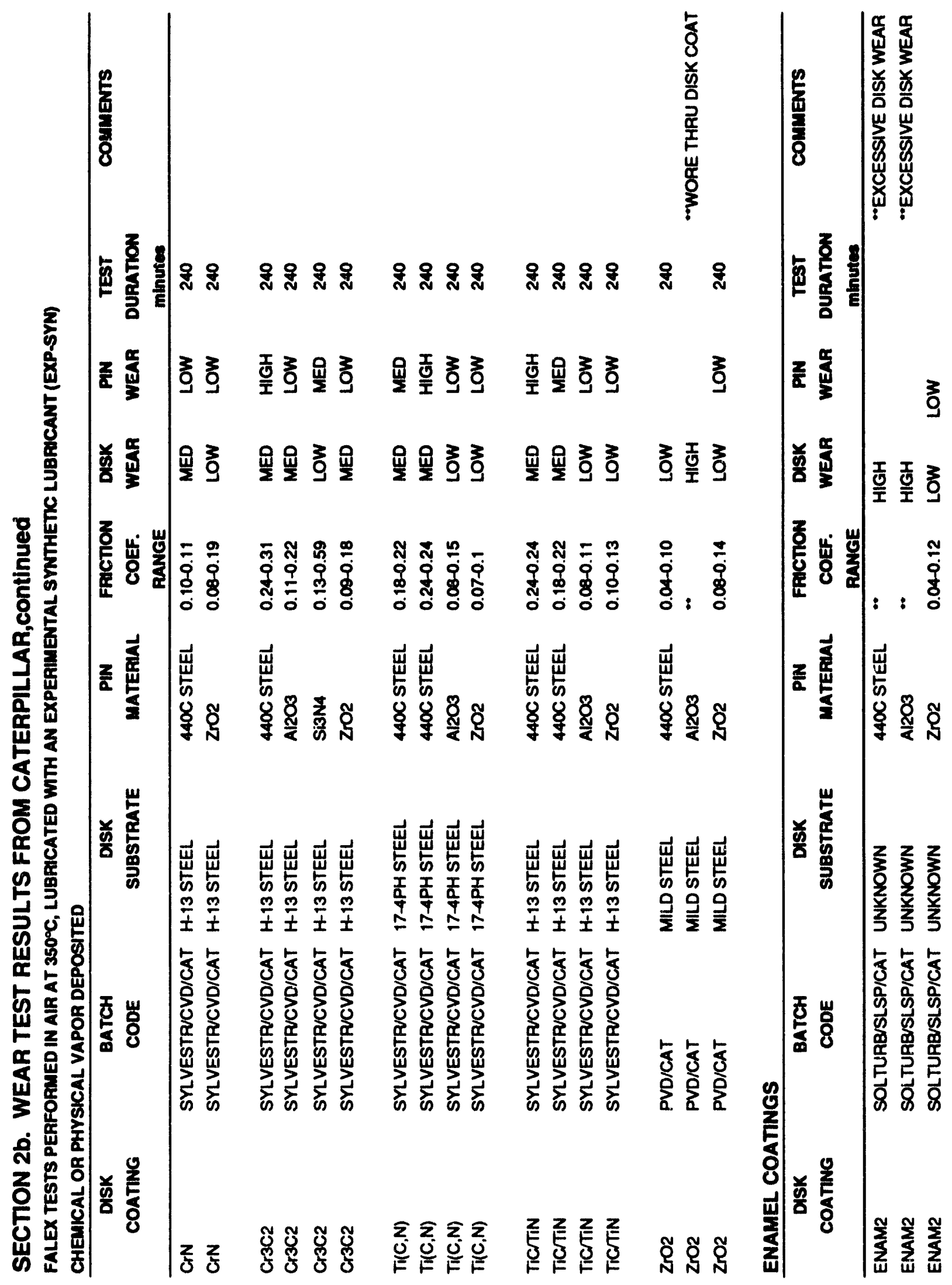




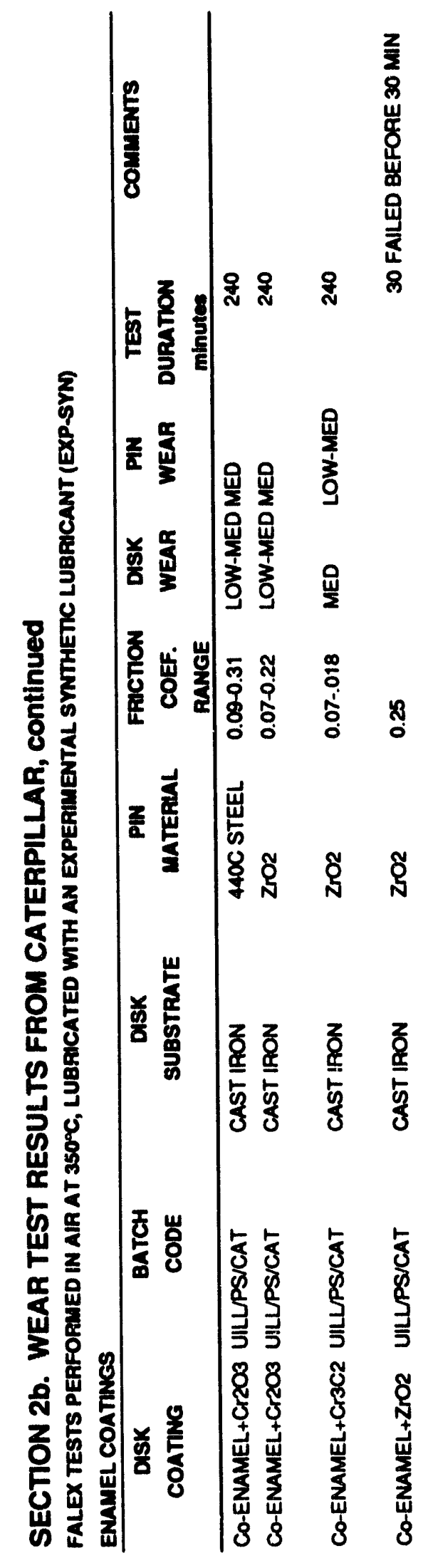




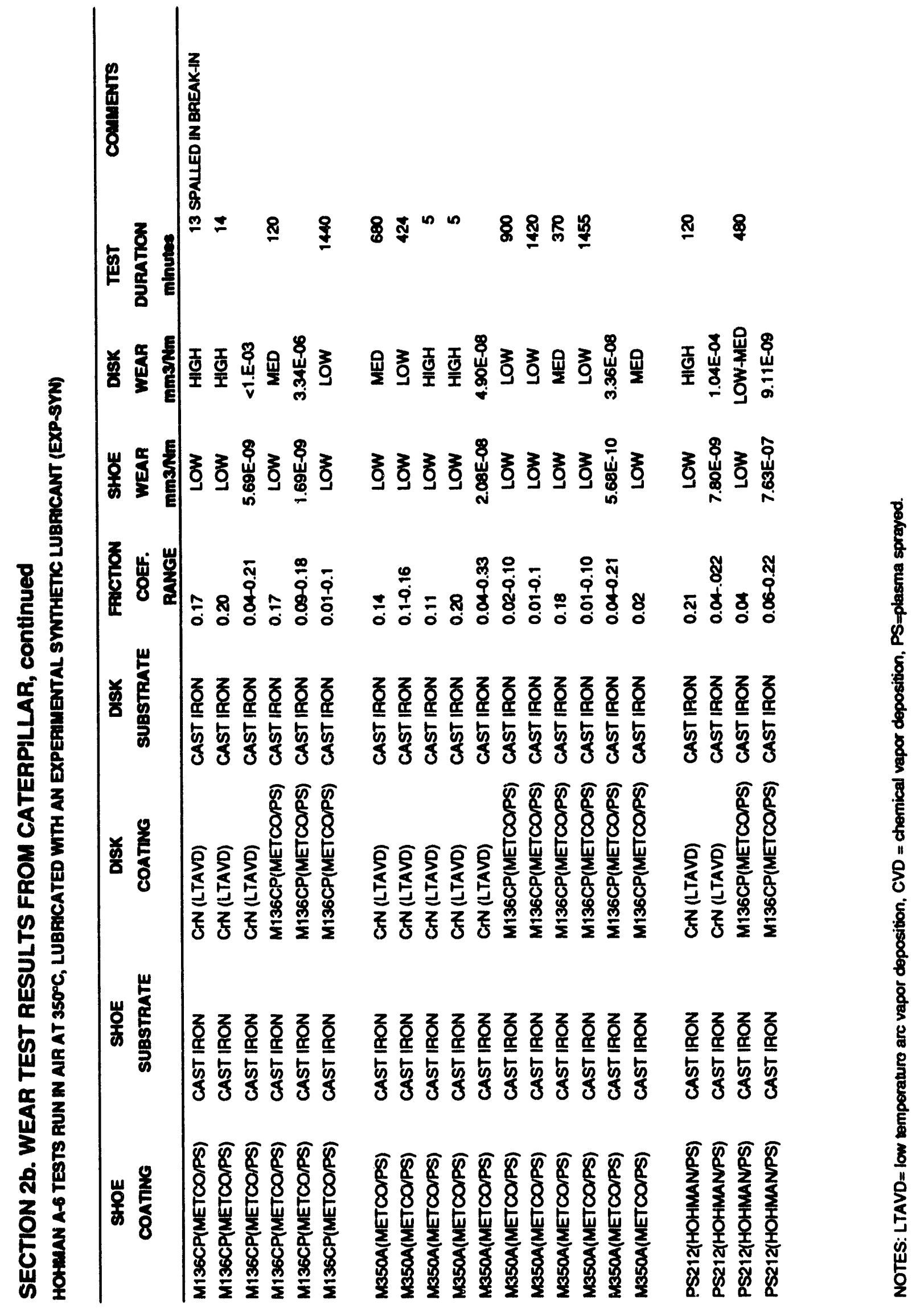




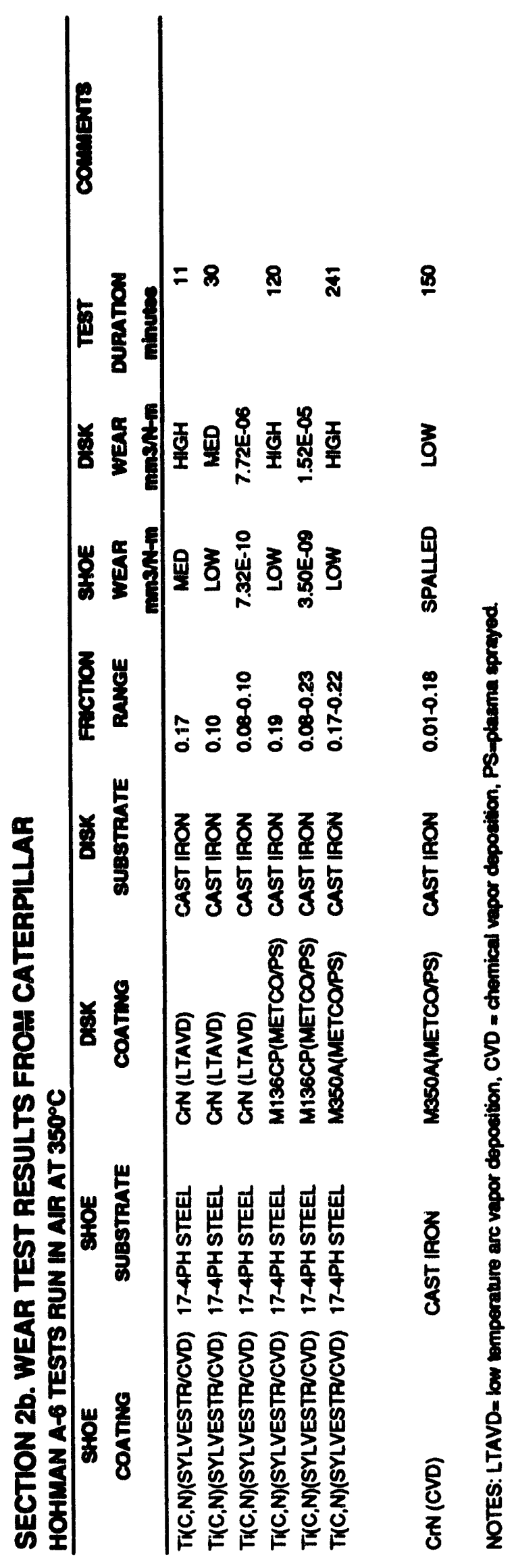




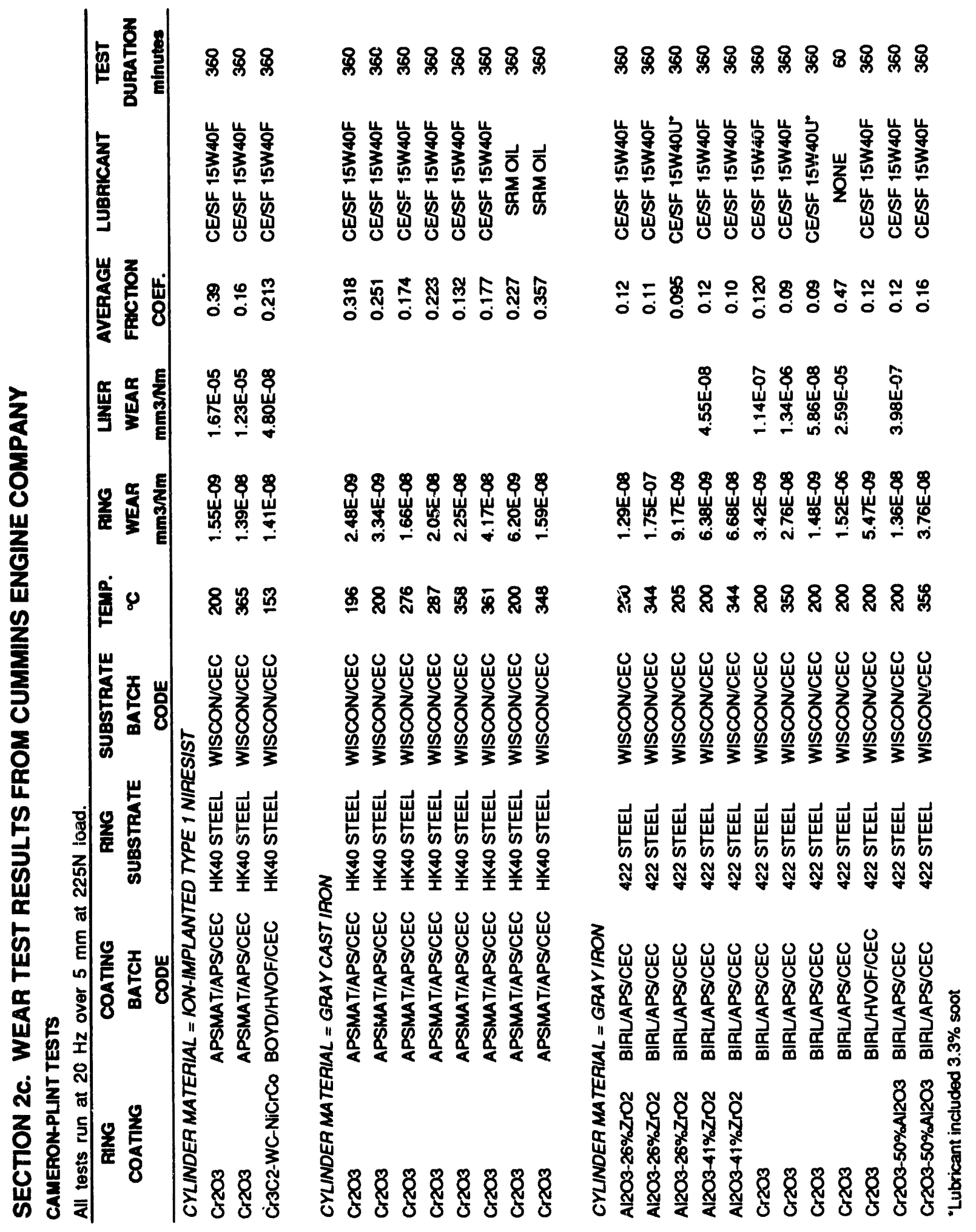




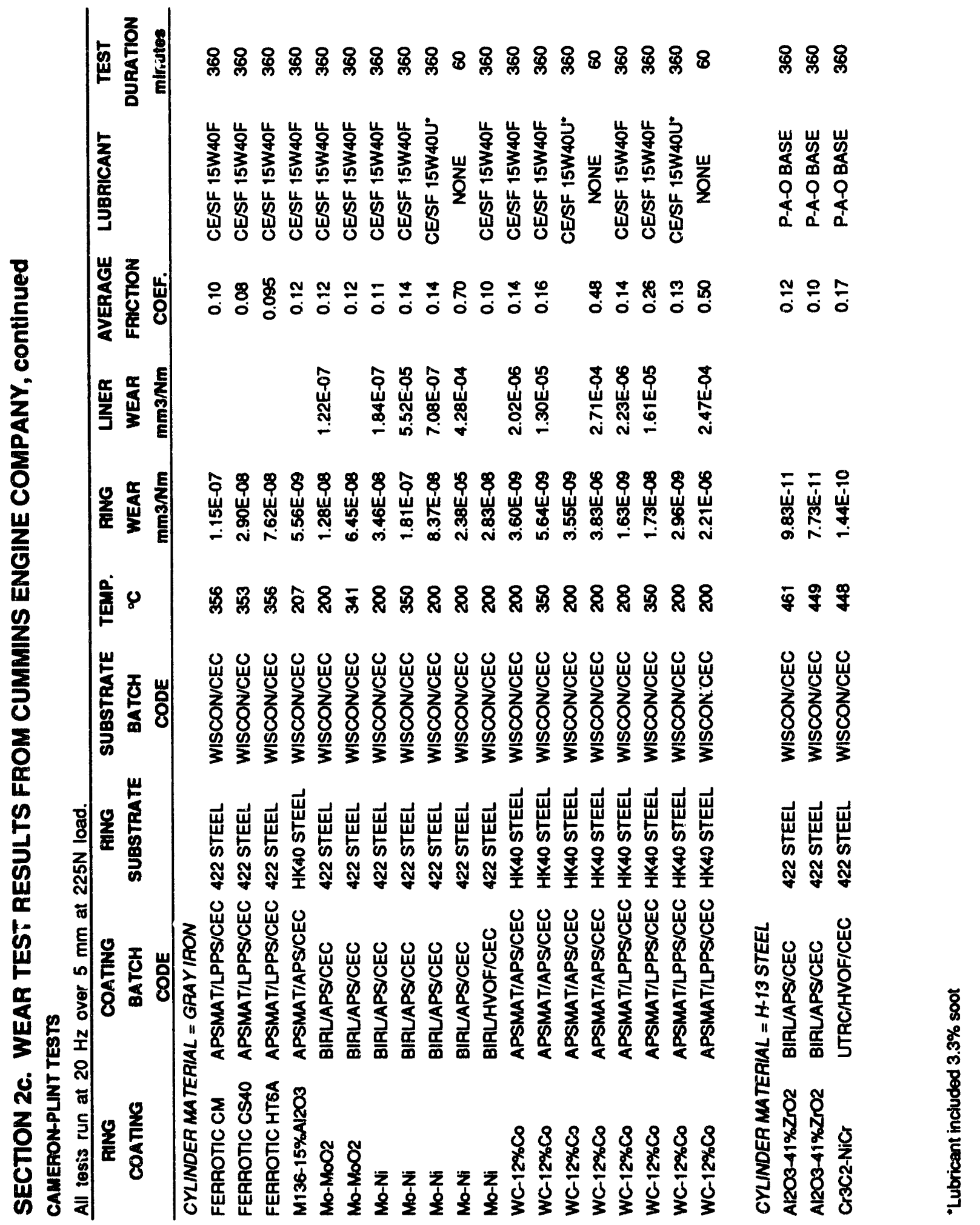




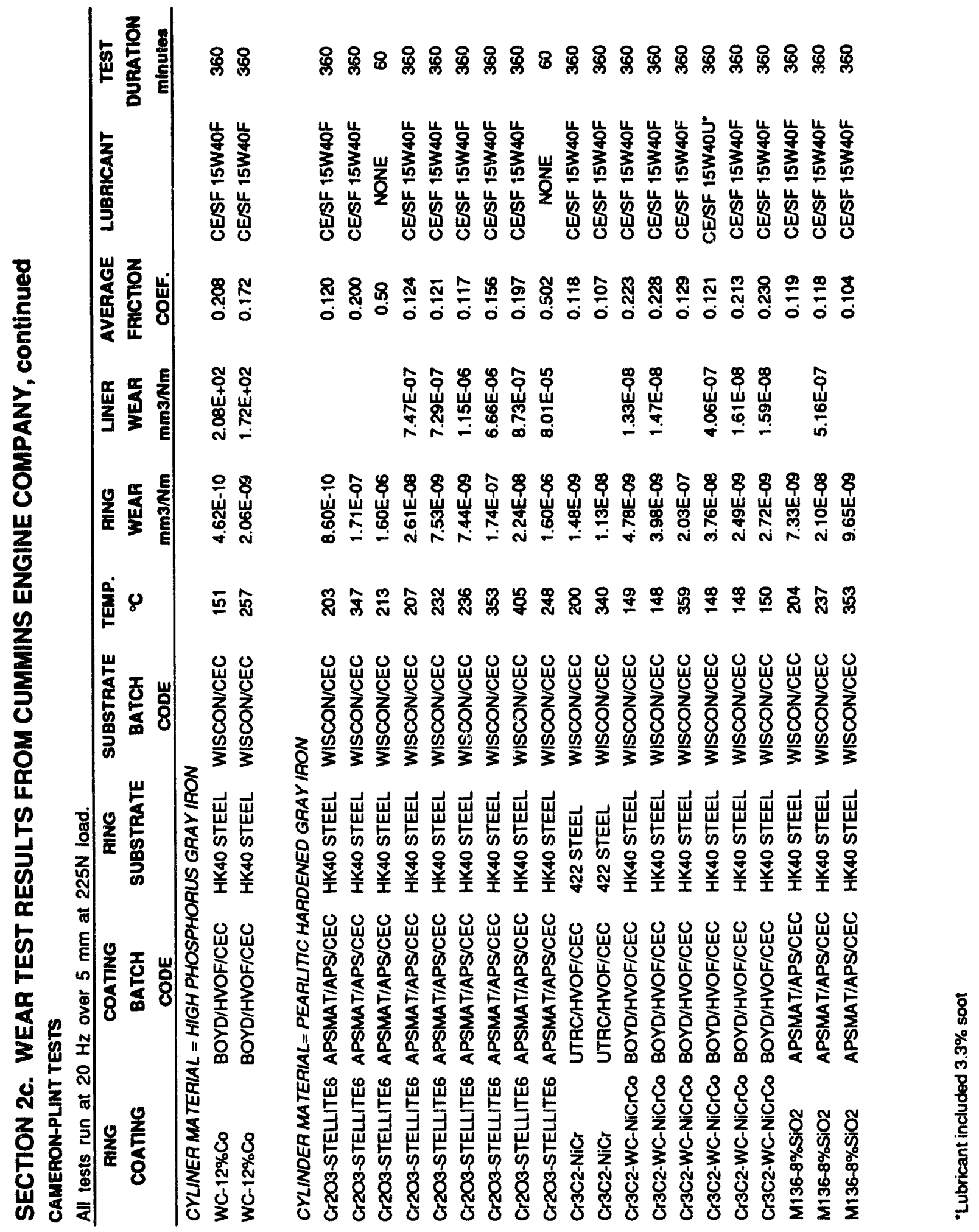




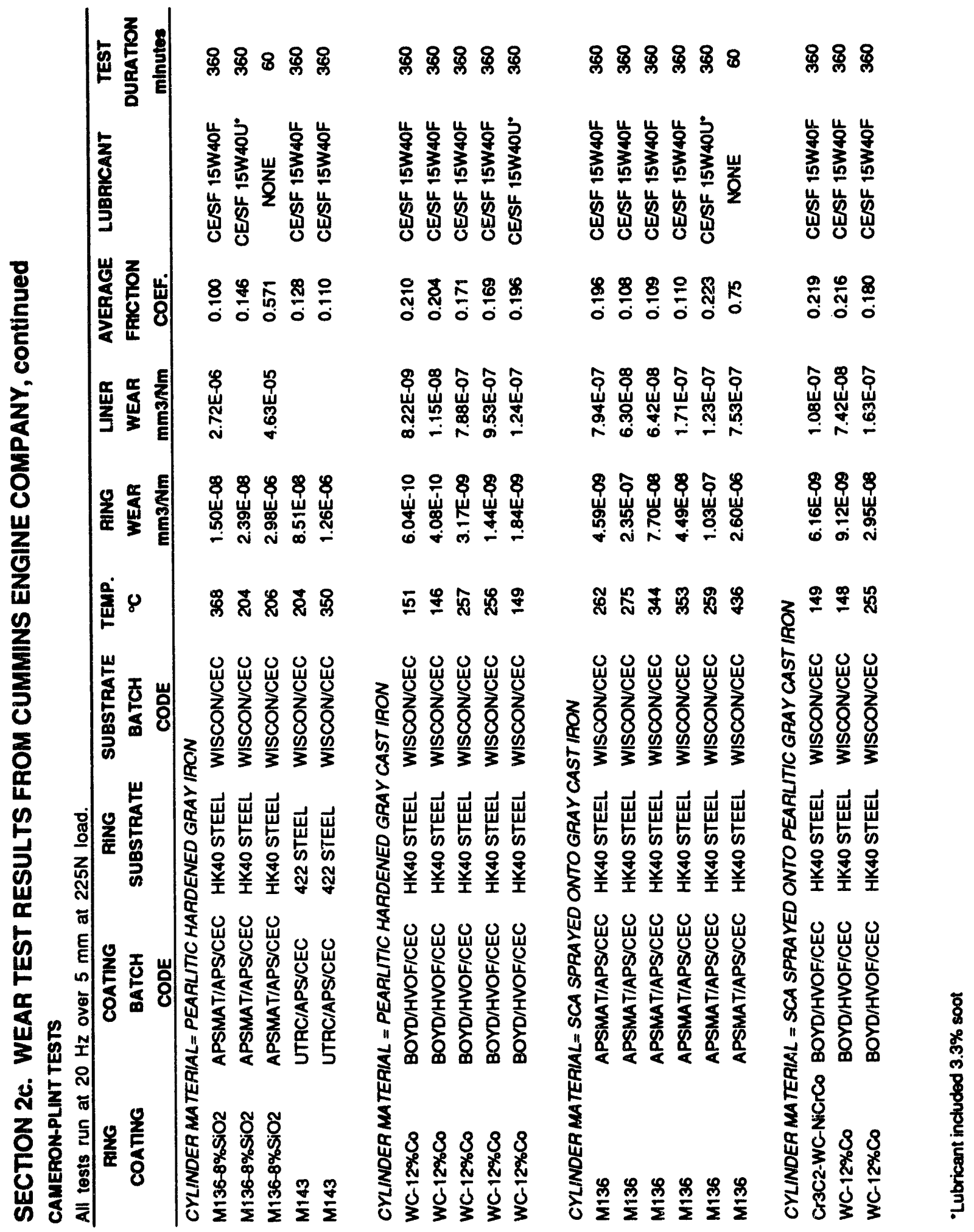




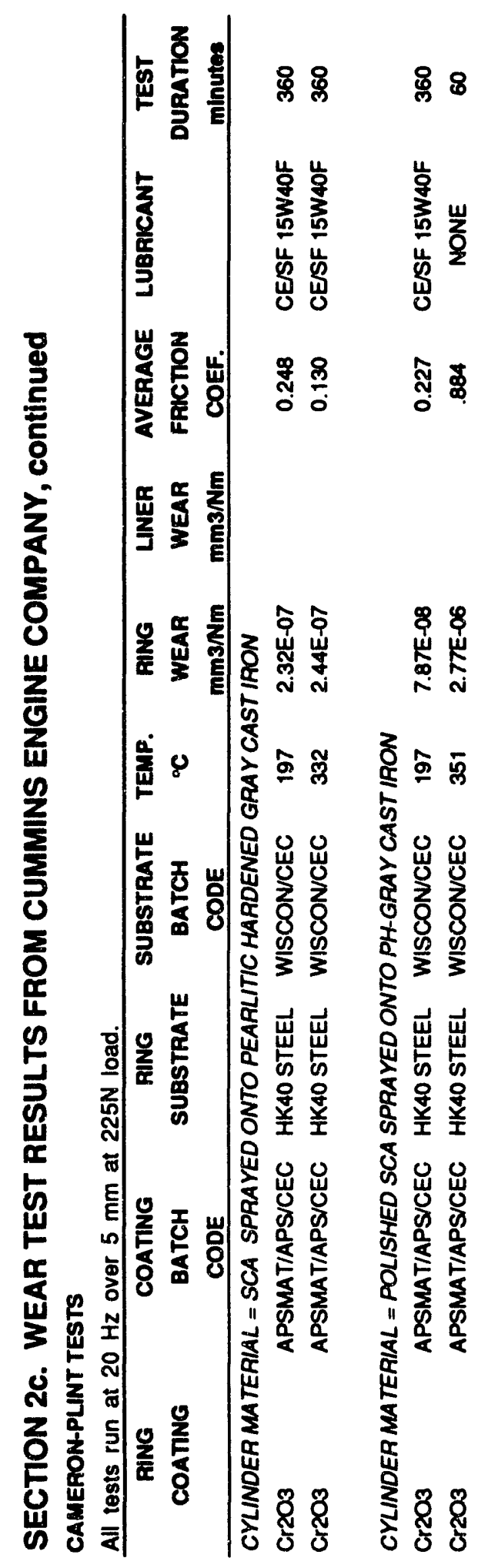

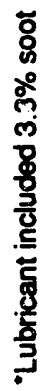




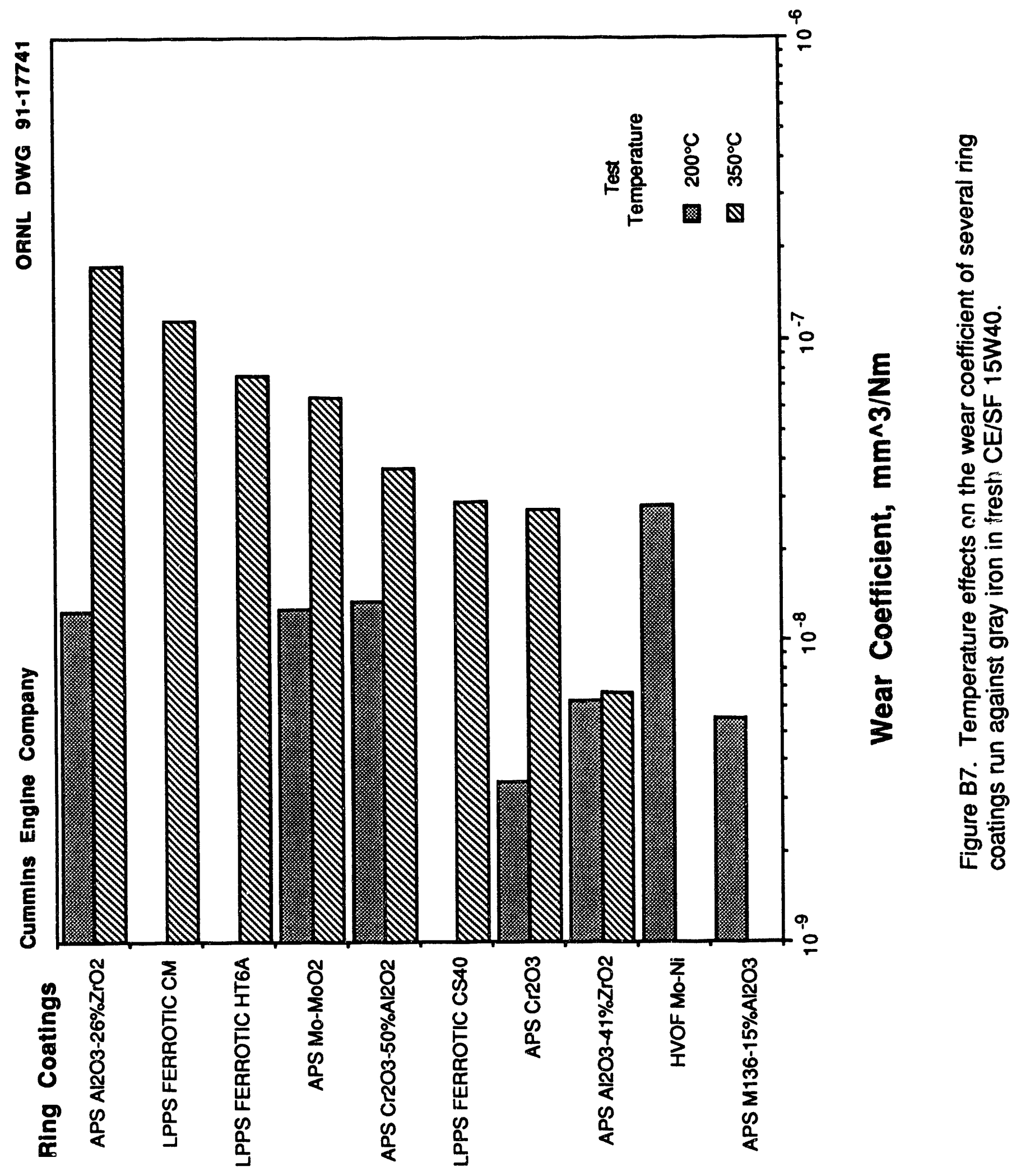




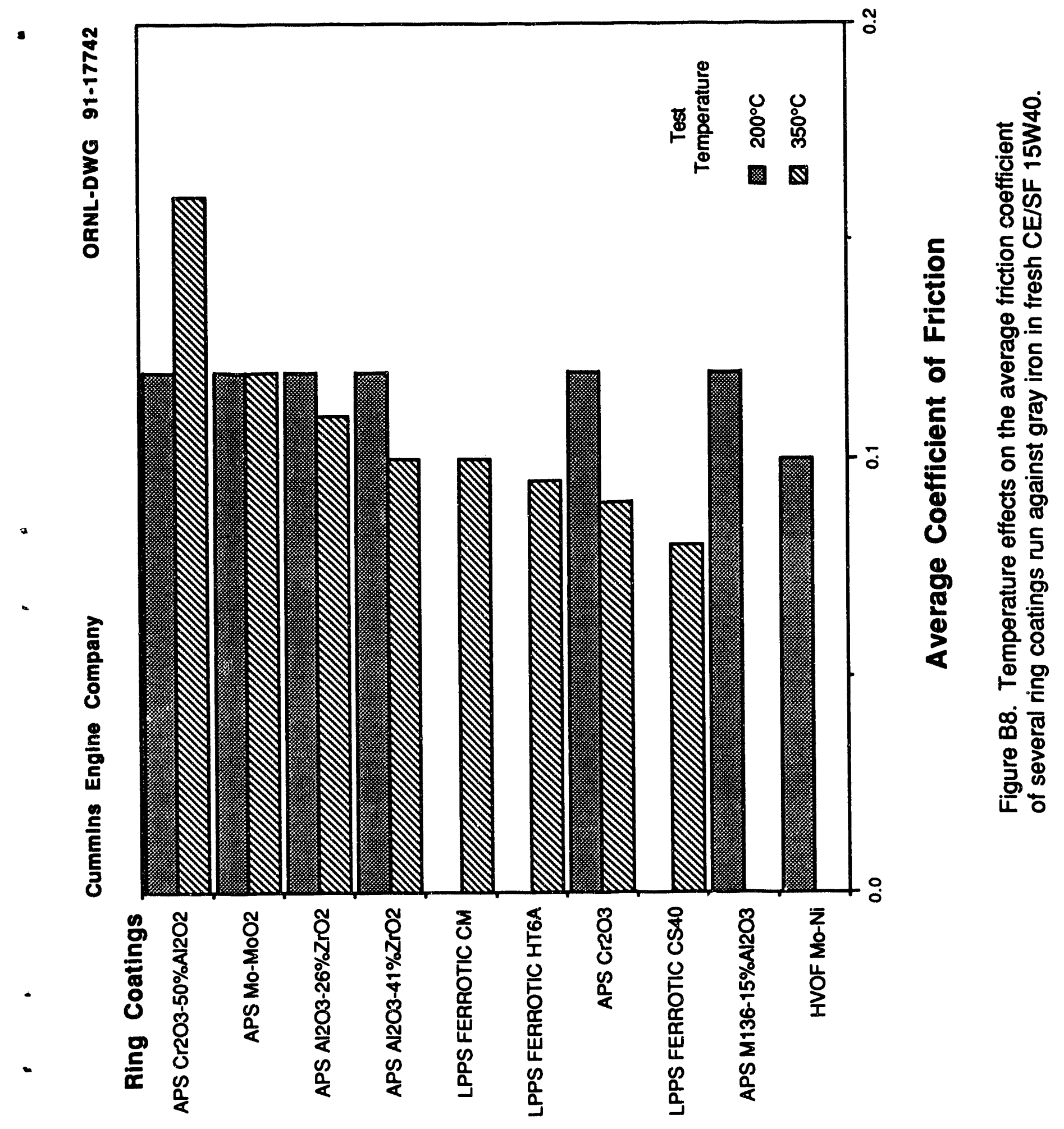




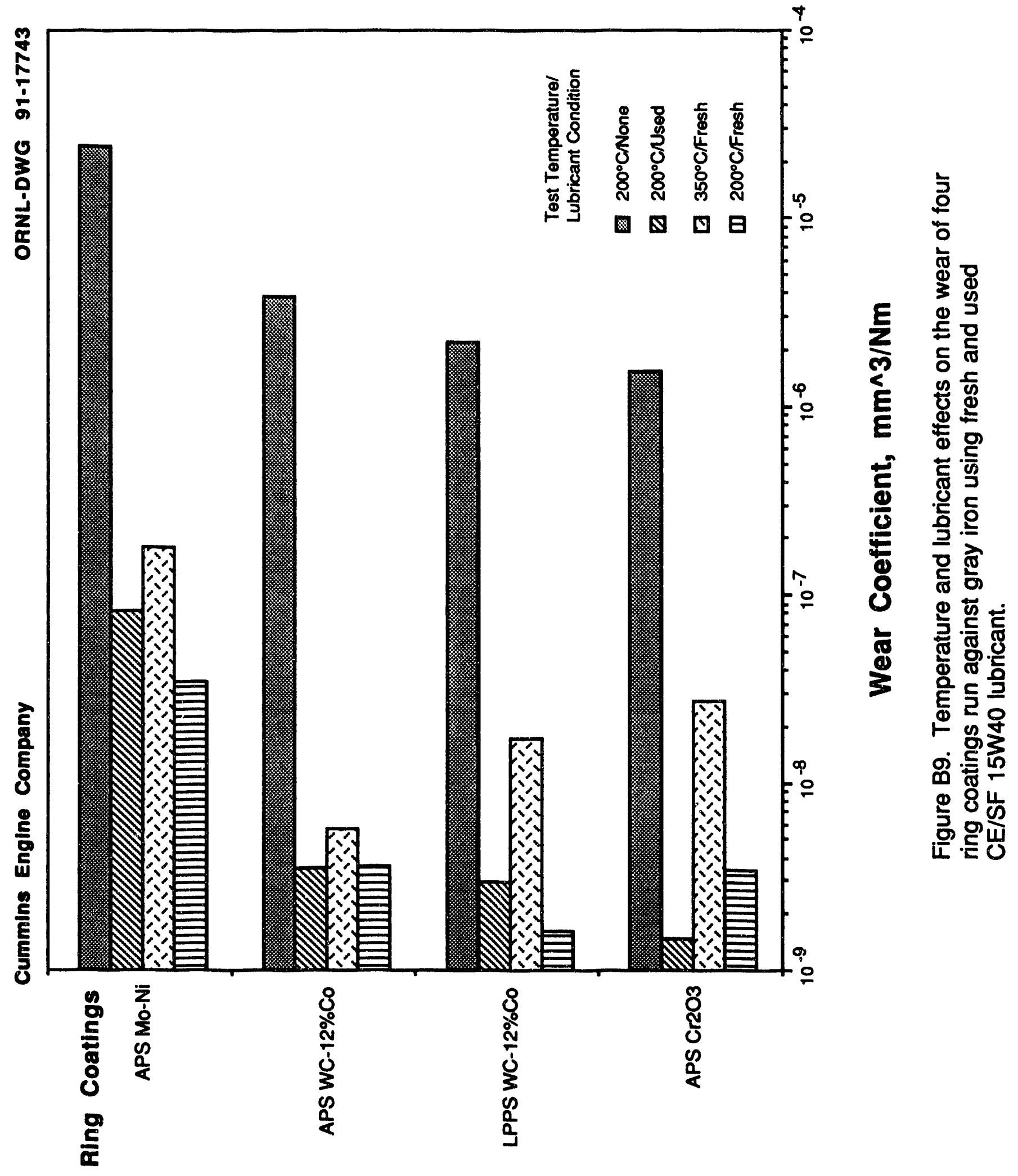




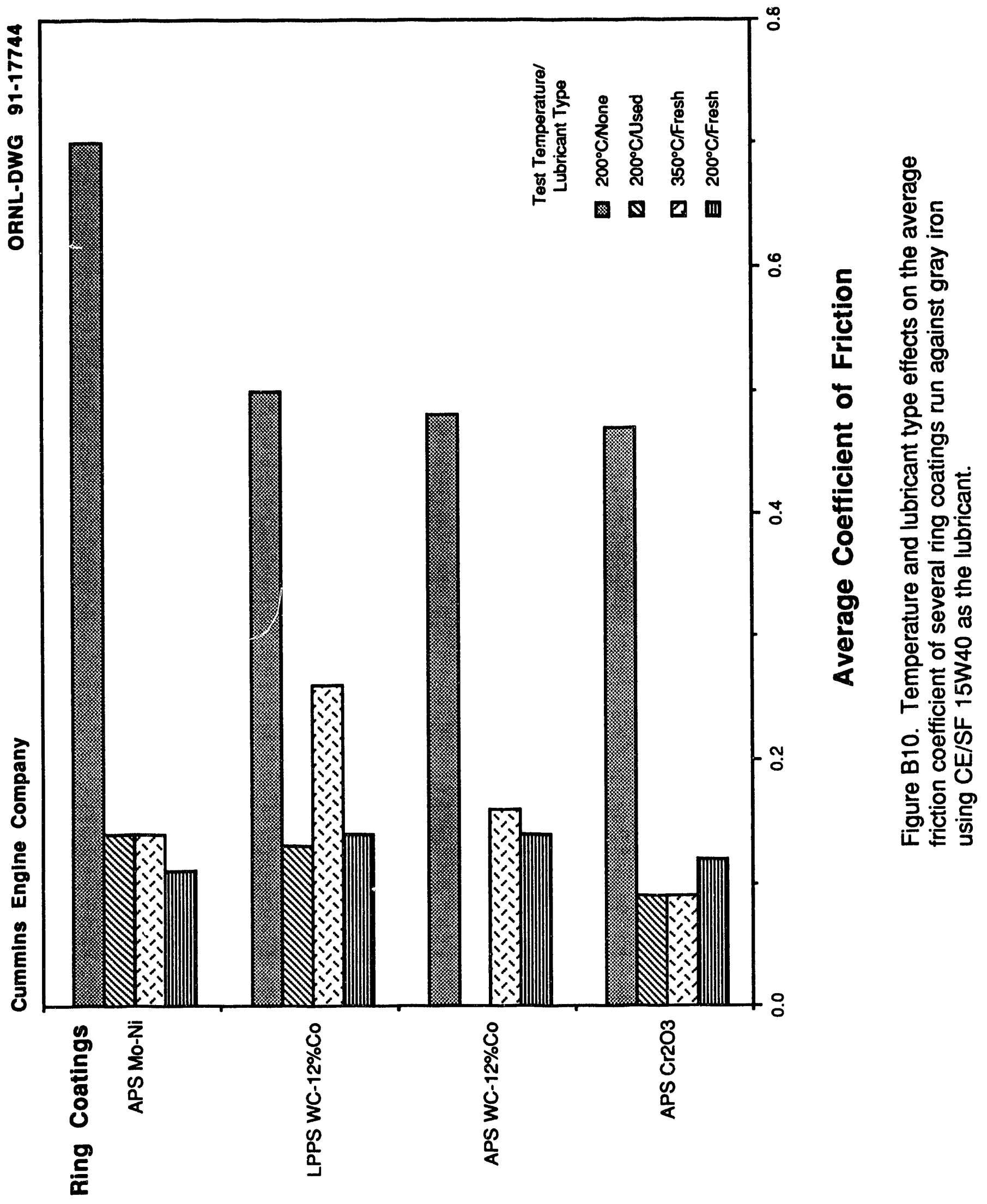




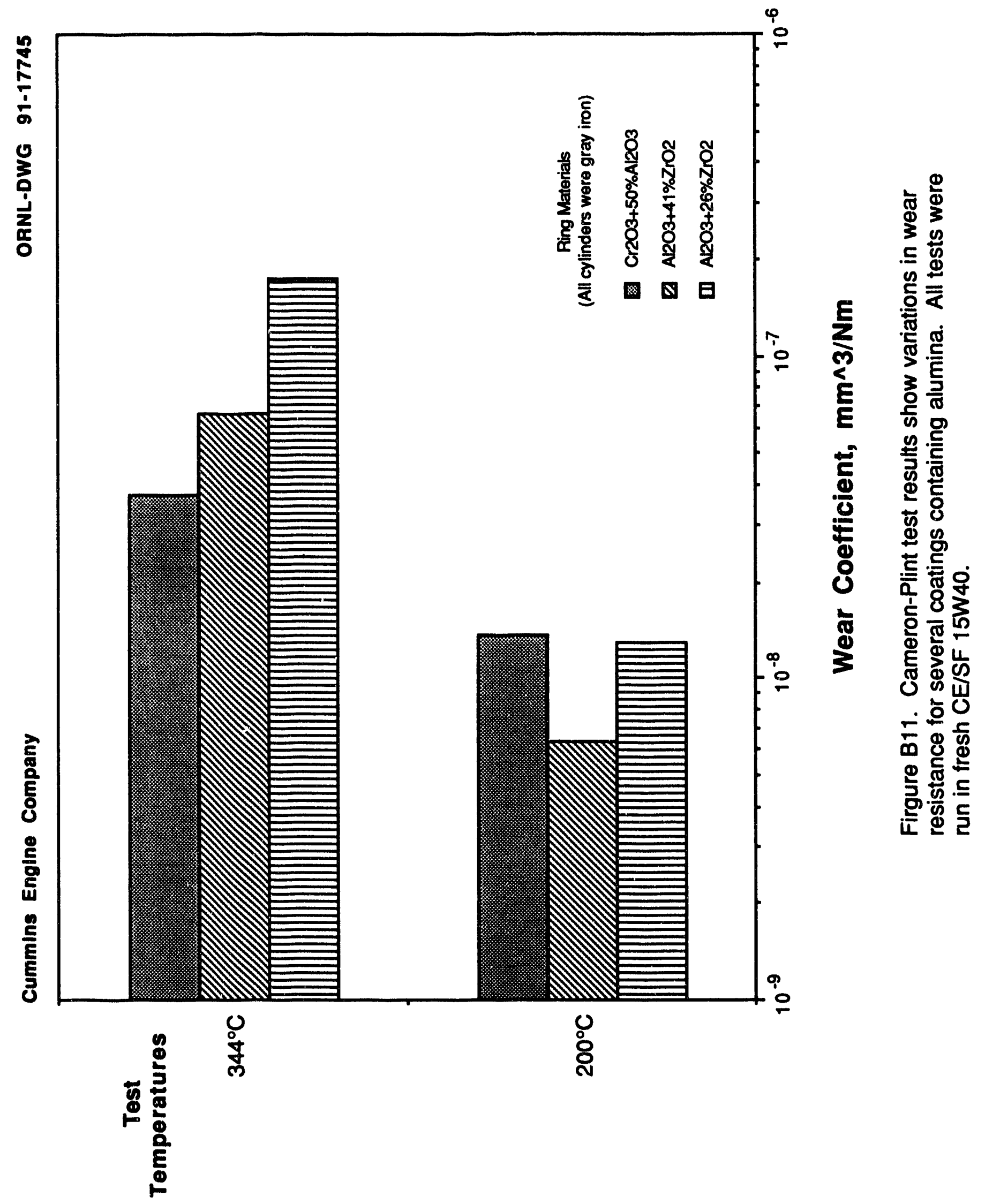




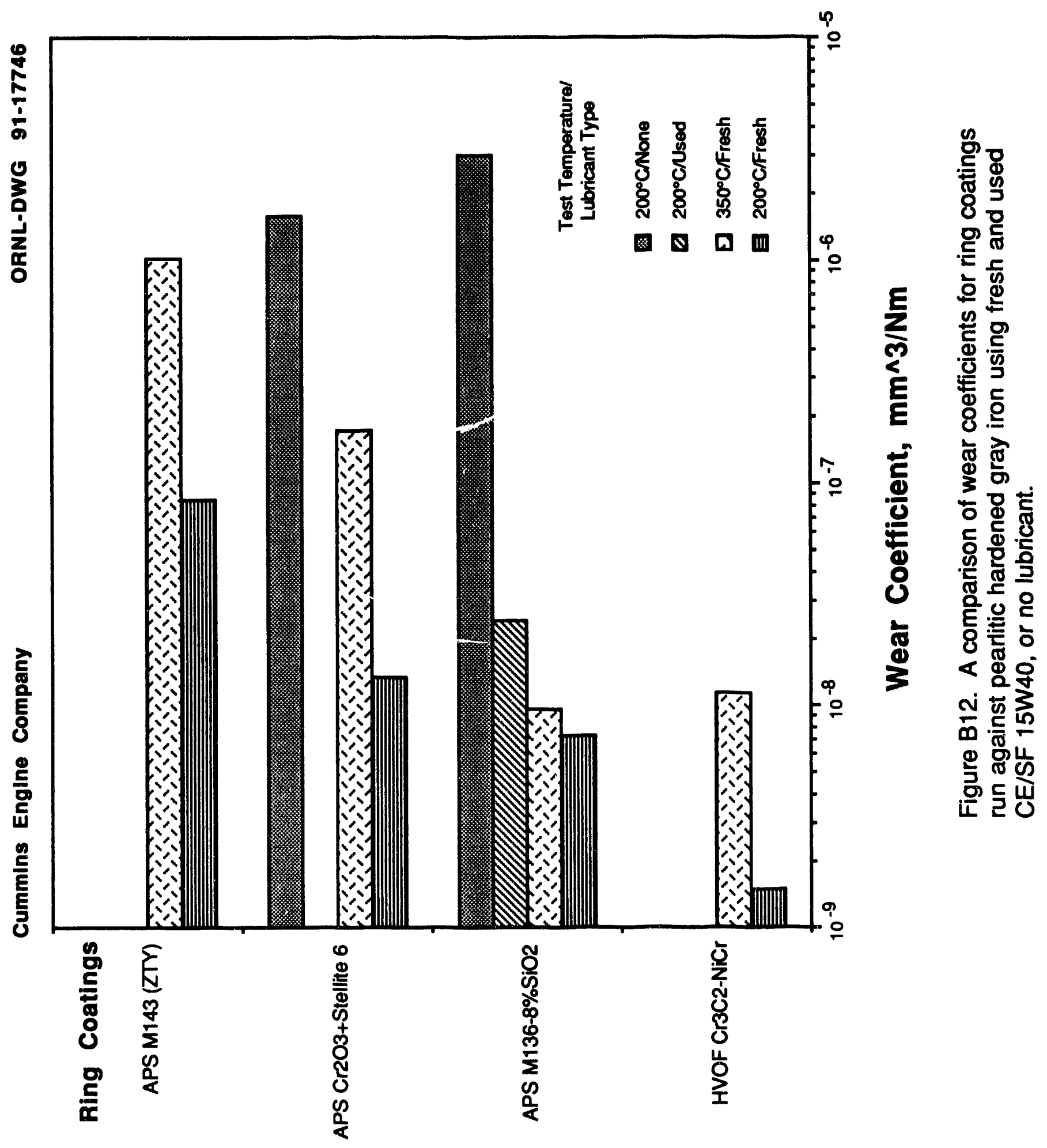




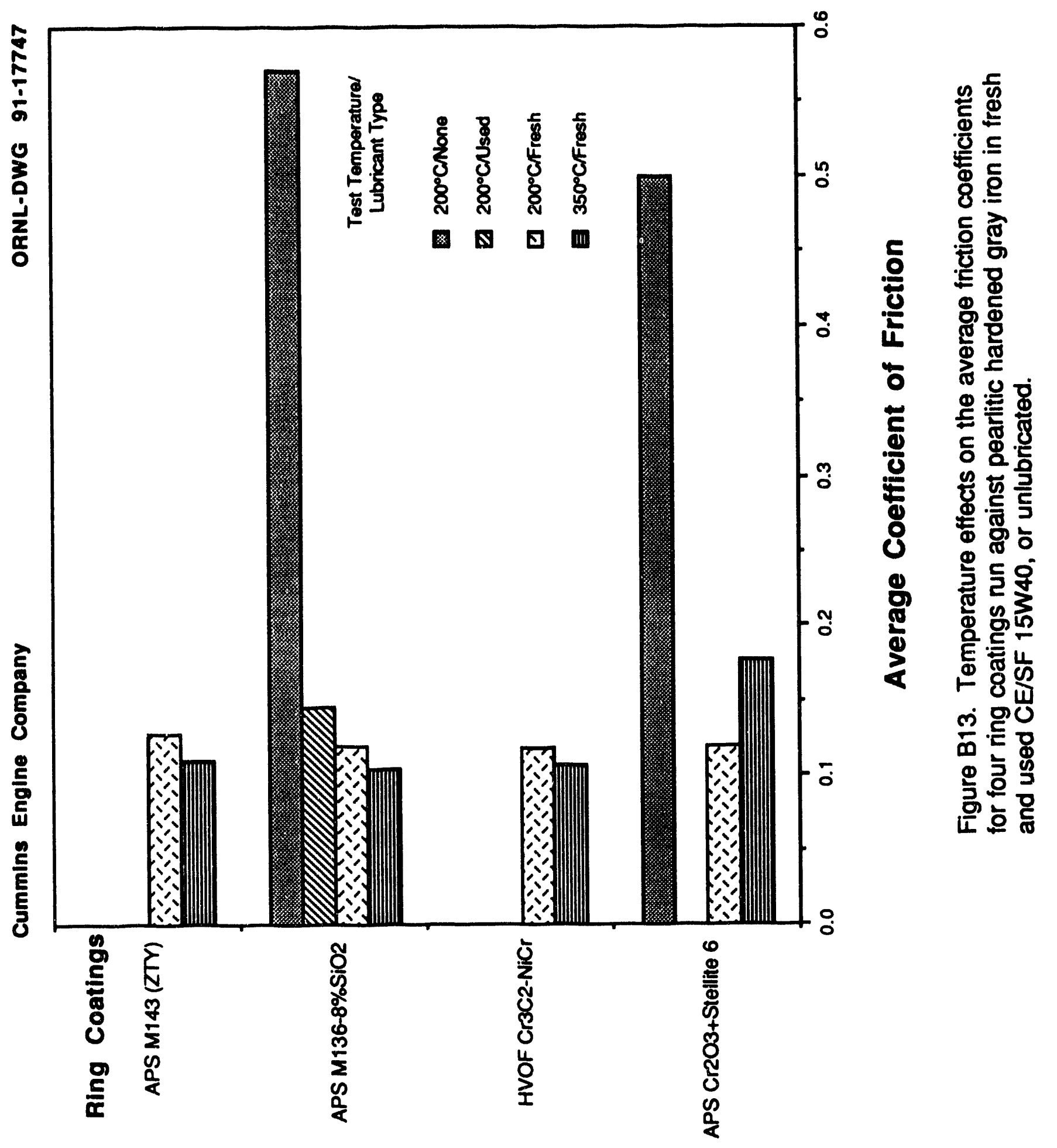




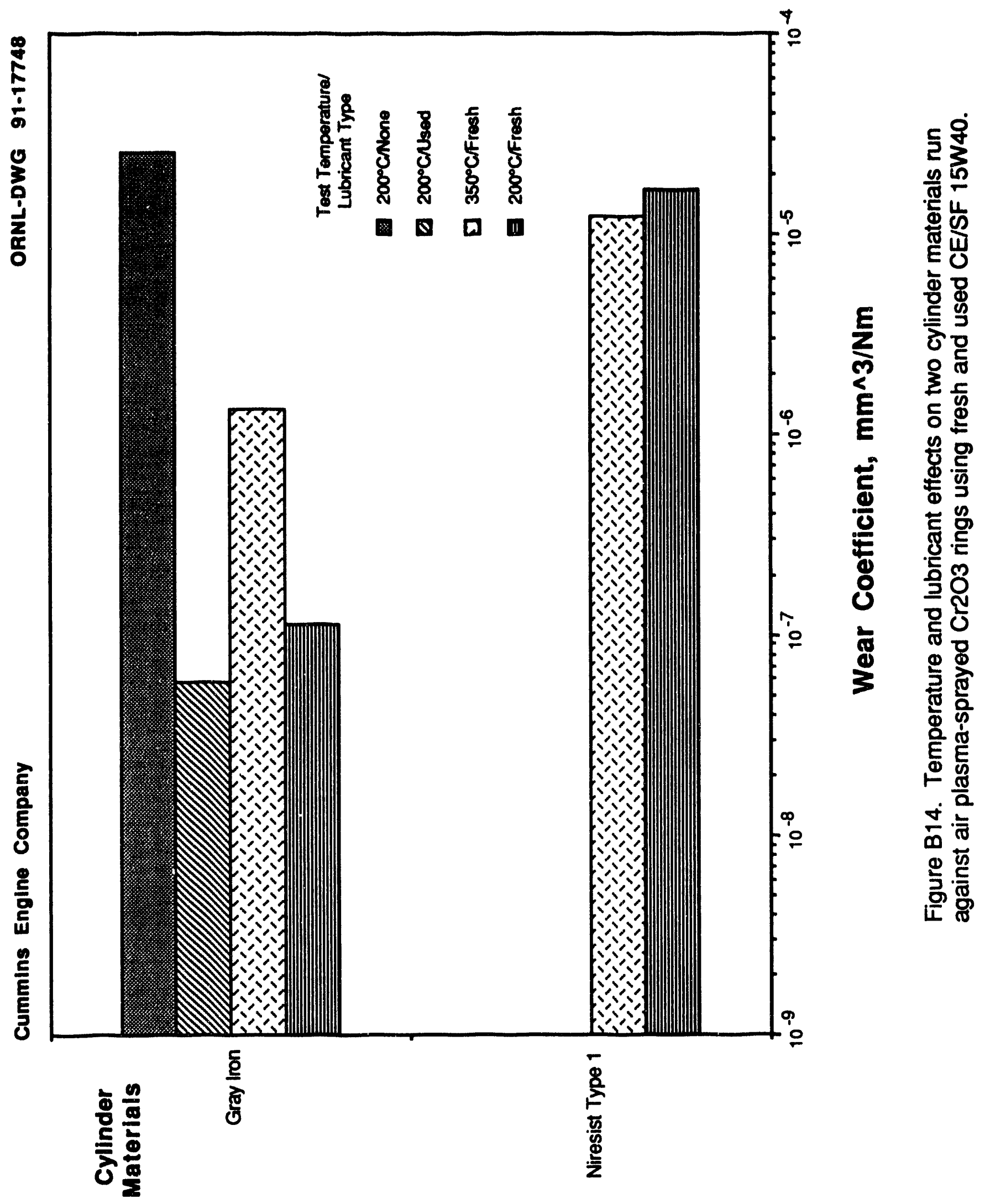




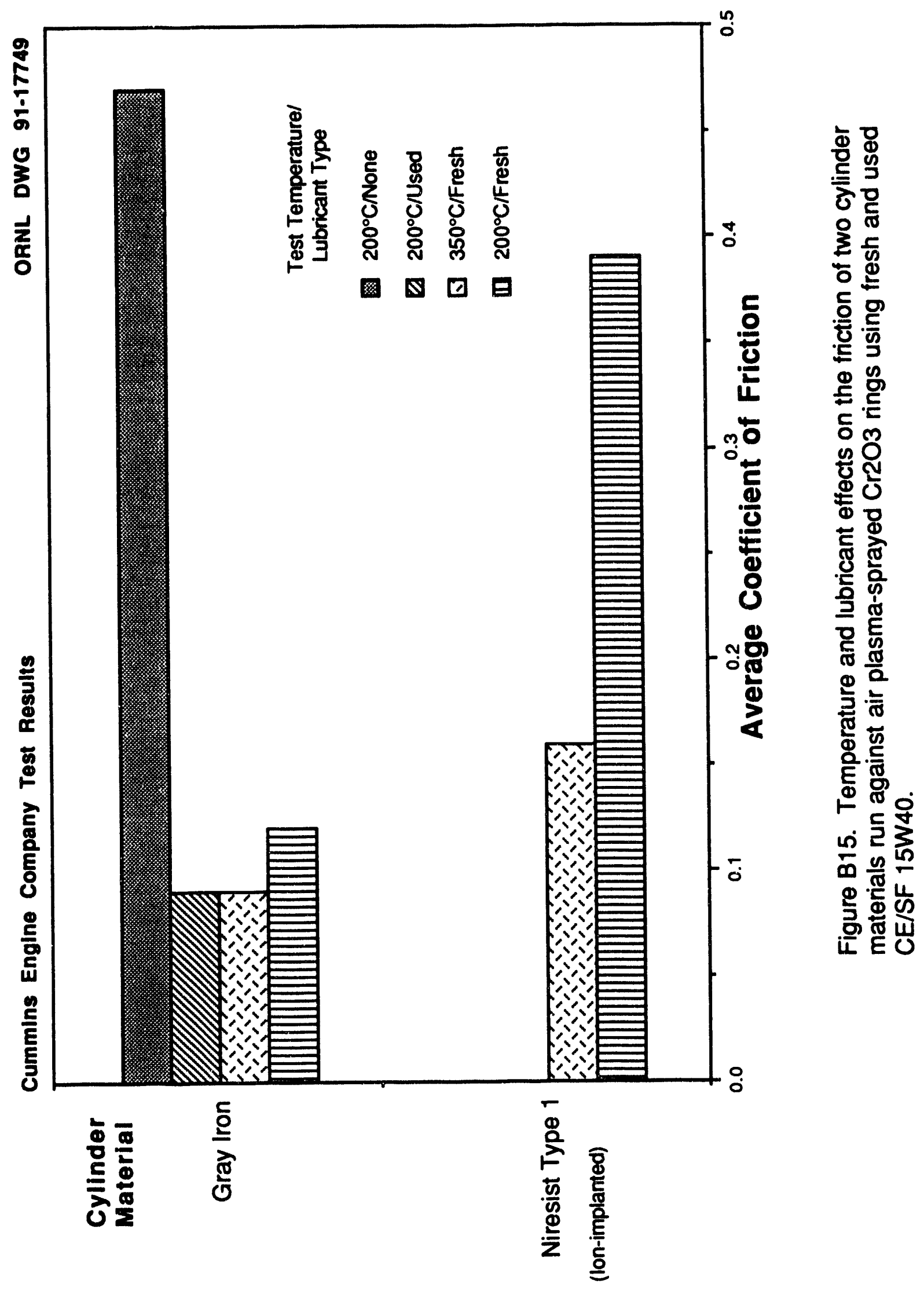


SECTION 3A. INDIVIDUAL TEST NOTES

BATTELLE COLUMBUS LABORATORY TEST NOTES

TEST

TEXT

NUMBER

R4 Good wear resistance, but cylinder specimens' surfaces showed cracking in the contact areas, although these areas were highly polished.

R8 A proprietary surface preparation, CERATEK, was applied by PCK Technology on the silicon nitride cylinder specimens. This process produces an $\mathrm{Au} / \mathrm{Co} / \mathrm{Ni}$ alloy coat bonded to the Si3N4 surface. Mating ring speimens of cobalt-bonded tungsten carbide were used with the special Si3N4 cylinders. Specimen break-in was performed at room temperature and $100 \mathrm{C}$.

R11 After 1 hour break-in at room temperature(20C), ring wear coef.(rwc) was 5.e-06, 1.E-06 after 1 hour at 100C, 3.E-06 after 4 hours at 260C, 7.E-06 after 4 more hours at $260 \mathrm{C}$. Friction coefficient rnage $=0.06$ to 0.16 . The LB625 removed old deposits in test chamber formed by SDL-1, but had higher wear rates in general, possibly due to lack of ZDP, an anti-wear additive found in SDL-1.

R15 Thermo-elastic instability occurred throughout test as visible hot spots.

Cylinger specimens were badly cracked from thermal shock associated with TEI. Cr plating was worn through after 60 minutes of running at $10 \mathrm{~N} / \mathrm{mm}$.

R16 High wear rate was caused by thermo-elastic instability, which showed up as hot spots and streaks on cylinder specimens.

R17 Ring specimens wore $0.05 \mathrm{~mm}$ in 3 minutes of cperation. Surfaces of rings and cylinder specimens were extensively cracked. The edges of ring specimens were chipped away in stair-step cracks following original surface cracks.

R23 Ring and cylinder specimens came from tests on LB625(see test-ids=R32,R26, R30, and R11), thus started life with a 12-hour "break-in". The LB-650X left more deposits with it decomposed, although it was more thermally stable.

R29 High porosity in the ring coatings could be the cause of high wear rates.

R31 High porosity in the ring coatings could be the cause of high wear rates.

R33 The OS-124 burned off very cleanly during the test, but did not seem to have enough usable viscosity left at test temperatures to adequately lubricate the ring/cylinder interface.

R34 Test had to be shut down after 30 minutes due to high friction and higher than normal fluid consumption needed to run quietly. Higher volitility of OS-124 was most likely the reason for need for higher lubrication flow rate. 
SECTION 3A. INDIVIDUAL TEST NOTES, continued BATTELLE COLUMBUS LABORATORY TEST NOTES

TEST

TEXT

NUMBER

R39 This test is a re-test of R29 and R31, using new specimens with better coat-

ings. Quality of the coat does make a difference.

R41 No reliable friction coefficient could be measured due to short duration, but very loud squealing during testing suggests high readings.

R42 No reliable friction coefficients could be measured due to short duration, but very loud squealling during test suggests high readings.

R43 A coating of M501 transferred to the SiC cylinder and the sliding was actually occurring on self-mated M501.

R45 Ring material is M130(alumina-titania) with a molybdenum base coat. Test was stopped when one of the cylinder specimens fractured(due to warpage of its ped-

R47 Ring specimen was wor:- through the $.10 \mathrm{~mm}$ thick $\mathrm{Cr}$ coating to base metal after 1 hour of cperation. Entire test chamber was coated with a tenacious black layer of lubricant decomposition products. The cylinder specimens were grooved, and heavily coated with tenacioys layer of wear debris and lub. decomp. products.

R48 Thermo-elastic instability was observed. $0.05 \mathrm{~mm}$ of the $\mathrm{Cr}$ coating was worn off, and the Z-191 had thermal cracks.

R53 High ring wear rate was caused by thermo-elastic instability, showing up as hot spots and streaks on cylinder specimens.

R54 High wear rate due to thermo-elastic instability, showing up as hot spots and streaks on the cylinder specimens.

R55 Operating speeds varied from 500 to 1500 RPM. Ring load varied from 12 to $18 \mathrm{~N} / \mathrm{mm}$ and coefficient of friction decreased from 0.07 to 0.04 . Original wear was due to "seating of specimens". Hydrodynamic lubrication aided decrease in coefficnt of friction. Some surface smearing and fine abrasion occurred, but no thermal cracks were seen. Ring wear after 4 hours was $0.025 \mathrm{~mm}$. Abrasion scratches in some locations suggest effect of grain orientation on resistance to scratching.

R56 Thermo-elastic instability was observed.

R57 Thermo-elastic instability was observed on the MG-PSZ before the ring specimens fracturec: No h,drodynamic lubrication occurred. 
SECTION 3A. INDIVIDUAL TEST NOTES, continued

BATTELLE COLUMBUS LABORATORY TEST NOTES

TEST

TEXT

NUMBER

R58 No thermo-elastic instability was observed. Rings had slight wear and were highly polished as well as thermal-crack free. Thermal properties of the cylinder appear to be more important than for the rings.

R59 No thermal shock was observed. Edges of the rings were chipped but not fractured

R67 New ring and cylinder specimens were used for this examination of LB-650X.

R62E R62E was run using the same specimen as the other R62 tests, but a different lubricant, LB650X, was used for this part of the test.

R62F R62F was run using the same specimen as the other R62 tests, and the same lubricant, LB650X, used in the R62E test.

R69 Micrograph showed that rough surfaces transferred material and transverse cracks perpendicular to sliding direction were present. The cracks are typical of dry sliding with soft, lubricious coatings.

R71 Test actually ran for less than 10 minutes before ring specimen hoider broke off the sliding arm. Ring specimens shattered, so ring wear coefficient couldn't be measured.

R72 Cylinder wear coefficient was 3.2e-03. Ring coating wore through during test.

R73 Cylinder wear coefficient was 1.2E-02 with 15 micrometers of coating wear. Ring specimen holders broke off after about 10 minutes. A combination of high temps, fatigue and high frictional forces are probable causes of rig failure.

R88 Wear was so high during break-in period that the coating was completeley removed so the test was discontinued.

R90 More oil than usual was needed to keep specimens lubricated. Also, rings loads had to be reduced during the test run.

92LA See text for R92RA.

92RA In this set of tests a normal Si3N4 specimen was mounted in the right ring specimen holder (R92Rn tests) and a $20 \mathrm{Ne}$-ion implanted Si3N4 specimen was placed in the left(R92Ln tests). Both were tested simultaneously using the 3-phase test described in TESTBKGD under BCD-RC3. 


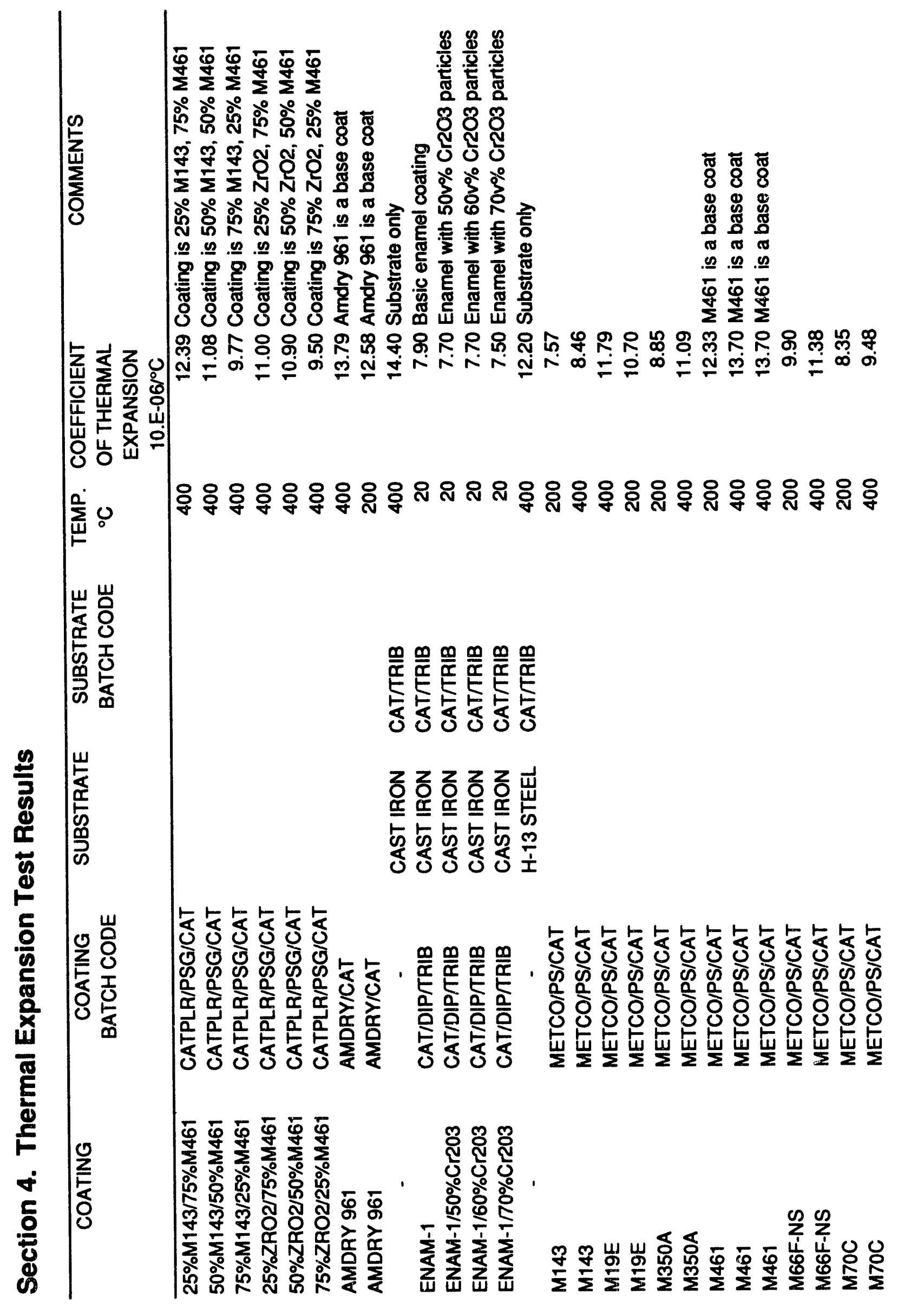




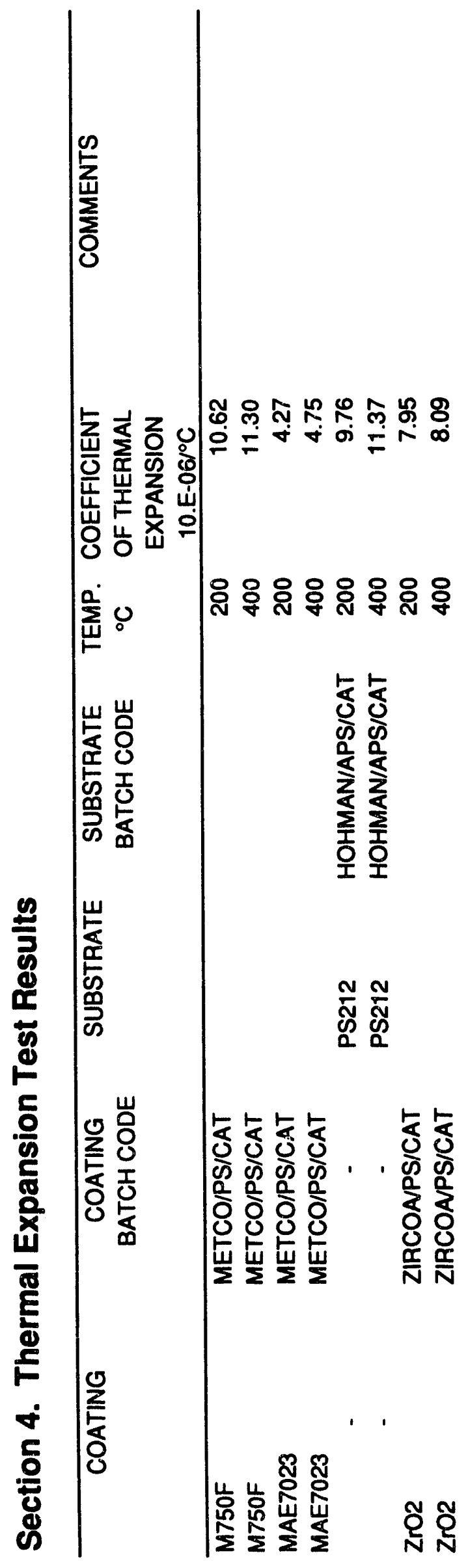




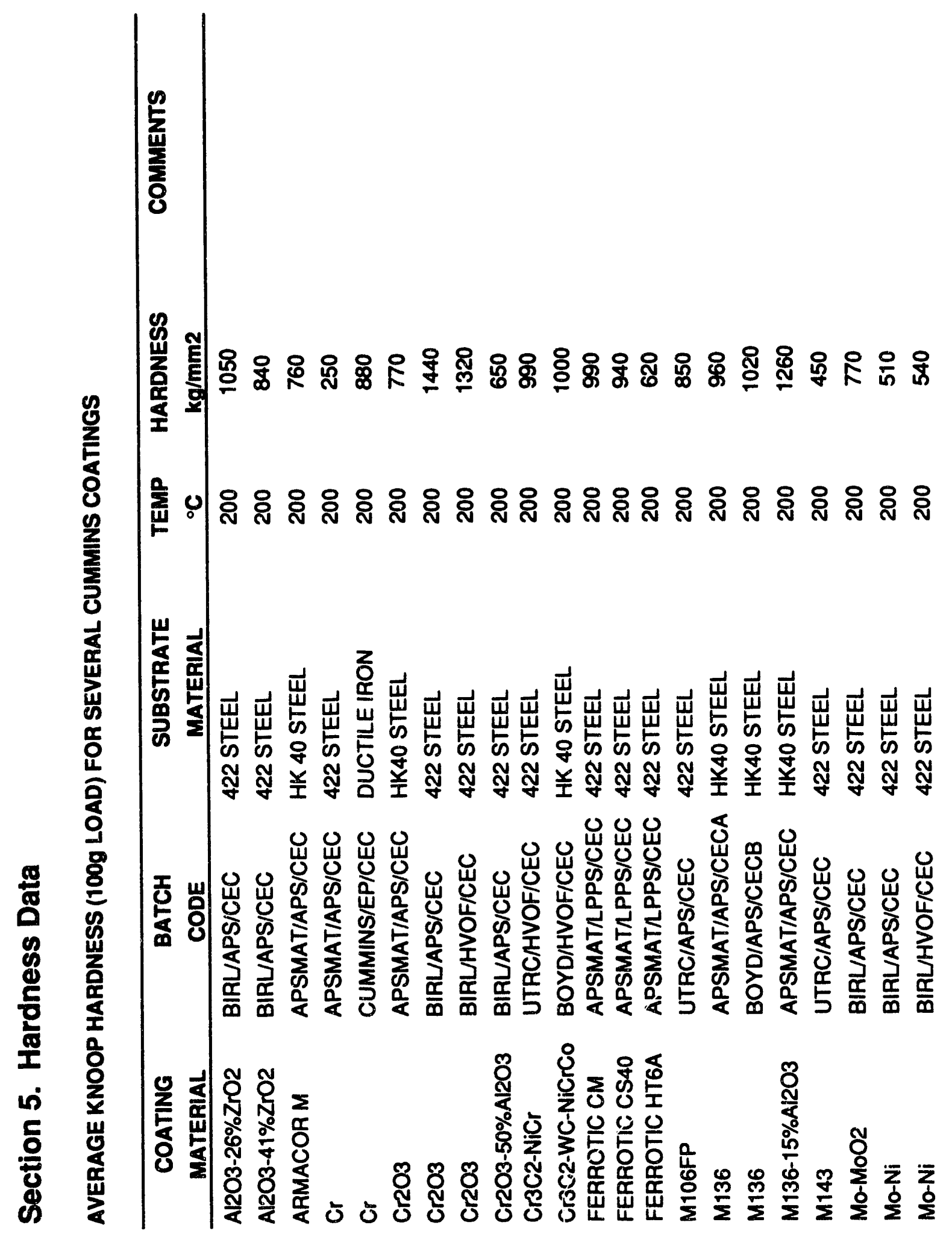




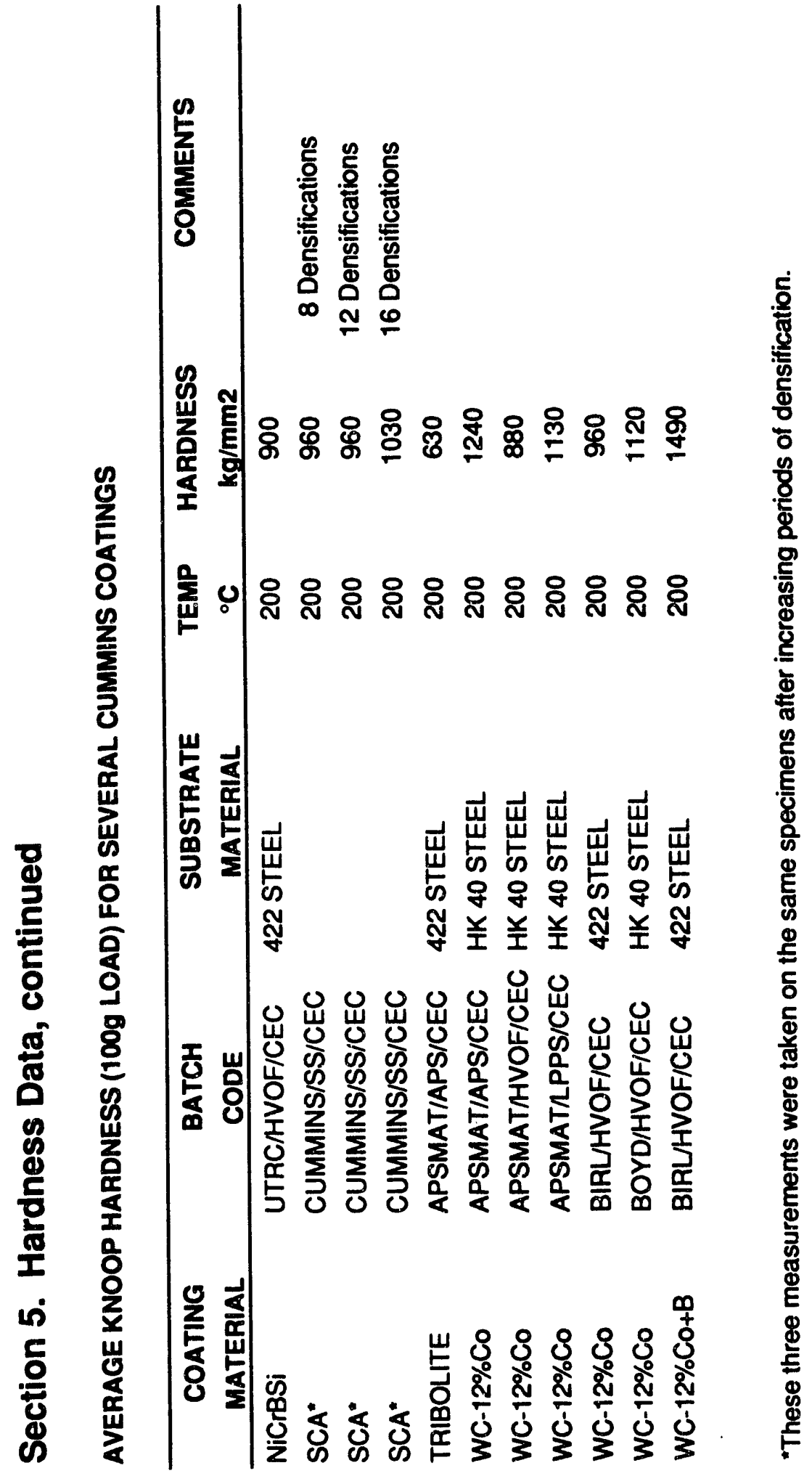


ORNL/M-1862

INTERNAL DISTRIBUTION

1-2. Central Research Library

3. Document Reference Section

4-5. Laboratory Records Department

6. Laboratory Records, ORNL RC

7. ORNL Patent Section

8-10. MAC Records Office

11. L. F. Allard, Jr.

12. L. D. Armstrong

13. P. F. Becher

14. R. F. Bernal

15. T. M. Besmann

16. P. J. Blau

17. A. Bleier

18. E. E. Bloom

19. K. W. Boling

20. R. A. Bradiey

21. C. R. Brinkman

22. V. R. Bullington

23. R. S. Carlsmith

24. P. T. Carlson

25. G. M. Caton

26. S. J. Chang

27. R. H. Cooper, Jr.

28. B. L. Cox

29. D. F. Craig

30. S. A. David

31. J. H. DeVan

32. . J. L. Ding

33. M. K. Ferber

34. F. M. Foust

35. W. Fulkerson

36. R. L. Graves

37. D. L. Greene

38. M. H. Harris

39. E. E. Hoffman

40. C. R. Hubbard

41. M. A. Janney
42. M. G. Jenkins

43. D. R. Johnson

44. W. F. Jones

45. D. Joslin

46. R. R. Judkins

47. M. A. Karnitz

48. M. R. Kass

49-53. B. L. P. Keyes

54. H. D. Kimrey, Jr.

55. T. G. Kollie

56. K. C. Liu

57. E. L. Long, Jr.

58. W. D. Maniy

59. R. H. McClung

60. D. J. McGuire

61. J. R. Merriman

62. D. L. Moses

63. T. A. Molan

64. A. E. Pasto

65. J. L. Rich

66. C. R. Richmond

67. J M Robbins

68. M. L. Santella

69. A. C. Schaffhauser

70. S. Scott

71. G. M. Slaughter

72. E. J. Soderstrom

73. D. P. Stinton

74. R. W. Swindeman

75. V. J. Tennery

76. T. N. Tiegs

77. J. R. Weir, Jr.

78. B. H. West

79. F. W. Wiffen

80. S. G. Winslow

81. J. M. Wyrick

82. C. S. Yust 


\section{EXTERNAL DISTRIBUTION}

83. James H. Adair

University of Florida

Materials Science and

Engineering

317 MAE BIdg.

Gainesville, FL 32611-2066

84. Donald F. Adams

University of Wyoming

Mechanical Engineering

Department

P. O. Box 3295

Laramie, WY 82071

85. Jalees Ahmad

AdTech Systems Research, Inc.

1342 North Fairfield Road

Dayton, OH 45432-2698

86. Yoshio Akimune

NISSAN Motor Co., Ltd.

Materials Research Laboratory

1 Natsushima-Cho

Yokosuka 237

JAPAN AIR MAIL

87. Mufit Akinc

Iowa State University

322 Spedding Hall

Ames, IA 50011

88. Ilhan A. Aksay

University of Washington

Materials Science and Engineering Department, FB-10

Seattle, WA 98195

89. R. G. Alexander

BASE

26 Malvern Close

Kettering Northants NN16 AJP

UNITED KINGDOM AIR MAIL

90. Richard L. Allor

Ford Motor Company

Material Systems

Reliability Department

20000 Rotunda Drive

P.0. Box 2053, Room S-2031

Dearborn, MI 48121-2053
91. Richard T. Alpaugh

U.S. Department of Energy

Advanced Propulsion Division

CE-322, Forrestal Building

Washington, DC 20585

92. Joseph E. Amaral

Instron Corporation

Corporate Engineering Office

100 Royale Street

Canton, MA 02021

93. Edward M. Anderson

Aluminum Company of America

North American Industrial

Chemicals Division

P.0. Box 300

Bauxite, AR 72011

94. Norman C. Anderson

Ceradyne, Inc.

Ceramic-to-Metal Division

3169 Redhill Avenue

Costa Mesa, CA 92626

95. Don Anson

Battelle Columbus Laboratories

Thermal Power Systems

505 King Avenue

Columbus, $\mathrm{OH}$ 43201-2693

96. Thomas Arbanas

G.B.C. Materials Corporation

580 Monastery Drive

Latrobe, PA 15650-2698

97. Frank Armatis

3M Company

3M Center

Building 60-1N-01

St. PauT, MN 55144-1000

98. Everett B. Arnold

Detroit Diesel Corporation

Mechanical Systems Technology

13400 Outer Drive, West

Detroit, MI 48239-4001

99. Richard M. Arons

PA Consulting Group

279 Princeton Road

Hightstown, NJ 08550 
100. Berti1 Aronsson

Sandvik AB

S-12680

Stockholm Lerkrogsvagen 19

SWEDEN AIR MAIL

101. Dennis Assanis

University of Illinois

Department of Mechanical Engineering

1206 W. Green Street

Urbana, IL 61801

102. William H. Atwell

Dow Corning Corporation

3901 South Saginaw Road

MS: 540

Midl and, MI 48686-0995

103. V. S. Avva

North Carolina A\&T State University

Department of Mechanical Engineering

Greensboro, NC 274!1

104. Patrick Badgley

Adiabatics, Inc.

3385 Commerce Drive

Columbus, IN 47201

105. Sunggi Baik

Pohang Institute of Science \& Technology

Department of Materials

Science and Engineering

P.0. Box 125

Pohang 790-600

KOREA AIR MAIL

106. John M. Bailey

Caterpillar, Inc.

Technical Center

Building L

P.0. Box 1875

Peoria, IL 61656-1875

107. Bob Baker

Ceradyne, Inc.

3169 Redhill Avenue

Costa Mesa, CA 92626
108. Frank Baker

Aluminum Company of America

Alcoa Technical Center

Alcoa Center, PA 15069

109. J. G. Baldoni

GTE Laboratories Inc.

40 Sylvan Road

Waltham, MA 02254

110. Clifford P. Ballard

Allied-Signal, Inc.

Ceramics Program

P.0. Box 1021

Morristown, NJ 07962-1021

111. M. Balu

Amoco Performance Products Inc. 4500 McGinnis Ferry Road

Alpharetta, GA 30202

112. B. P. Bandyopadhyay

Toyohashi University of Technology

School of Production Systems Engineering

Tempaku-Cho Toyohashi $\mathbf{4 4 0}$

JAPAN AIR MAIL

113. P. M. Barnard

Ruston Gas Turbines Limited

Metallurgical Laboratory

P. 0. Box 1

Lincoln LN2 50J

ENGLAND AIR MAIL

114. Harold N. Barr

Hittman Corporation

9190 Red Branch Road

Columbia, MD 21045

115. Renald D. Bartoe

Vesuvius McDanel

510 Ninth Avenue

Box 560

Beaver Falls, PA 15010-0560

116. Donald M. Bartos

Dow Corning Corporation

Advanced Ceramics Program

Midland, MI 48686-0995 
117. David L. Baty

Babcock \& Wilcox-LRC

P.0. Box 11165

Lynchburg, VA 24506-1165

118. Donald F. Baxter, Jr.

ASM International

Advanced Materials and

Processes

Materials Park, OH 44073-0002

119. M. Brad Beardsley

Caterpillar, Inc.

Advanced Materials Technology

Technical Center B1dg. E

P.0. Box 1875

Peoria, IL 61656-1875

120. Robert Beck

Teledyne CAE

Materials Engineering/Programs

1330 Laskey Road

P.0. Box 6971

Toledo, OH 43612

121. John C. Bell

Shell Research Limited

Thornton Research Centre

P.0. Box 1

Chester, Ch1 3SH

ENGLAND AIR MAIL

122. Albert H. Bell, III

General Motors Technical Center 30200 Mound Road

Engineering Building/W3 Turbine

Warren, MI 48090-9010

123. M. Bentele

Xamag, Inc.

259 Melville Avenue

Fairfield, CT 06430

124. Larry D. Bentsen

BF Goodrich Company

R\&D Center

9921 Brecksville Road

Brecksville, OH 44141

125. Joseph C. Bentz

ENCERATEC

2525 Sandcrest Drive

Columbus, IN 47203
126. Louis Beregszazi

Defiance Precision Products

P.O. Drawer 428

Defiance, OH 43512

127. Tom Bernecki

Northwestern University

BIRL

1801 Maple Avenue

Evanston, IL 60201-3135

128. Charles F. Bersch

Institute for Defense Analyses

1801 North Beauregard Street

Alexandria, VA 22311

129. Ram Bhatt

NASA Lewis Research Center

21000 Brookpark Road

Clevel and, $\mathrm{OH} \mathbf{4 4 1 3 5}$

130. Deane I. Biehler

Caterpillar, Inc.

Engineering and Research Materials

Technical Center, Building E

P.0. Box 1875

Peoria, IL 61656-1875

131. John. W. Bjerklie

Consolidated Natural Gas

Service Co., Inc.

Research Department

CNG Tower

Pittsburgh, PA 15222-3199

132. William D. Bjorndah1

TRW, Inc.

One Space Park

Building 01, Room 2040

Redondo Beach, CA 90278

133. Keith A. Blakely

Advanced Refractory

Technologies, Inc.

699 Hertel Avenue

Buffalo, NY 14207

134. Edward G. Blanchard

Netzsch Inc.

119 Pickering Way

Exton, PA 19341 
135. Keith 81 andford

Boride Products, Inc.

2879 Aero Park Drive

Traverse City, MI 49684

136. Bruce Boardman

Deere and Company Technical Center

3300 River Drive

Moline, IL 61265

137. Russell Bockstedt

Hoechst Celanese Corporation

150 JFK Parkway

Short Hills, NJ 07078

138. M. Boehmer

DLR German Aerospace Research Establ i shment

Postfach 906058

D-5000 Koln 90

GERMANY AIR MAIL

139. Lawrence P. Boesch

EER Systems Corp.

1593 Spring Hill Road

Vienna, VA 22182-2239

140. Donald H. Boone

Boone \& Associates

2412 Cascade Drive

Walnut Creek, CA 94598-4313

141. Tom Booth

Allied-Signal Aerospace

Company

AiResearch Los Angeles Division

2525 West 190th Street

Torrance, CA 90509-2960

142. Tibor Bornemisza

Sundstrand Power Systems

4400 Ruffin Road

San Diego, CA 92186-5757

143. J.A.M. Boulet

University of Tennessee

Department of Engineering

Science and Mechanics

310 Perkins Hall

Knoxville, TN 37996-2030
144. H. Kent Bowen

Massachusetts Institute of

Technology

77 Massachusetts Avenue

Room E40-434

Cambridge, MA 02139

145. Leslie J. Bowen

Materials Systems

53 Hillcrest Road

Concord, MA 01742

146. Steven C. Boyce

Air Force Office of

Scientific Research

AFOSR/NA BIdg. 410

Bolling AFB DC 20332-6448

147. Gary L. Boyd

CEC

400 Howell Avenue, No. 4

Warl and, WY 82401

148. Steve Bradley

UOP Research Center

50 East Algonquin Road

Des Plaines, IL 60017-6187

149. Michael C. Brands

Cummins Engine Company, Inc.

P.0. Box 3005

Mail Code 50179

Columbus, IN 47201

150. Raymond J. Bratton

Westinghouse Science and

Technology Center

1310 Beulah Road

Pittsburgh, PA 15235

151. John J. Brennan

United Technologies Corporation

Research Center

Silver Lane, MS:24

East Hartford, CT 06108

152. Jeff D. Bright

Ceramatec, Inc.

2425 South 900 West

Salt Lake City, UT 84108 
153. Terrence K. Brog

Coors Ceramics Company

Corporate Development and Technology

4545 McIntyre Street Golden, CO 80403

154. Gunnar Broman

317 Fairlane Drive

Spartanburg, SC 29302

155. Al Brown

High-Tech Materials Alert

P.0. Box 882

Dayton, NJ 08810

156. Jesse Brown

Virginia Polytechnic Institute and State University

Center for Advanced Ceramic Materials

Blacksburg, VA 24061-0256

157. Sherman D. Brown University of Illinois

Materials Science and

Engineering Department

105 South Goodwin Avenue

204 Ceramics Building

Urbana, IL 61801

158. S. L. Bruner

Ceramatec, Inc.

2425 South 900 West

Salt Lake City, UT 84119

159. Adolfo Brusaferro

Keramont Corporation

4231 South Fremont Avenue

Tucson, AZ 85714

160. W. Bryzik

U.S. Army Tank Automotive Command

R\&D Center

Propulsion Systems Division

Warren, MI 48397-5000

161. S. T. Buljan

GTE Laboratories, Inc.

40 Sylvan Road

Waltham, MA 02254
162. S. J. Burden

GTE Valenite

1711 Thunderbird

Troy, MI 48084

163. Curt V. Burkl and

AMERCON, Inc.

8928 Fuilbright Avenue

Chatsworth, CA 91311

164. B111 Bustamante AMERCOM, Inc.

8928 Fullbright Street

Chatsworth, CA 91311

165. Oral Buyukozturk

Massachusetts Institute of Technology

77 Massachusetts Avenue

Room 1-280

Cambridge, MA 02139

166. David A. Caillet

Ethyl Corporation

451 Florida Street

Baton Rouge, LA 70801

167. Frederick J. Calnan

Heany Industries, Inc.

249 Briarwood Lane

P.0. Box 38

Scottsville, NY 14546

168. Roger Cannon

Rutgers University

Ceramics Department

P.0. Box 909

Piscataway, NJ 08855-0909

169. Scott Cannon

P.0. Box 567254

Atlanta, GA 30356

170. Harry W. Carpenter

19945 Acre Street

Northridge, CA 91324

171. David Carruthers

Kyocera Industrial Ceramics Company

P.O. Box 2279

Vancouver, WA 98668-2279 
172. Calvin H. Carter, Jr. Cree Research, Inc. 2810 Meridian Parkway Durham, NC 27713

173. J. David Casey 35 Atlantis Street West Roxbury, MA 02132

174. Jere G. Castor J. C. Enterprise 5078 North 83rd Street Scottsdale, AZ 85250

175. James D. Cawley Case Western Reserve University Materials Science and Engineering Department Cleveland, $\mathrm{OH} 44106$

176. Thomas C. Chadwick Den-Mat Corporation P.0. Box 1729 Santa Maria, CA 93456

177. Ronald H. Chand Chand Kare Technical Ceramics 2 Coppage Drive Worcester, MA 01603

178. Robert E. Chaney EG\&G Idaho, Inc. Idaho National Engineering Laboratory

P.0. Box 1625

Idaho Falls, ID 83415-3525

179. Frank C. Chang

U.S. Army Materials Technology Laboratory

AMTL-EMM

405 Arsenal Street

Watertown, MA 02172

180. Robert M. Chapman

Allied-Signal Aerospace Company

1530 Wilson Boulevard, 10th Floor

Arlington, VA 22209
181. William Chapinan

Williams International

Corporation

2280 Hest Maple Road

Walled Lake, MI 48390-0200

182. Charlie Chen

LECO Corporation

P.0. Box 211688

Augusta, GA 30917

183. Albert A. Chesnes

U.S. Department of Energy

Transportation Technologies

CE-30, Forrestal Building, 6B-094

Washington, DC 20585

184. Kaiyin Chia

Carborundum Company

P.0. Box 832

Niagara Falls, NY 14302

185. Frank Childs

EG\&G Idaho, Inc.

Idaho National Engineering Laboratory

P.0. Box 1625

Idaho Falls, ID 83415-3527

186. Hilliam J. Chmura

Torrington Company

59 Field Street

Torrington, CT 06790-4942

187. Tsu-Hei Chou

University of Delaware

Center for Composite

Materials

201 Spencer Laboratory

Newark, DE 19716

188. R. J. Christopher

Ricardo Consulting Engineers

Bridge Works

Shoreham-By-Sea West Sussex BN43 5FG

ENGLAND AIR MAIL

189. Joel P. Clark

Massachusetts Institute of Technology

Room 8-409

Cambridge, MA 02139 
190. Giorgio Clarotti

Commisston of the European Communities

DGXII-C3, MO75, 1-53;

200 Rue de la Loi

B-1049 Brussels

BELGIUM AIR MAIL

191. W. J. Clegg

ICI Advanced Materials

P.0. Box 11

The Heath, Runcorn Cheshire

WA7 4QE

ENGLAND AIR MAIL

192. Joseph Cleveland

GTE Products Corporation

Hawes Street

Towanda, PA 18848-0504

193. Gloria M. Collins

ASTM

1916 Race Street

Philadelphia, PA 19103

194. Will iam C. Connors Sundstrand Aviation Operations Materials Science and

Engineering Department 4747 Harrison Avenue P.0. Box 7002

Rockford, IL 61125-7002

195. John A. Coppola

Carborundum Company

P.0. Box 156

Niagara Falls, NY 14302

196. Normand D. Corbin

Norton Company

Advanced Ceramics

Goddard Road

Northboro, MA 01532-1545

197. Douglas Corey

Allied-Signal Aerospace

Company

2525 West 190th Street

MS:T52

Torrance, CA 90504-6099
198. Keith P. Costello

Chand/Kare Technical Ceramics

2 Coppage Drive

Worcester, MA 01603-1252

199. Ed L. Courtright

Pacific Northwest Laboratory

MS:K3-59

Richland, WA 99352

200. Anna Cox

Mitchell Market Reports

P.0. Box 23

Monmouth Gwent NP5 4YG

UNITED KINGDOM AIR MAIL

201. Thomas Coyle

Unocal Corporation

Unocal Science \& Technology

Division

376 South Valencia Avenue

Brea, CA 92621

202. Art Cozens

Instron Corporation

3414 Snowden Avenue

Long Beach, CA 90808

203. Robert C. Craft

American Ceramic Society, Inc.

757 Brooksedge Plaza Drive Westerville, $\mathrm{OH} 43081$

204. Mark Crawford

New Technology Week

4604 Monterey Drive

Annandale, VA 22003

205. Richard A. Cree

Markets \& Products, Inc.

P.0. Box 14328

Columbus, $\mathrm{OH}$ 43214-0328

206. Les Crittenden

Vesuvius McDane1

Box 560

Beaver Falls, PA 15010 
207. William J. Croft

U.S. Army Materials

Technology Laboratory

405 Arsenal Street

Watertown, MA 02172

208. M. J. Cronin

Mechanical Technology, Inc.

968 Albany-Shaker Road

Latham, NY 12110

209. Gary M. Crosbie

Ford Motor Company

1430 Culver Avenue

S-2079, SRL Building

Dearborn, MI 48121-4036

210. Floyd W. Crouse, Jr.

U.S. Department of Energy

Morgantown Energy

Technology Center

Collins Ferry Road

P.0. Box 880

Morgantown, WV 26505

211. John Cuccio

Allied-Signal Aerospace Company

Garrett Auxiliary Power Division

P.0. Box 5227, MS:1302-2Q

Phoenix, AZ 85010

212. Raymond Cutler

Ceramatec, Inc.

2425 South 900 West

Salt Lake City, UT 84119

213. Charles D'Angelo

GTE Laboratories, Inc.

40 Sylvan Road

Waltham, MA 02154

214. Stephen C. Danforth

Rutgers University

Ceramic Engineering Department

P.0. Box 909

Piscataway, NJ 08855-0909
215. Sankar Das Gupta

Electrofuel Manufacturing Co., L.td.

9 Hanna Avenue

Toronto Ontario MGK-1W8

CANADA AIR MAIL

216. Charles Davis

Sverdrup Technology, Inc., MSFC

620 Discovery Drive

Huntsville, AL 35806

217. Frank Davis

Allied Signal Aerospace Co.

7550 Lucerne Dr., \# 203

Middleburg Heights, $\mathrm{OH} 44130$

218. Robert F. Davis

North Carolina State University

Materialls Engineering Department

229 Riddick Laboratory

P.0. Box 7907

Raleigh, NC 27695

219. Thomas DeAngelis

Carborundum Company

Niagara Falls R\&D Center

P.0. Box 832

Niagara Falls, NY 14302

220. George DeBell

Ford Motor Company

Material Systems Reliability Department

20000 Rotunda Drive

P.O. Box 2053, Room S-2023

Dearborn, MI 48121-2053

221. Michael Deluca

AMP-AKZO

West Lane

Aquebogue, 11931

222. Gerald L. DePoorter

Colorado School of Mines

Metallurgical and Materials

Engineering Department

Golden, CO 80401 
223. J. F. DeRidder

Omini Electro Motive, Inc., 12 Seely Hill Road

Newfield, NY 14867

224. Nick C. Dellow

Materials Technology

Publications

40 Sotheron Road

Watford Herts WD1 2QA

UNITED KINGDOM AIR MAIL

225. L. R. Dharani

University of Missouri-Rolla

224 M.E.

Rolla, MO 65401

226. Douglas A. Dickerson

Union Carbide Specialty

Powders

1555 Main Street

Indianapolis, IN 46224

227. John Dodsworth

Vesuvius Research \& Development.

Technical Ceramics Group

Box 560

Beaver Falls, PA 15010

228. B. Dogan

Institut fur Werkstofforschung

GKSS-Forschungszentrum Geesthacht GmbH

Max-Pl anck-Strasse

D-2054 Geesthacht

GERMANY AIR MAIL

229. Jean-Marie Drapier

FN Moteurs S.A.

Material and Processing

B-4041 Milmort (Herstal)

BELGIUM AIR MAIL

230. Kenneth C. Dreitlein

United Technologies

Research Center

Silver Lane

East Hartford, CT 06108
231. Robin A.L. Orew

McGill University

Department of Mining and

Metallurgical Engineering

3450 University Street

Montreal Quebec H3A 2A7

CANADA AIR MAIL

232. Winston H. Duckworth

$\mathrm{BCL}$

Columbus Division

505 King Avenue

Columbus, OH 43201-2693

233. Edmund M. Dunn

Texel Company

6 Third Street

Lexington, MA 02173

234. Bill Durako

Sundstrand Aviation Operations

Department 789-6

4747 Harrison Avenue

P.0. 7002

Rockford, IL 61125-7002

235. Ernest J. Duwe11

212 E7m Street

Hudson, WI 54016

236. Chuck J. Dziedzic

Coors Ceramics Company

Structural Pruducts Group

17750 West 32nd Avenue

Golden, CO 80401

237. Robert J. Eagan

Sandia National Laboratories

Engineered Materials \& Processes Center

Org 1700

P.0. Box 5800

Albuquerque, NM 87185-5800

238. Jeffrey Eagleson

Lanxide Corporation

1001 Connecticut Avenue, N.W. Washington, DC 20036 
239. Harry E. Eaton

United Technologies Corporation

Research Center

Silver Lane

East Hartford, CT 06108

240. Harvill C. Eaton

Louisiana State

University

Office of Research and Economic Development

240 Thomas Boyd Hall

Baton Rouge, LA 70803

241. Christopher A. Ebel

Carborundum Company

Technology Division

P.0. Box 337

Niagara Falls, NY 14302

242. J. J. Eberhardt

U.S. Department of Energy

Office of Transportation Materials

CE-34, Forrestal Building

Washington, DC 20585

243. Jim Edler

Eaton Corporation

26201 Northwestern

Highway

P.0. Box 766

Southfield, MI 48037

244. William A. Ellingson

Argonne National Laboratory

Materials Science \& Technology Division

9700 South Cass Avenue

Argonne, IL 60439

245. William S. Ellis

Machined Ceramics

629 N. Graham St.

N. Industrial Park

Bowling Green, KY 42101

246. Gien B. Engle

Nuclear \& Aerospace Materials

Corporation

16716 Martincoit Road

Poway, CA 92064
247. Jeff Epstein

Ceramic Technologies, Inc.

2107 Jamara Lane

Houston, TX 77077

248. Kenneth A. Epstein

Dow Chemical U.S.A.

Ceramics and Advanced

Materials

800 Building

Midl and, MI 48667

249. Art Erdemir

Argonne National Laboratory

Materials and Components

Technology Division

9700 South Cass Avenue

Argonne, IL 60439

250. E. M. Erwin

Lubrizol Corporation

1819 East 225th Street

Euclid, OH 44117

251. Kenji Esaki

Toyota Technical Center

U.S.A., Inc.

2000 Town Center, Suite 500

Southfield, MI 48075

252. Jose L. Escalante

Anglo-Mex-Tech. Inc.

3923 N.W. 24th Street

Miami, FL 33142

253. John N. Eustis

U.S. Department of Energy

Industrial Energy Efficiency

Division

CE-221, Forrestal Building

Washington, DC 20585

254. Robert C. Evans

NASA Lewis Research Center

Terrestrial Propulsion Office

21000 Brookpark Road, MS: 86-6

Cleveland, $\mathrm{OH} 44135$

255. W. L. Everitt

Kyocera International, Inc.

8611 Balboa Avenue

San Diego, CA 92123 
256. Gordon Q. Evison

332 South Michigan Avenue

Suite 1730

Chicago, IL 60604

257. John W. Fairbanks

U.S. Department of Energy

Advanced Propulsion Division

CE-322, Forrestal Building

Washington, DC 20585

258. Tim Fawcett

Dow Chemical Company

Central Research, Advanced

Ceramics Laboratory

1776 Building

Midl and, MI 48674

259. Robert W. Fawley

Sundstrand Power Systems

Division of Sundstrand

Corporation

4400 Ruffin Road

P.0. Box 85757

San Diego, CA 92186-5757

260. John J. Fedorchak

GTE Products Corporation

Hawes Street

Towanda, PA 18848-0504

261. Jeff T. Fenton

Vista Chemical Company

900 Threadneedle

Houston, TX 77079

262. Larry Ferrell

Babcock \& Wilcox

0ld Forest Road

Lynchburg, VA 24505

263. Raymond R. Fessler

BIRL

Industrial Research Lab

1801 Maple Avenue

Evanston, IL 60201

264. Michelle Finch

E. I. DuPont de Nemours \& Company, Inc.

Experimental Station

Information Center E302/301

Wilmington, DE 19898
265. Arthur D. Fine

United Technologies Corporation

Pratt \& Whitney Aircraft

400 Main Street

MS: $163-10$

East Hartford, CT 06108

266. Ross F. Firestone

Ross Firestone Company

188 Mary Street

Winnetka, IL 60093-1520

267. Sharon L. Fletcher

Arthur D. Little, Inc.

15 Acorn Park

Cambridge, MA 02140-2390

268. Thomas F. Foltz

Textron Specialty Materials

2 Industrial Avenue

Lowell, MA 01851

269. Renee G. Ford

Materials and Processing Report

P.0. Box 72

Harrison, NY 10528

270. John Formica

Supermaterials

2020 Lakeside Avenue

Clevel and, $\mathrm{OH} 44114$

271. Jennifer M. Fox

Dyson Refractories Limited

R\&D Laboratory

Owler Bar

Sheffield S17 3BJ

UNITED KINGDOM

AIR MAIL

272. Edwin Frame

Southwest Research Institute

Division 2

P.0. Drawer 28510

San Antonio, TX 78284

273. Armanet Francois

French Scientific Mission

4101 Reservoir Road, N.W.

Washington DC 20007-2176

274. R. G. Frank

Technology Assessment Group 10793 Bentley Pass Lane

Lovel and, $\mathrm{OH} 45140$ 
275. David J. Franus

Forecast International

22 Commerce Road

Newtown, CT 06470

276. Marc R. Freedman

NASA Lewis Research Center

21000 Brookpark Road

MS: 49-3

Cleveland, $\mathrm{OH} 44135$

277. Douglas Freitag

LTV Missiles Division

P.0. Box 650003

MS:WT-21

Dallas, TX 75265

278. Brian R.T. Frost

Argonne National Laboratory

9700 South Cass Avenue

Building 900

Argonne, IL 60439

279. Lawrence R. Frost

Instron Corporation

100 Royall Street

Canton, MA 02021

280. George A. Fryburg

Norton/TRW Ceramics

7A-4 Raymond Avenue

Salem, NH 03079

281. Xiren $\mathrm{Fu}$

Shanghai Institute of Ceramics

Chinese Academy of Sciences

1295 Ding-xi Road

Shanghai 200050

CHINA AIR MAIL

282. John Gahimer

P.0. Box 1302

Dubl in, $\mathrm{OH} 43017$

283. J. P. Gallagher

University of Dayton Research Institute

300 College Park, JPC-250

Dayton, OH 45469-0120
284. Tom Garritano

University of Tennessee

Science Alliance

101 South College

Knoxville, TN 37996-1328

285. Joy A. Garwood

Norton Company

Advanced Ceramics

Goddard Road

Northboro, MA 01532-1545

286. H. Maury Gatewood

Reynolds Metals Company Corporate R\&D

Fourth and Canal Streets

P.0. Box 27003

Richmond, VA 23261

287. L. J. Gauckler

ETH-Zurich

Sonneggstrasse 5

CH-8092 Zurich 8092

SWITZERLAND AIR MAIL

288. Peter A. Gaydos

Battelle Columbus Laboratories

505 King Avenue

Columbus, $\mathrm{OH} 43201$

289. George E. Gazza

U.S. Army Materials

Technology Laboratory

Ceramics Research Division

405 Arsenal Street

Watertown, MA 02172-0001

290. D. Gerster

CEA-DCOM

33 Rue De La Federation

Paris 75015

FRANCE AIR MAIL

291. John Ghinazzi

Coors Technical Ceramics Company

1100 Commerce Park Drive

Oak Ridge, TN 37830 
292. Robert Giddings

General Electric Company

Research Laboratory

P.0. Box 8

Schenectady, NY 12301

293. A. M. Glaeser

University of California

Materials Science and Mineral

Engineering

Lawrence Berkeley Laboratory

Hearst Mining Building

Berkeley, CA 94720

294. Paul Glance

Concept Analysis

R\&D

950 Stephenson Highway

Dupont Automotive Development Building

Troy, MI 48007-7013

295. Joseph W. GIatz

Naval Air Propulsion Center

Systems Engineering Division

P.0. Box 7176, PE24

Trenton, NJ 08628

296. H. M. Goldberger

Superior Graphite Company

R\&D

2175 East Broad Street

Columbus, $\mathrm{OH} 43209$

297. Allan E. Goldman

U.S. Graphite, Inc.

907 West Outer Drive

Oak Ridge, TN 37830

298. Stephen T. Gonczy

Allied Signal Research

P.0. Box 5016

Des Plaines, IL 60017

299. Jeffrey M. Gonzales

GTE Products Corporation

Hawes Street

Towanda, PA 18848-0504

300. Robert J. Gottschall

U.S. Department of Energy

ER-131, MS:G-236

Washington, DC 20545
301. Earl Graham

Cleveland State University

Department of Chemical Engineering

Euclid Avenue at East 24th Street

Cleveland, OH 44115

302. Hilliam A. Graham Lanxide Corporation P.0. Box 6077

Newark, DE 19714-6077

303. Robert E. Green, Jr. Johns Hopkins University Materials Science and Engineering Department Battimore, MD 21218

304. Lance Groseclose

General Motors Corporation Allison Gas Turbine Division P.O. Box 420, MS:H-5 Indianapolis, IN 46206

305. Mark F. Gruninger

Union Carbide Corporation

Specialty Powder Business 1555 Main Street Indianapolis, IN 46224

306. Ernst Guge]

Cremer Forschungsinstitut GmbH\&Co.KG

Oeslauer Strasse 35

D-8633 Roedental 8633

GERMANY AIR MAIL

307. Donald L. Guile

Corning Glass Works

SP-DV-1-9

Corning, NY 14831

308. Bimleshwar P. Gupta

Solar Energy Research Institute

Mechanical and Industrial Technology Division

1617 Cole Boulevard

Golden, CO 80401 
309. John P. Gyekenyesi

NASA Lewis Research Center 21000 Brookpark Road, MS:6-1

Cleveland, OH 44135

310. Nabil S. Hakim Detroit Diesel Corporation 13400 West Outer Drive Detroit, MI 48239

311. Philip J. Haley General Motors Corporation Vehicular Engineering P.0. Box 420, MS:T12A Indianapol is, IN 46236

312. Judith Hall

Fiber Materials, Inc.

Biddeford Industrial Park 5 Morin Street Biddeford, ME 04005

313. Y. Harada

IIT Research Institute Nometallic Materials and Composites 10 West 35th Street Chicago, IL 60616

314. R. A. Harmon 25 Schalren Drive Latham, NY 12110

315. Amy Harmon-Barrett Martin Marietta Laboratories 1450 South Rolling Road Baitimore, MD 21227

316. Norman H. Harris Hughes Aircraft Company P.0. Box 800520 Saugus, CA 91380-0520

317. Alan Hart Dow Chemical Company Advanced Ceramics Laboratory 1776 Building

Midland, MI 48674
318. Pat E. Hart

Battelle Pacific Northwest Laboratories

Ceramics and Polymers Development Section

P.O. Box 999

Richland, WA 99352

319. Stephen D. Hartline Norton Company Advanced Ceramics Goddard Road Northboro, MA 01532-1545

320. Michael H. Haselkorn Caterpillar, Inc.

Engineering Research Materials Technical Center, Building $E$ P.0. Box 1875

Peoria, IL 61656-1875

321. N. B. Havewala

Corning, Inc. SP-PR-11 Corning, NY 14831

322. John Haygarth

Teledyne WAA Chang Albany P.0. Box 460

ATbany, OR 97321

323. Norman L. Hecht University of Dayton Research Institute 300 College Park Dayton, OH 45469-0172

324. Peter W. Heitman General Motors Corporation Allison Gas Turbine Division P.0. Box 420, MS:W-5 Indianapol is, IN 46206-0420

325. Robert W. Hendricks

Virginia Polytechnic Institute and State University

Materials Engineering Department

210 Holden Hall

B1 acksburg, VA 24061-0237 
326. Wynne Henley Hertel Cutting Technologies, Inc. 1000 Clearview Court

Oak Ridge, TN 37830

327. Thomas L. Henson GTE Products Corporation

Chemical \& Metallurgical Division Hawes Street Towanda, PA 18848

328. Thomas P. Herbell NASA Lewis Research Center 21000 Brookpark Road

MS: 49-3

Clevel and, $\mathrm{OH} 44135$

329. Marlene Heroux

Rolls-Royce, Inc.

2849 Paces Ferry Road

Suite 450

Atlanta, GA 30339-3769

330. Robert L. Hershey

Science Management Corporation

1255 New Hampshire Ave., N.W.

Suite 1033

Washington, DC 20036

331. Hendrik Heystek

Bureau of Mines

Tuscaloosa Research Center P.0. Box L

University, AL 35486

332. Wallace C. Higgins

Norwal Unlimited

P.0. Box 1258

Alfred, NY 14802

333. Robert V. Hillery

GE Aircraft Engines

One Neumann Way, M.D. H85

Cincinnati, $\mathrm{OH} 45215$

334. Arthur Hindman

Instron Corporation

100 Royall Street

Canton, MA 02021
335. Jon Hines

American Ceramic Society, Inc.

757 Brooksedge Plaza Drive

Westerville, OH 43081-6136

336. Hans Erich Hintermann

CSEM

Materials and Micromechanics

Division

Rue Breguet 2

Neuchatel 2000

SWITZERLAND AIR MAIL

337. Shinichi Hirano

Mazda R\&D of North America, Inc.

1203 Hoodridge Avenue

Ann Arbor, MI 48105

338. Tommy Hiraoka

NGK Locke, Inc.

1000 Town Center

Southfield, MI 48075

339. John M. Hobday

U.S. Department of Energy

Morgantown Energy Technology Center

Collins Ferry Road

P.0. Box 880

Morgantown, WV 26507

340. Greg Hoenes

Vista Chemical Company

900 Threadneedle

P.0. Box 19029

Houston, TX 77079-2990

341. Clarence Hoenig

Lawrence Livermore National Laboratory

P.0. Box 808, Mail Code L-369

Livermore, CA 94550

342. Thomas Hollstein

Fraunhofer-Institut fur Werkst offmechanik IWM

Wohlerstrabe 11

D-7800 Freiburg

GERMANY AIR MAIL 
343. Richard Holt

National Research Council of Canada

Strurtures and Materials Laboratory Ottawa Ontario K1A OR6 CANADA AIR MAIL

344. Joseph Homeny University of Illinois

Department of Materials Science and Engineering

105 South Goodwin Avenue

Ceramics Building

Urbana, IL 61801

345. A. T. Hopper

Battelie Columbus

Laboratories

Metals and Ceramics Department

505 King Avenue

Columbus, OH 43201-2693

346. Michael Horgan

Materials Engineering Magazine

1100 Superior Avenue

Cleveland, OH 44114

347. Woodie Howe

Coors Technical Ceramics

Company

1100 Commerce Park Drive

Oak Ridge, TN 37830

348. Stephen M. Hsu

National Institute of

Standards and Technology

Gaithersburg, MD 20899

349. Hann S. Huang

Argonne National Laboratory

9700 South Cass Avenue

Argonne, IL 60439-4815

350. Gene Huber

Precision Ferrites \& Ceramics

5576 Corporate Drive

Cypress, CA 90630

351. M. L. Huckabee

GTE Laboratories, Inc.

40 Sylvan Road

Waltham, MA 02254
352. Harold A. Huckins

Princeton Advanced

Technology, Inc.

56 Finley Road

Princeton, NJ 08540

353. Fred R. Huettic

Advanced Magnetics, Inc.

45 Corey Lane

Mendham, NJ 07945

354. Bill Huffman

Zircar

110 North Main Street

Florida, NY 10921

355. Brian K. Humphrey

Lubrizol Petroleum

Chemicals Co.

3000 Town Center, Suite 1340

Southfield, MI 48075-1201

356. Robert M. Humrick

Dylon Ceramic Technologies

3100 Edgehill Road

Cleveland Heights, $\mathrm{OH} 44118$

357. Lorretta Inglehart

National Science Foundation

Division of Materials Research

1800 "G" Street, N.W.,

Room 408

Washington, DC 20550

358. Michael S. Inoue

Kyocera International, Inc.

KII Library

8611 Balboa Avenue

San Diego, CA 92123-1580

359. Osama Jadaan

University of WisconsinPlatteville

General Engineering Division

1 University Plaza

Platteville, WI 53818

360. Curtis A. Johnson

General Electric Company

Corporate R\&D

Room MB-187

P.0. Box 8

Schenectady, NY 12301 
361. Sylvia Johnson

SRI International

333 Ravenswood Avenue

Menlo Park, CA 94025

362. Thomas A. Johnson

Lanxide Corporation

1300 Marrows Road

P.0. Box 6077

Newark, DE 19714-6077

363. H. S. Johnson

Indiana University

One City Centre, Suite 200

Bloomington, IN 47405

364. Jill E. Jonkouski

U.S. Department of Energy

9800 South Cass Avenue

Argonne, IL 60439-4899

365. L. A. Joo

Great Lakes Research

Corporation

P.0. Box 1031

Elizabethton, TN 37643

366. A. D. Joseph

SPX Corporation

700 Terrace Point

Muskegon, MI 49443

367. Adam Jostsons

Australian Nuclear Science \& Technology Organization

Lucas Heights Research Laboratories

New Illawarra Road

Lucas Heights New South Wales

AUSTRALIA AIR MAIL

368. Matthew K. Juneau

Ethyl Corporation

451 Florida Street

Baton Rouge, LA 70801

369. Hartmut Kainer

Didier-Werke AG

Anlagentechnik Wiesbaden

Abraham-Lincoln-Str. 16

$D-62$ Viesbaden

GERMANY AIR MAIL
370. Tom Kalamasz

Norton/TRW Ceramics

$7 A-4$ Raymond Avenue

Salem, NH 03079

371. Lyle R. Kallenbach

Phillips Petroleum Company

R\&D

Mail Drop:123AL

Bartlesvilie, OK 74004

372. Nick Kamiya

Kyocera Industrial Ceramics Corporation

2700 River Road

Des Plaines, IL 60018

373. Roy Kamo

Adiabatics, Inc.

3385 Commerce Park Drive

Columbus, IN 47201

374. S. Kang

GTE Laboratories, Inc.

40 Sylvan Road

Waltham, MA 02254

375. Chih-Chun Kao

Industrial Technology Research Institute

Materials Research Laboratories

195 Chung-Hsing Road, Sec. 4

Chutung Hsinchu 31015 R.0.C.

TAIWAN AIR MAIL

376. Keith R. Karasek

Allied-Signal, Inc.

Engineered Materials Research Center

50 East Algonquin Road

P.0. Box 5016

Des Plaines, IL 60017-5016

377. Robert E. Kassel

Ceradyne, Inc.

3169 Redhill Avenue

Costa Mesa, CA 92626

378. Allan Katz

Wright Laboratory

Metals and Ceramics Division

WL/MLLM

Wright-Patterson AFB, OH 45433 
379. R. Nathan Katz

Worcester Polytechnic Institute

Dept. of Mechanical

Engineering

100 Institute Road

Worcester, MA 01609

380. Ted Kawaguchi

Tokai Carbon America, Inc.

375 Park Avenue, Suite 3802

New York, NY 10152

381. Noritsugu Kawashima

TOSHIBA Corporation

Mechanical Engineering Laboratory

4-1 Ukishima-Cho

Kawasaki-Ku Kawasaki 210

JAPAN AIR MAIL

382. Lisa Kempfer

Penton Publishing

Materials Engineering

1100 Superior Avenue

Clevel and, $\mathrm{OH}$ 44114-2543

383. Frederick L. Kennard, III

General Motors Corporation

AC Rochester

Department 32-24, EB

1300 North Dort Highway

Flint, MI 48556

384. David 0. Kennedy

Lester B. Knight Cast

Metals Inc.

549 West Randolph Street

Chicago, IL 60661

385. George Keros

Photon Physics

3175 Penobscot Building

Uetroit, MI 48226

386. Pramod K. Khandelwal

General Motors Corporation

Allison Gas Turbine

Division

P.0. Box 420, MS:W05

Indianapolis, IN 46206
387. Jim R. Kidwell

Allied-Sigual Aerospace Company

Garrett Auxiliary Power Division

P.0. Box 5227

Phoenix, AZ 85010

388. Han J. Kim

GTE Laboratories, Inc.

40 Sylvan Road

Waltham, MA 02254

389. Shin Kim

Korea Institute of Machinery

\& Metals

66 Sangnam-dong, Changwon

Kyungnam 641-010

KOREA AIR MAIL

390. W. C. King

Mack Truck, Z-41

1999 Pennsylvania Avenue

Hagerstown, MD 21740

391. Carol Kirkpatrick

MSE, Inc.

CDIF Technical Library

P.0. Box 3767

Butte, MT 59702

392. Tony Kirn

Caterpillar, Inc.

Defense Products Department, JB7

Peoria, IL 61629

393. James D. Kiser

NASA Lewis Research Center

21000 Brookpark Road, MS:49-3

Cleveland, $\mathrm{OH} 44135$

394. Max Klein

Gas Research Institute

Thermodynamics

8600 West Bryn Mawr Avenue

Chicago, IL 60631

395. Richard N. Kleiner

Coors Ceramics Company

4545 McIntyre Street

Golden, CO 80403 
396. Stanley J. Klima

NASA Lewis Research Center 21000 Brookpark Road

MS:6-1

Cleveland, OH 44135

397. Chris E. Knapp

Norton Advanced Ceramics

of Canada Ltd.

8001 Daly Street

Hiagara Falls, Ontario L2G 6S2

CANADA AIR MAIL

398. Albert S. Kobayashi

University of Washington

Mechanical Engineering Department

MS:FU10

Seattle, WA 98195

399. Shigeki Kobayashi

Toyota Central Research Labs, Inc.

Nagakute Aichi 480-11

JAPAN AIR MAIL

400. Richard A. Kole

Z-Tech Corporation

8 Dow Road

Bow, NH 03304

401. E. Kostiner

University of Connecticut

Chemistry Department, U-60

Storrs, CT 06269-3060

402. Kenneth A. Kovaly

Technical Insights, Inc.

P.0. Box 1304

Fort Lee, NJ 07024-9967

403. Ralph G. Kraft

Spraying Systems Company North Avenue at Schmale Road Wheaton, IL 60189-7900

404. Saunders B. Kramer

U.S. Department of Energy

Advanced Propulsion Division CE-322, Forrestal Building Washington, DC 20585
405. Arthur Kranish

Trends Publishing, Inc.

1079 National Press Building

Washington, DC 20045

406. A. S. Krieger

Radiation Science, Inc.

P.0. Box 293

Belmont, MA 02178

407. Pieter Krijgsman

Ceramic Design International Holding B.V.

P.0. Box 68

Hattem 8050-AB

THE NETHERLANDS AIR MAIL

408. Waltraud M. Kriven

University of Illinois

Materials Science and

Engineering Department

105 South Goodwin Avenue

Urbana, IL 61801

409. Edward J. Kubel, Jr.

ASM International Advanced Materials \& Processes

Materials Park, OH 44073

410. Dave Kupperman

Argonne National Laboratory

9700 South Cass Avenue

Argonne, IL 60439

411. Oh-Hun Kwon

Norton Company

Advanced Ceramics

Goddard Road

Northboro, MA 01532-1545

412. W. J. Lackey

Georgia Institute of Technology

Materials Science and

Technology

Atlanta, GA 30332

413. Jai Lala

Tenmat Ltd.

40 Somers Road

Rugby Narwickshire CV22 7DH

ENGLAND AIR MAIL 
414. Hari S. Lamba

General Motors Corporation

Electro-Motive Division

9301 West 55th Street

LaGrange, IL 60525

415. Richard L. Landingham

Lawrence Livermore National Laboratory

Ceramics, Corrosion, and Thermochemistry

P.0. Box 808, L-369

Livermore, CA 94550

416. Charles J. Landry

Chand Kare Technical Ceramics

712 Flat Hill Road

Lumenburg, MA 01462

417. Manfred W. Langer

Volkswagen AG

Material Technology

3180 Wol fsburg 1

GERMANY AIR MAIL

418. James Lankford

Southwest Research Inst,itute

Department of Materiais

Sciences

6220 Culebra Road

San Antonio, TX 78228-0510

419. Stanley B. Lasday

Business News Publishing Co.

Manor Oak One

1910 Cochran Road, Suite 630

Pittsburgh, PA 15220

420. Mark S. Laser

Solar Turbines, Inc.

2211 Erie Street

San Diego, CA 92110

421. S. K. Lau

Carborundum Company

Technology Division

P.0. Box 832, B-100

Niagara Falls, NY 14302

422. Edward A. Lauder

Advanced Composite Materials Corporation

1525 South Buncombe Road

Greer, SC 29651-9208
423. J. Lawrence Lauderdale Babcock \& Wilcox

Contract Research Division 1850 "K" Street, Suite 950 Washington, DC 20006

424. Harry A. Lawler Carborundum Company Technology Division P.0. Box 832 Niagara Falls, NY 14302

425. Jean F. LeCostaouec Textron Speciality Materials 2 Industrial Avenue Lowe11, MA 01851

426. Benson P. Lee Interscience, Inc. 9718 Lake Shore Boulevard Cleveland, $\mathrm{OH} 44108$

427. Burtrand I. Lee Clemson University Department of Ceramic Engineering 01 in $\mathrm{Hall}$

Clemson, SC 29634-0907

428. June-Gunn Lee

KIST

Structural Ceramic Lab

P.0. Box 131, Cheong-Ryang

Seoul 130-650

KOREA AIR MAIL

429. Ran-Rong Lee

Ceramics Process Systems Corporation

155 Fortune Boulevard

Milford, MA 01757

430. Stan Levine

NASA Lewis Research Center

21000 Brookpark Road

MS: 49-3

Cleveland, $\mathrm{OH} 44135$

431. Alan V. Levy

Lawrence Berkeley Laboratory

One Cyclotron Road, MS:62-203

Berkeley, CA 94720 
432. Ai-Kang $\mathrm{Li}$

Materials Research Laboratories, ITRI 195-5 Chung-Hsing Road, Sec. 4 Chutung Hsinchu 31015 R.O.C. TAIWAN AIR MAIL

433. Winston $W$. Liang Hong Kong Industrial Technology Centre Co. Ltd.

78 Tat Chee Avenue

4/F, HKPC Building Howloon

HONG KONG AIR MAIL

434. Robert Licht

Norton Company

Advanced Ceramics

Goddard Road

Northboro, MA 01532-1545

435. E. Lilley

Norton Company

Advanced Ceramics

Goddard Road

Northboro, MA 01532-1545

436. Laura J. Lindberg

Allied-Signal Aerospace Company

Garrett Fluid Systems Division 1300 West Warner

MS: 93-901-1207-4TT

P.O. Box 22200

Tempe, AZ 85284-2200

437. Leonard C. Lindgren General Motors Corporation All ison Gas Turbine Division P.0. Box 420, Speed Code:T-20A Indianapol is, IN 46206-0420

438. Hans A. Lindner

Cremer forschungsinstitut GmbH\&CO.KG Oeslauer Strasse 35 D-8633 Rodental 8866 GERMANY AIR MAIL
439. Ronaid E. Loehman

Sandia National Laboratories

Chemistry \& Ceramics Department 1840

P. 0. Box 5800

Albuquerque, NM 87185

440. Jeffrey C. Logas

Winona State University

Composite Materials Engineering

115 Pasteur Hall

Winona, MN 55987

441. Bill Long

Babcock \& Wilcox

P.0. Box 11165

Lynchburg, VA 24506

442. William D. Long Wacker Chemicals (USA), Inc. ESK Engineered Ceramics

50 Locust Avenue

New Canaan, CT 06840

443. L. A. Lott

EG\&G Idaho, Inc.

Idaho National Engineering Laboratory

P.0. Box 1625

Idaho Falls, ID 83415-2209

444. Raouf 0. Loutfy

MER Corporation

7960 South Kolb Road

Tucson, AZ 85706

445. Gordon R. Love

Aluminum Company of America

Alcoa Technical Center

Alcoa Center, PA 15069

446. Lydia Luckevich

Ortech International

2395 Speakman Drive

Mississauga Ontario L5K 1 B3

CANADA AIR MAIL 
447. James W. MacBeth

Carborundum Company

Structural Ceramics Division

P.0. Box 1054

Niagara Falls, NY 14302

448. H. Maclaren

General Electric Company

Thomson Laboratory, Materials Engineering 36807

1000 Western Avenue

Lynn, MA 01910

449. George Maczura

Aluminum Company of America

Industrial Chemicals Division

670 One Allegheny Square

Pittsburgh, PA 15212

450. David Maginnis

Tinker AFB

OC-ALC/LIIRE

Tinker AFB OK 73145-5989

451. Frank Maginnis

Aspen Research, Inc.

220 Industrial Boulevard

Moore, OK 73160

452. Tai-il Mah

Universal Energy Systems, Inc.

Ceramics and Composites

Research

4401 Dayton-Xenia Road

Dayton, OH 45432

453. Kenneth M. Maillar

Barbour Stockwell Company

83 Linskey Way

Cambridge, MA 02142

454. Lorenzo Majno

Instron Corporation

100 Royall Street

Canton, MA 02021

455. S. G. Malghan

National Institute of Standards and Technology

I-270 \& Clopper Road

Gaithersburg, MD 20899
456. Lars Malmrup

United Turbine AB

Box 13027

Malmo S-200 44

SWEDEN AIR MAIL

457. John Mangels

Ceradyne, Inc.

3169 Redhill Avenue

Costa Mesa, CA 92626

458. Russell V. Mann

Matec Appl ied Sciences, Inc.

75 South Street

Hopkinton, MA 01748

459. William R. Manning

Champion Aviation Products Division

Old Norris Road

P.0. Box 686

Liberty, SC 29657

460. Ken Marnoch

Amercom, Inc.

8928 Fullbright Avenue

Chatsworth, CA 91311

461. Robert A. Marra

Aluminum Company of America

Alcoa Technical Center

Advanced Ceramics Center - E

Alcoa Center, PA 15069

462. Chauncey L. Martin

3M Company

3M Center, Building 60-1N-01

St. Paul, MN 55144

463. Steven C. Martin Advanced Refractory

Technologies, Inc.

699 Hertel Avenue

Buffalo, NY 14207

464. Kelly J. Mather

Williams International

Corporation

2280 West Maple Road

P.0. Box 200

Walled Lake, MI 48088 
465. James P. Mathers

3M Company

3M Center

Building 201-3N-06

St. Paul, MN 55144

466. Marshal1 Mayer

Instron Corporation

3815 Presidential Parkway, Suite 100

Atlanta, GA 30340

467. Ron Mayville

Arthur D. Little, Inc.

15-163 Acorn Park

Cambridge, MA 02140

468. F. N. Mazadarany

General Electric Company

Research Laboratory

Building K-1, Room MB-159

P.0. Box 8

Schenectady, NY 12301

469. James W. McCauley

Alfred University

NYS College of Ceramics

Binns-Merrill Hall

Alfred, NY 14802

470. Carolyn McCormick

Allied-Signal Aerospace Company

Garrett Auxiliary Power Division

B1dg. 1303-206

P.0. Box 5227, MS: $9317-2$

Phoenix, AZ 85010

471. Louis R. McCreight

2763 San Ramon Drive

Rancho Palos Verdes, CA 90274

472. Col in F. McDonald

McDonald Thermal Engineering

1730 Castellana Road

La Jolla, CA 92037

473. B. J. McEntire

Norton Company, TRW Ceramics

Goddard Road

Northboro, MA 01532-1545
474. Chuck McFadden

Coors Ceramics Company

600 9th Street

Golden, CO 80401

475. Henry McFadden

Magnetic Bearings, Inc.

Engineering Library

609 Rock Road

Radford, VA 24141

476. Thomas D. McGee

Iowa State University

Materials Science and

Engineering Department

110 Engineering Annex

Ames, IA 50011

477. Carol McGill

Corning Inc.

Sullivan Park, FR-02-08

Corning, NY 14831

478. T. C. McLaren

Cameron Forged Products Company

P.0. Box 1212

Houston, TX 77251-1212

479. James McLaught in

Sundstrand Power Systems

4400 Ruffin Road

P.0. Box 85757

San Diego, CA 92186-5757

480. Arthur F. McLean

6225 North Camino Almonte

Tucson, AZ 85718

481. Matt McMonigle

U.S. Department of Energy

Improved Energy Productivity Division

Forrestal Building, CE-231

Hashington, DC 20585

482. Dennis McMurtry

EG\&G Idaho, Inc.

Idaho National Engineering Laboratory

P.0. Box 1625

Idaho Falls, ID 83415 
483. D. B. Meadowcroft

National Power Technology and Environmental Centre

Kelvin Avenue

Leatherhead Surrey KT22 7SE

ENGLAND AIR MAIL

484. Jo Meglen

11004 Birdfoot Court

Reston, VA 22091

485. Pankaj K. Mehrotra

Kennametal, Inc.

P.0. Box 639

Greensburg, PA 15601

486. Joseph J. Meindl

Reynolds International, Inc.

6603 West Broad Street

P.0. Box 27002

Richmond, VA 23261-7003

487. Michael D. Meiser

Allied-Signal Aerospace Company

Garrett Ceramic Components

Division

19800 South Van Ness Avenue

Torrance, CA 90509

488. George Messenger

National Research Council of Canada

Engine Laboratory

Building M-7

Ottawa Ontario KIA OR6

CANADA AIR MAIL

489. D. Messier

U.S. Army Materials Technology Laboratory

SLCMT-EMC

405 Arsenal Street

Watertown, MA 02172-0001

490. Gary L. Messing

Pennsylvania State University

Ceramic Science and Engineering Department

119 Steidle Building

University Park, PA 16802
491. Arthur G. Metcalfe

Arthur G. Metcalfe and

Associates, Inc.

2108 East 24th Street

National Oity, CA 91950

492. R. Metselaar

Eindhoven University

Centre for Technical Ceramics

P.0. Box 513

Eindhoven 5600 MB

THE NETHERLANDS

AIR MAIL

493. Nancy S. Meyers

U.S. Department of Energy

Transportation Technologies

CE-30, Forrestal Building 6B-094

Washington, DC 20585

494. David J. Michael

Harbison-Walker Refractories Company

P.O. Box 98037

Pittsburgh, PA 15227

495. Ken Michaels

Chrysler Motors Corporation

Ceramics Development Metallurgical Processes

P.0. Box 1118, CIMS:418-17-09

Detroit, MI 48288

496. Bernd Michel

Institute of Mechanics

Fracture and Micromechanics Department

P.0. Box 408

D-9010 Chemnitz

GERMANY AIR MAIL

497. David E. Miles

Commission of the European Communities

rue de la Loi, 200

B-1049 Brusseis

BELGIUM AIR MAIL

498. John \%. Milewski

Superkinetics, Inc.

P.0. Box 8029

Santa Fe, NM 87504 
499. Carl E. Miller

AC Rochester 1300 North Dort Highway, MS: $32-31$

Engineering Building B

Flint, MI 48556

500. Mike Miller

McGraw-Hill Aviation Week

Performance Materials

1156 15th Street, N.W.

Washington, DC 20005

501. Charles H. Miller, Jr.

Centorr Furnaces/Vacuum Industries

542 Amherst Street

Nashua, NH 03063

502. R. Mininni

Enichem America

2000 Cornwall Road

Monmouth Junction, NJ 08852

503. Michele V. Mitchell

Allied-Signal Aerospace Company

Garrett Ceramic Components Division

19800 South Van Ness Avenue

Torrance, CA 90501-1149

504. Howard Mizuhara

GTE - WESGO

477 Harbor Boulevard

Belmont, CA 94002

505. Helen Moeller

Babcock \& Wilcox

P.0. Box 11165

Lynchburg, VA 24506-1165

506. Francois R. Mollard

Metalworking Technology, Inc.

1450 Scalp Avenue

Johnstown, PA 15904

507. Phil Mooney

Panametrics

NDE Division

221 Crescent Street

Wal tham, MA 02254
508. Thomas More1

Ricardo North America

645 Blackhawk Drive

Westmont, IL 60559

509. Geoffrey P. Morris

3M Company

3M Traffic Control Materials Division

B1dg. 209-BW-10, 3M Center

St. Paul, MN 55144-1000

510. Jay A. Morrison

Rolls-Royce, Inc.

Engineering and Information Center, Overlook 1

2849 Paces Ferry Road, Suite 450

Atlanta, GA 30339-3769

511. Joel P. Moskowitz

Ceradyne, Inc.

3169 Redhill Avenue

Costa Mesa, CA 92626

512. Brij Moudgil

University of Florida

Material Science and

Engineering

Gainesville, FL 32611

513. Christoph J. Mueller

Sprechsaal Publishing Group

P.O. Box 2962, Mauer 2 D-8630 Coburg GERMANY AIR MAIL

514. Thomas W. Mullan Vapor Technologies Inc. 345 Route 17 South Upper Saddle River, NJ 07458

515. M. K. Murthy

MKM Consultants International

10 Avoca Avenue, Unit 1906

Toronto Ontario M4T 2B7

CANADA AIR MAIL

516. Solomon Musikant

Transcon Technologies, Inc.

Materials Science \& Engineering 1508 Waynesboro Road

Paoli, PA 19301 
517. David L. Mustoe

Custom Technical Ceramics

8041 West I-70 Service Road, Unit 6

Arvada, CO 80002

518. Curtis V. Nakaishi

U.S. Department of Energy

Morgantown Energy Technology Center

Collins Ferry Road

P.0. Box 880

Morgantown, WV 26507-0880

519. Yoshio Nakamura

Faicera Research Institute

2-5-8 Hiyakun in-cho Shinjuku-Ko

Tokyo

JAPAN

AIR MAIL

520. K. S. Narasimhan

Hoeganaes Corporation

River Road

Riverton, NJ 08077

521. Samuel Natansohn

GTE Laboratories, Inc.

40 Sylvan Road

Waltham, MA 02254

522. Robert Naum

Applied Resources, Inc.

P.0. Box 241

Pittsford, NY 14534

523. Malcolm Naylor

Cummins Engine Company, Inc.

P.0. Box 3005, Mail Code 50183

Columbus, IN 47202-3005

524. Jeffrey Nei1

GTE Laboratories, Inc.

40 Sylvan Road

Wal tham, MA 02254

525. Fred A. Nichols

Argonne National Laboratory

9700 South Cass Avenue

MCT - Building 212

Argonne, IL 60439
526. H. Nickel

Furschungszentrum Jüelich (KFA) P.0. Box 1913 Jüelich 1-5170 BRD NRW GERMANY AIR MAIL

527. Dale E. Niesz

Rutgers University

Center for Ceramic Research

P.0. Box 909

Piscataway, NJ 08855-0909

528. David M. Nissley

United Technologies Corporation

Pratt \& Whitney Aircraft

400 Main Street, MS:163-10

East Hartford, CT 06108

529. Richard D. Nixdorf

ReMaxCo Technologies, Inc.

11317 Snyder Road

Knoxville, TN 37932

530. Bernard North

Kennametal, Inc.

P.0. Box 639

Greensburg, PA 15601

531. Bruce E. Novich

Ceramics Process Systems

Corporation

155 Fortune Boulevard

Milford, MA 01757

532. Daniel Oblas

GTE Laboratories, Inc.

40 Sylvan Road

Wal tham, MA 02254

533. Don Ohanehi

Magnetic Bearings, Inc.

1908 Sussex Road

Blacksburg, VA 24060

534. Robert Orenstein

General Electric Company

55-112, River Road

Schenectady, NY 12345 
535. Norb Osborn

Aerodyne Dallas

151 Regal Row,

Suite 120

Dallas, TX 75247

536. A. M. Paddick

BP International Limited

BP Research Centre, Main Library

Chertsey Road

Sunbury-on-Thames

Middlesex TW16 7LN

UNITED KINGDOM AIR MAIL

537. Russel1 J. Page

Kanthal-Artcor

3001 Redhill Avenue, II-109

Costa Mesa, CA 92705

538. Richard Palicka

Cercom, Inc.

1960 Watson Way

Vista, CA 92083

539. Muktesh Paliwal

GTE Products Corporation

Hawes Street

Towanda, PA 18848

540. Joseph E. Palko General Electric Company

55-113, River Road

Schenectady, NY 12345

541. Hayne Palmour, III North Carolina State University

Materials Science and

Engineering Dept.

Raleigh, NC 27605-7905

542. Joseph N. Panzarino

Norton Company

Advanced Ceramics

Goddard Road

Northboro, MA 01532-1545

543. Pellegrino Papa

Corning Inc.

MP-WX-02-1

Corning, NY 14831
544. E. Beth Pardue

Technology for Energy

Corporation

One Energy Center

P.0. Box 22996

Knoxville, TN 37933-0996

545. Soon C. Park

3M Company

3M Center

Building 142-4N-02

P.0. Box 2963

St. Pau1, MN 55144

546. Hartmut Paschke

Schott Glaswerke

Christoph-Dorner-Strasse 29

D-8300 Landshut

GERMANY AIR MAIL

547. Marina R. Pascucci

GTE Laboratories, Inc.

40 Syl van Road

Waltham, MA 02254

548. James W. Patten

Cummins Engine

Company, Inc.

Materials Engineering

P.0. Box 3005, Mail

Code 50183

Columbus, IN 47202-3005

549. Robert A. Penty

Eastman Kodak Company

KAD/D73 - 35612

901 Elmgrove Road

Rochester, NY 14653

550. Robert W. Pepper

Textron Specialty Materials

2 Industrial Avenue

Lowe11, MA 01851

551. Peter Perdue

Detroit Diesel Corporation

Research Advanced Development Group

13400 West Outer Drive, Speed Code A-07

Detroit, MI 48239-4001 
552. Bruce Peters

Dow Chemical Company

Building 52

Midland, MI 48667

553. John J. Petrovic

Los Alamos National Laboratory

Group MST-4, MS:6771

Los Alamos, NM 87545

554. Frederick S. Pettit University of Pittsburgh

Pittsburgh, PA 15261

555. Ben A. Phillips

Phillips Engineering Company

721 Pleasant Street

St. Joseph, MI 49085

556. Richard C. Phoenix

Ohmtek, Inc.

2160 Liberty Drive

Niagara Falls, NY 14302

557. Bruce J. Pletka

Michigan Technological University

Metallurgical and Materials

Engineering Department

Houghton, MI 49931

558. John P. Pollinger

Garrett Ceramic Components

19800 Van Ness Avenue

Torrance, CA 90501

559. P. Popper

High Technology Ceramics International Journal

22 Pembroke Drive

West l ands Newcastle-under-Lyme

Staffs ST5 $2 \mathrm{JN}$

ENGLAND AIR MAIL

560. F. Porz

Universitat Karlsruhe

Institut fur Keramik Im

Maschinendau

Postfach 6980

D-7500 Karl sruhe

GERMANY AIR MAIL
561. Harry L. Potma

Royal Netherlands Embassy

Science and Technology 4200 Linnean Avenue, N.W.

Hashingtor, DC 20008

562. Bob R. Powell

General Motors Research

Laboratories

Metallurgy Department

30500 Mound Road

Box 9055

Warren, MI 48090-9055

563. Stephen C. Pred

ICD Group, Inc.

1100 Valley Brook Avenue

Lyndhurst, NJ 07071

564. Karl M. Prewo

United Technologies Research Center

411 Silver Lane

MS:24

East Hartford, CT 06108

565. Peter E. Price

Industrial Materials Technology, Inc.

P. O. Box 9565

Andover, MA 01810

566. Joseph M. Proud

GTE Laboratories, Inc.

Materials Science Laboratory

40 Sylvan Road

Wal tham, MA 02254

567. Vimal K. Pujari

Norton Company

Advanced Ceramics

Goddard Road

Northboro, MA 01532-1545

568. George Quinn

National Institute of

Standards and Technology

Ceramics Division, Bldg. 223

Gaithersburg, MD 20899 
569. Ramas V. Ramain

Ceracon, Inc.

1101 North Market Boulevard, Suite 9

Sacramento, CA 95834

570. Charles F. Rapp

Owens Corning Fiberglass

2790 Columbus Road

Granville, $\mathrm{OH}$ 43023-1200

571. Dennis W. Readey

Colorado School of Mines

Department of Metallurgy and Materials Engineering Golden, CO 80401

572. Wilfred J. Rebello

PAR Enterprises, Inc.

12601 Clifton Hunt Lane

Clifton, VA 22024

573. Harold Rechter

Chicago Fire Brick Company

R\&D

7531 South Ashland Avenue

Chicago, IL 60620

574. Robert R. Reeber

U.S. Army Research Office

P.0. Box 12211

Research Triangle Park, NC 27709

575. K. L. Reifsnider

Virginia Polytechnic Institute and State University

Department of Engineering Science and Mechanics

Blacksburg, VA 24061

576. Paul E. Rempes

McDonnell Douglass Missle Systems Company

P.0. Box 516, Mail Code: 1066086

St. Louis, MO 63166-0516

577. Gopal S. Revankar John Deere Company Metals Research 3300 River Drive Moline, IL 61265
578. K. T. Rhee

Rutgers University

Mechanical Engineering

P.0. Box 909

Piscataway, NJ 08854

579. James Rhodes

Advanced Composite Materials Corporation

1525 South Buncombe Road

Greer, SC 29651

580. Roy W. Rice

W. R. Grace and Company

7379 Route 32

Columbia, MD 21044

581. David W. Richerson

2093 East Delmont Drive

Salt Lake City, UT 84117

582. Tomas Richter

J. H. France Refractories

1944 Clarence Road

Snow Shoe, PA 16874

583. Michel Rigaud

Ecole Polytechnique

Campus Universite De Montreal

P.0. Box 6079, Station A

Montreal, P.Q Quebec H3C 3A7

CANADA AIR MAIL

584. R. E. Riman

Rutgers University

Ceramics Engineering Department

P.0. Box 909

Piscataway, NJ 08855-0909

585. Barry Ringstrom

Superior Graphite Company

P.0. Box 2373

Smyrna, GA 30081

586. John E. Ritter

University of Massachusetts

Mechanical Engineering

Department

Amherst, MA 01003 
587. Frank L. Roberge

Allied-Signal Aerospace Company

Garrett Auxiliary Power Division

P.0. Box 5227

Phoenix, AZ 85010

588. W. Eric Roberts

Advanced Ceramic Technology, Inc. 990 " $F$ " Enterprise Street Orange, CA 92667

589. Martha Rohr

U.S. Department of Energy DOE Oak Ridge Field Office Building 4500N

P.0. Box 2008, MS: 6269

Oak Ridge, TN 37831-6269

590. Y. G. Roman

TNO TPD Keramick

P.0. Box 595

Einhoven 5600 AN

HOLLAND AIR MAIL

591. Mark D. Roos

Carborundum Company

P.0. Box 156

Niagara Falls, NY 14302

592. Michael Rossetti

Arthur D. Little, Inc.

15 Acorn Park

Cambridge, MA 01240

593. Barry R. Rossing Lanxide Corporation

1300 Marrows Road

Newark, DE 19714-6077

594. Steven L. Rotz

Lubrizol Corporation

29400 Lakeland Boulevard

Wickliffe, OH 44092

595. Bruce Rubinger

Global Competitiveness, Inc.

One Devonshire Place,

Suite 1011

Boston, MA 02109
596. Robert Ruh

Wright Laboratory

WL/MLLM

Wright-Patterson AFB, OH 45433

597. Robert J. Russe11

17 Highgate Road

Framingham, MA 01701

598. L. William Sahley

Supermaterials Company

24400 Highl and Road

Richmond Heights, $\mathrm{OH} 44143$

599. Jon Salem

NASA Lewis Research Center

21000 Brookpark Center

CTeveland, OH 44135

600. W. A. Sanders

NASA Lewis Research Center 21000 Brookpark Road,

MS: 49-3

Cleveland, $\mathrm{OH} 44135$

601. J. Sankar

North Carol ina A\&T State University

Department of Mechanical Engineering

Greensboro, NC 27411

602. Yasushi Sato

NGK Spark Plugs (U.S.A.), Inc.

1200 Business Center Drive, Suite 300

Mt. Prospect, IL 60056

603. Maxine L. Savitz

Allied-Signal Aerospace Company

Garrett Ceramic Components Division

19800 South Van Ness Avenue

Torrance, CA 90501

604. Ashok Saxena

Georgia Institute of Technology

Materials Engineering

Atlanta, GA 30332-0245 
605. David W. Scanlon

Instron Corporation

100 Royal1 Street

Canton, MA 02021

606. Charles A. Schacht

Schacht Consulting Services

12 Holl and Road

Pittsburgh, PA 15235

607. James Schienle

Allied-Signal Aerospace Company

Garrett Auxiliary Power

Division

2739 East Washington Street

P.n. Box 5227, MS: 1302-2P

Phoenix, AZ 85010

608. John C. Schneider

San Juan Technologies

P.0. Box 49326

Colorado Springs, CO 80949-9326

609. Gary Schnittgrund

Rocketdyne, BA05

6633 Canoga Avenue

Canoga Park, CA 91303

610. Mark Schomp

Lonza, Inc.

Corporate Headquarters

17-17 Route 208

Fair Lann, NJ 07410

611. Joop Schoonman

Delft University of Technology

Laboratory for Inorganic Chemistry

P.0. Box 5045

2600 GA Delft

THE NETHERLANDS AIR MAIL

612. John Schuldies

Industrial Ceramic

Technology, Inc.

37 Enterprise Drive

Ann Arbor, MI 48103
613. Robert B. Schulz

U.S. Department of Energy

Office of Transportation

Materials

CE-34, Forrestal Building

Washington, DC 20585

614. Murray A. Schwartz

Materials Technology Consulting, Inc.

30 Orchard Way, North

Potomac, MD 20854

615. Peter Schwarzkopf

SRI International

333 Ravenswood Avenue

Menlo Park, CA 94025

616. Thomas C. Schweizer

Princeton Economic Research, Inc. 12300 Twinbrook Pkwy., Suite 650

Rockville, MD 20852

617. William T. Schwessinger

Multi-Arc Scientific Coatings

1064 Chicago Road

Troy, MI 48083-4297

618. W. D. Scott University of Washington Materials Science Department Mail Stop:FB10

Seattle, WA 98195

619. Nancy Scoville Thermo Electron Technologies

74 West Street

P.0. Box 9046

Waltham, MA 02254-9046

620. Brian Seegmiller

Coors Ceramics Company

600 9th Street

Golden, CO 80401 
621. T. B. Selover

AICRE/DIPPR

3575 Traver Road

Shaker Heights, OH 44122

622. J. H. Selverian

GTE Laboratories, Inc.

40 Sylvan Road

Wal tham, MA 02254

623. Charles E. Semler

Semler Materials Services

4160 Mumford Court

Columbus, $\mathrm{OH} 43220$

624. Thomas Service

Service Engineering Laboratory

324 Wells Street

Greenfield, MA 01301

625. Kish Seth

Ethyl Corporation

R\&D Laboratories

P.0. Box 341

Baton Rouge, LA 70821

626. Karleen Seybold

Allied-Signal Aerospace Company

Garrett Auxiliary Power Division

P.0. Box 5227

Phoenix, AZ 85010

627. William J. Shack Argonne National Laboratory 9700 South Cass Avenue

Building 212

Argonne, IL 60439

628. Peter T. B. Shaffer

Technical Ceramics Laboratories, Inc. 4045 Nine/McFarl and Drive Alpharetta, GA 30201

629. Richard K. Shaltens NASA Lewis Research Center 21000 Brookpark Road, MS:301-2

Clevel and, $\mathrm{OH} 44135$
630. Robert S. Shane

238 Hemlock Road

Wynnewood, PA 19096

631. Daniel Shanefield

Rutgers University

Ceramics Engineering Department

P.0. Box 909

Piscataway, NJ 08855-0909

632. Ravi Shankar

Chromalloy

Research and Technology Division

Blaisdell Road

Orangeburg, NY 10962

633. Terence Sheehan

Alpex Wheel Company

727 Berkley Street

New Milford, NJ 07646

634. Dinesh K. Shetty

University of Utah

304 EMRO, Dept. of Materials

Science and Engineering

Salt Lake City, UT $\mathbf{8 4 1 1 2}$

635. Masahide Shimizu

Ceramic Society of Japan

2-2-503 Takiyama 6-chome

Higashikurume-Shi Tokyo 203

JAPAN AIR MAIL

636. John Shipinski

Toyota Technical Center

U.S.A., Inc.

Technical Research Department

2000 Town Center, Suite 500

Southfield, MI 48075

637. Thomas Shreves

American Ceramic Society, Inc.

Library

757 Brooksedge Plaza Drive

Westerville, $\mathrm{OH}$ 43081-2821

638. Jack D. Sibold

Coors Ceramics Company

Contracts for Corporate

Technology

4545 McIntyre Street

Golden, CO 80403 
639. George H. SiegeI

Point North Associates, Inc.

P.0. Box 907

Madison, NJ 07940

640. Richard Silberglitt

Technology Assessment and Transfer, Inc.

133 Defense Highway, \#212

Annapolis, MD 21401

641. Mary Silverberg

Norton Company

Advanced Ceramics Library

Goddard Road

Northboro, MA 01532-1545

642. Gurpreet Singh

Department of the Navy

Internal Combustion \& Gas

Turbine Engine Division

Code 56×31

Washington, DC 20362-5101

643. Maurice J. Sinnott

University of Michigan

Chemical and Metallurgical Engineering

5106 IST Building

Ann Arbor, MI 48109-2099

644. John Skildum

3M Company

3M Center

Building 224-25-25

St. PauT, MN 55144

645. David P. Smith

Hoskins, Rees \& Smith

1910 Cochran Road

Manor Oak II, Suite 658

Pittsburgh, PA 15220

646. Richard H. Smoak

Smoak \& Associates

3554 Hollyslope Road

Altadena, CA 91001-3923
647. Jay R. Smyth

Allied-Signal Aerospace Company

Garrett Auxiliary Power

Division

2739 East Washington Street

P.0. Box 5227

MS: $93-173 / 1303-207$

Phoenix, AZ 85010

648. Edward A. Snajdr

Premier Refractories and Chemicals, Inc.

P.0. Box 392

Findlay, $\mathrm{OH} 44815$

649. Rafal A. Sobotowski

British Petroleum Company

Technical Center, Broadway

3092 Broadway Avenue

Clevel and, $\mathrm{OH} 44115$

650. A. G. Solomah

SAC International Ltd.

1445 Bonhill Road, \#13

Mississauga Ontario L5T IV3

CANADA AIR MAIL

651. S. Somiya

Nishi Tokyo University

3-7-19 Seijo, Setagaya

Tokyo 157

JAPAN AIR MAIL

652. Boyd W. Sorenson

DuPont Lanxide Composites

1300 Marrows Road

P.0. Box 6077

Neward, DE 19707

653. Charles A. Sorrell

U.S. Department of Energy

Advanced Industrial

Concepts Division

CE-232, Forrestal

Building

Washington, DC 20585 
654. C. Spencer

EA Technology

Capenhurst Chester CHI 6ES

UNITED KINGDOM AIR MAIL

655. Allen Spizzo

Hercules, Inc.

Hercules Plaza

Wilmington, DE 19894

656. Richard M. Spriggs

Alfred University

Center for Advanced Ceramic Technology

Alfred, NY 14802

657. Charles Spuckler

NASA Lewis Reseurch Center

21000 Brookpark Road

MS: $5-11$

Cleveland, $\mathrm{OH}$ 44135-3191

658. M. Srinivasan

Material Solutions

P.0. Box 663

Grand Island, NY 14702-0663

659. Gordon L. Starr

Cummins Engine Company, Inc.

Design \& Technology

P.0. Box 3005

Mail Code 50182

Columbus, IN 47202-3005

660. Jim Stevenson

Windrock, Incorporated

154 Fairbanks Plaza

Oak Ridge, TN 37830

661. Tom Stillwagon

Allied-Signal Aerospace

Company

Garrett Ceramic Components

Division

19800 South Van Ness Avenue

Torrance, CA 90501

662. Harold L. Stocker

General Motors Corporation

Allison Gas Turbine Division P.O. Box 420

indianapolis, IN 46206
663. Paul D. Stone

Dow Chemical USA

1776 "Eye" Street, N.W., Suite 575

Washington, DC 20006

664. Roger S. Storm

Carborundum Company

Technology Division

P.0. Box 337

Niagara Falls, NY 14302-0337

665. Peter A. Stranges

4 Chittenden Lane

Owings Mills, MD 21117

666. F. W. Stringer

Aero \& Industrial

Technology Ltd.

P.0. Box 46, Wood Top

Burnley Lancashire BB11 4BX

UNITED KINGDOM AIR MAIL

667. Thomas N. Strom

NASA Lewis Research Center

21000 Brookpark Road

MS : 86-6

Clevel and, $\mathrm{OH} 44135$

668. M. F. Stroosnijder

Institute for Advanced

Materials

Joint Research Centre

21020 Ispra (VA)

ITALY AIR MAIL

669. Karsten Styhr

30604 Ganado Drive

Rancho Palos Vierdes, CA 90274

670. T. S. Sudarshan

Materials Modification, Inc. 2929-Pl Eskridge Center

Fairfax, VA 22031

671. M. J. Sundaresan University of Miami

Mechanical Engineering Department

P.O. Box 248294

Coral Gables, FL 33124 
672. Patrick L. Sutton

U.S. Department of Energy

Advanced Propulsion Division

CE-322, Forrestal Building

Washington, DC 20585

673. Willard H. Sutton

United Technologies

Corporation

Research Center, MS: 24

Silver Lane

East Hartford, CT 06108

674. Ron Sviben

100 Indel Avenue

Rancocas, NJ 08073

675. J. J. Swab

U.S. Army Materials Technology Laboratory

Ceramics Research Division

SLCMT-EMC

405 Arsenal Street

Watertown, MA 02172

676. Robert E. Swanson

Metalworking Technology, Inc. 1450 Scalp Avenue Johnstown, PA 15904

677. Scott L. Swartz

Battelle Columbus

Laboratories

Metals and Ceramics

505 King Avenue

Columbus, $\mathrm{OH} 43201$

678. Steve Szaruga

Rir Force Wright Aeronautical Laboratory

Materials Directorate

WL/MLBC

Wright-Patterson

AFB, OH 45433-6533

679. Yo Tajima

NGK Spark Plug Company, Ltd.

NTK Technical Ceramic Division

2808 Iwasaki

Komaki-shi Aichi-ken 485

JAPAN AIR MAIL
680. Fred Teeter

5 Tralee Terrace

East Amherst, NY 14051

681. Monika 0. Ten Eyck

Carborundum Company

Technology Division

P.0. Box 832

Niagara Falls, NY 14302

682. David F. Thompson

Corning Glass Works

SP-DV-02-1

Corning, NY 14831

683. Merle L. Thorpe

Hobart Tafa Technologies, Inc.

146 Pembroke Road

Concord, NH 03301

684. Eberhard Tiefenbacher

Daimler-Benz AG Abt. F1S

Mercedes-Strabe 136

Stuttgart 60

GERMANY AIR MAIL

685. T. Y. Tien

University of Michigan

Materials Science and

Engineering Department

Dow Building

Ann Arbor, MI 48103

686. Julian M. Tishkoff

Air Force Office of Scientific Research

AFOSR/NA

Bolling AFB, DC 20332-6448

687. D. M. Tracey

Norton Company

Advanced Ceramics

Goddard Road

Northboro, MA 01532-1545

688. Dick Trippett

General Motors Corporation

Allison Gas Turbine Division

P.0. Box 420, MS:H-16

Indianapolis, IN 46206-0420 
689. L. J. Trostel, Jr.

Box 199

Princeton, MA 01541

690. W. T. Tucker

General Electric Company

Corporate R\&D

Building K1-4C35

P.0. Box 8

Schenectady, NY 12301

691. Masanori Ueki

Nippon Steel Corporation

Central R\&D Bureau

1618 Ida

Nakahara-Ku Kawasaki 211

JAPAN AIR MAIL

692. Filippo M. Ugolini

ATA Studio

Via Degli Scipioni, 268A

ROMA 00192

ITALY AIR MAIL

693. Donald L. Vaccari

Allison Gas Turbines

P.0. Box 420

Speed Code 549

Indianapol is, IN 46206-0420

694. Carl F. Van Conant

Boride Products, Inc.

2879 Aero Park Drive

Traverse City, MI 49684

695. Marcel H. Van De Voorde

Commission of the European Communities

Institute for Advanced

Materials

Joint Research Centre

P.0. Box 2

1755 ZG Petten

THE NETHERLANDS AIR MAIL

696. 0. Van Der Biest

Katholieke Universiteit Leuven

Departement Metaalkunde en

Toegepaste

de Croylaan 2

B-3030 Leuven

BELGIUM AIR MAIL
697. Michael Vannier

Washington University, St. Louis

Mallinckrodt Institute of Radiology

510 South Kings Highway

St. Louis, MO 63110

698. Stan Venkatesan

Southern Coke \& Coal

Corporation

P.O. Box 52383

Knoxville, TN 37950

699. V. Venkateswaran

Carborundum Company

Niagara Falls R\&D Center

P.0. Box 832

Niagara Falls, NY 14302

700. Dennis Viechnicki

U.S. Army Materials Technology Laboratiory

405 Arsenal Street

Watertown, MA 02172-0001

701. Ted Vojnovich

U.S. Department of Energy

Office of Energy Research, ER-42

Washington, DC 20585

702. John D. Volt

E. I. Dupont de Nemours \& Company, Inc.

P.0. Box 80262

Wilmington, DE 19880

703. John B. Wachtman

Rutgers University

Ceramics Department

P.0. Box 909

Piscataway, NJ 08855

704. Shigetaka Wada

Toyota Central Research Labs, Inc.

Nagakute Aichi 480-11

JAPAN

AIR MAIL 
705. Janet Wade

Allied-Signal Aerospace Company

Garrett Auxiliary Power Division, Department 93-772

P.0. Box 5227, MS:1303-2

Phoenix, AZ 85010

706. Richard L. Wagner

Ceramic Technologies, Inc.

537 Turtle Creek South Drive, Suite 24D

Indianapol is, IN 46227

707. J. Bruce Wagner, Jr.

Arizona State University

Center for Solid State Science

Tempe, AZ 85287-1704

708. Daniel J. Wahien

Kohler, Co.

$444 \mathrm{Highl}$ and Drive

Kohler, WI 53044

709. Ingrid Wahlgren

Royal Institute of Technology

Studsvik Library

S-611 82 Nykoping

SWEDEN AIR MAIL

710. Ron H. Walecki

Allied-Signal Aerospace Company

Garrett Ceramic Components Division

19800 South Van Ness Avenue

Torrance, CA 90501

711. Michael S. Walsh

Vapor Technologies Inc.

2100 Central Avenue

Boulder, CO 80301

712. Chien-Min Wang

Industrial Technology Research Institute

Materials Research Laboratories 195 Chung-Hsing Road, Sec. 4 Chutung Hsinchu 31015 R.O.C. TAIWAN AIR MAIL
713. Robert M. Washburn

ASMT

11203 Colima Road

Whittier, CA 90604

714. Gerald Q. Weaver

Carborundum Specialty Products

42 Linus Allain Avenue

Gardner, MA 01440-2478

715. Karen E. Weber

Detroit Diesel Corporation

Technology and Planning

13400 West Outer Drive

Detroit, MI 48239-4001

716. R. W. Weeks

Argonne National Laboratory

MCT-212

9700 South Cass Avenue

Argonne, IL 60439

717. Ludwig Heiler

ASEA Brown Boveri AG

Corporate Research

Eppelheimer Str. 82

D-6900 Heidelberg

GERMANY AIR MAIL

718. James Hesse1

Dow Corning Corporation

1800 "M" Street, N.W.,

Suite 325 South

Washington, DC 20036

719. Robert D. West

Therm Advanced Ceramics

P.0. Box 220

Ithaca, NY 14851

720. Thomas J. Whalen

Ford Motor Company

26362 Harriet

Dearborn Heights, MI 48127

721. Ian A. White Hoeganaes Corporation

River Road

Riverton, NJ 08077 
722. Alan Whitehead

General Electric Company

1 River Road, 55-111

Schenectady, NY 12345

723. Sheldon M. Wiederhorn National Institute of Standards and Technology Building 223, Room A329 Gaithersburg, MD 20899

724. John F. Wight

Alfred University McMahon Building Alfred, NY 14802

725. D. S. Wilkinson McMaster University Materials Science and Engineering Department 1280 Main Street, West Hamilton Ontario L8S 4L7 CANADA AIR MAIL

726. James C. Williams General Electric Company Engineering Materials Technology Labs One Neumann Way Mail Drop: H85 Cincinnati, OH 45215-6301

727. Janette R. Williams Kollmorgen Corporation PCK Technology Division 150 Motor Parkway, \# 262 Hauppauge, NY 11788-5108

728. Steve J. Williams

RCG Hagler Bailly, Inc. 1530 Wilson Boulevard, Suite 900

Arlington, VA 22209-2406

729. Craig A. Will kene Norton Company Advanced Ceramics Goddard Road Northboro, MA 01532-1545
730. Roger R. Wills TRW, Inc.

Valve Division 1455 East 185th Street Clevel and, OH 44110

731. David Gordon Wilson Massachusetts Institute of Technology Mechanical Engineering Department

77 Massachusetts Avenue, Room 3-455

Cambridge, MA 02139

732. Matthew F. Winkler Seaworthy Systems, Inc.

P.0. Box 965

Essex, CT 06426

733. Gerhard Winter

Hermann C. Starck Berl in GmbH, Werk Goslar

P.0. Box 2540

D-3380 Gos lar 3380

GERMANY AIR MAIL

734. W. L. Winterbottom Ford Motor Company Material Systems Reliability Department 20000 Rotunda Drive SRL, Room E-3182 P.0. Box 2053 Dearborn, MI 48121

735. David G. Wirth Coors Ceramics Company 600 9th Street Golden, CO 80401

736. Thomas J. Wissing Eaton Corporation Engineering \& Research Center P.0. Box 766 Southfield, MI 48037

737. James C. Withers MER Corporation 7960 South Kolb Road Building $F$

Tucson, AZ 85706 
738. Dale E. Wittmer

Southern Illinois University

Mechanical Engineering Department

Carbondale, IL 62901

739. Warren W. Wolf Owens Corning Fiberglass 2790 Columbus Road, Route 16 Granville, OH 43023

740. George W. Wolter Howmet Turbine Components Corporation Technical Center 699 Benston Road Whitehall, MI 49461

741. Jamies C. Wood NASA Lewis Research Center 21000 Brookpark Road MS: 86-6 Clevel and, $\mathrm{OH} 44135$

742. Marrill Wood LECO Corporation Augusta Division P.0. Box 211688 Augusta, GA 30917-1688

743. Wayne L. Worrell University of Pennsylvania Department of Materials Science and Engineering 3231 Walnut Street Philadelphia, PA 19104

744. John F. Wosinski

Corning Inc.

ME-2 E-5 H8

Corning, NY 14830

745. Ian G. Wright

Battelle Columbus Laboratories $505 \mathrm{King}$ Avenue Columbus, $\mathrm{OH} 43201$

746. Ruth Wroe ERDC

Metals \& Materials Industries Division

Capenhurst Chester CH1 6ES ENGLAND AIR MAIL
747. Bernard J. Wrona Advanced Composite Materials Corporation 1525 South Buncombe Road Greer, SC 29651

748. Carl C. M. Wu

Naval Research Laboratory Ceramic Branch, Code 6373 Washington, DC 20375

749. John C. Wurst University of Dayton Research Institute 300 College Park Dayton, OH 45469-0101

750. Neil Wyant ARCH Development Corp. 9700 South Cass Avenue Building 202 Argonne, IL 60439

751. Roy Yamamoto Texaco Inc. P.0. Box 509 Beacon, NY 12508-0509

752. John Yamanis

Allied-Signal, Inc. Ceramics Program P.0. Box 1021 Morristown, NJ 07962-1021

753. Harry C. Yeh

Allied-Signal Aerospace Company

Garrett Ceramic Components Division 19800 South Van Ness Avenue Torrance, CA 90509

754. Hiroshi Yokoyama Hitachi Research Lab 4026 Kuji-Cho Hitachi-shi Ibaraki 319-12 JAPAN AIR MAIL

755. Thomas M. Yonushonis Cummins Engine Company, Inc. P.0. Box 3005 Mail Code 50183 Columbus, IN 47202-3005 
756. Thomas J. Yost

Corning, Inc.

Technical Products Division,

Main Plant 21-1-2

Corning, NY 14831

757. Jong Yung

Sundstrand Aviation Operations

Department 789-6

4747 Harrison Avenue

Rockford, IL 61125

758. A. L. Zadoks

Caterpillar Inc.

Technical Center, Building L

P.O. Box 1875

Peoria, IL 61656-1875

759. Avi Zangvil

University of Illinois

Materials Research Laboratory

104 South Goodwin Avenue

Urbana, IL 61801

760. Charles H. Zenuk

Transtech

6529 East Calle Cavalier

Tucson, AZ 85715

761. Anne Marie Zerega

U.S. Department of Energy

Office of Energy Research, ER-42

Washington, DC 20585

762. Ken Zillmer

Applied Test Systems, Inc.

2571 Mt. Gallant Road

Rock Hill, SC 29730

763. Carl Zweben

General Electric Company

P.0. Box 8555, VFSC/V4019

Philadelphia, PA 19101

764. Klaus M. Zwilsky

National Research Council

National Materials

Advisory Board

2101 Constitution Avenue

Washington, DC 20418
765. Department of Energy

DOE Field Office, Oak Ridge

Assistant Manager for Energy

Research and Development

P.0. Box 2001

Oak Ridge, TN 37831-8501

766-775. Department of Energy

Office of Scientific and

Technical Information

Office of Information

Services

P.0. Box 62

Oak Ridge, TN 37831

For distribution by microfiche as shown in DOE/OSTI-4500, Distribution Category UC-332 (Ceramics/Advanced Materials). 

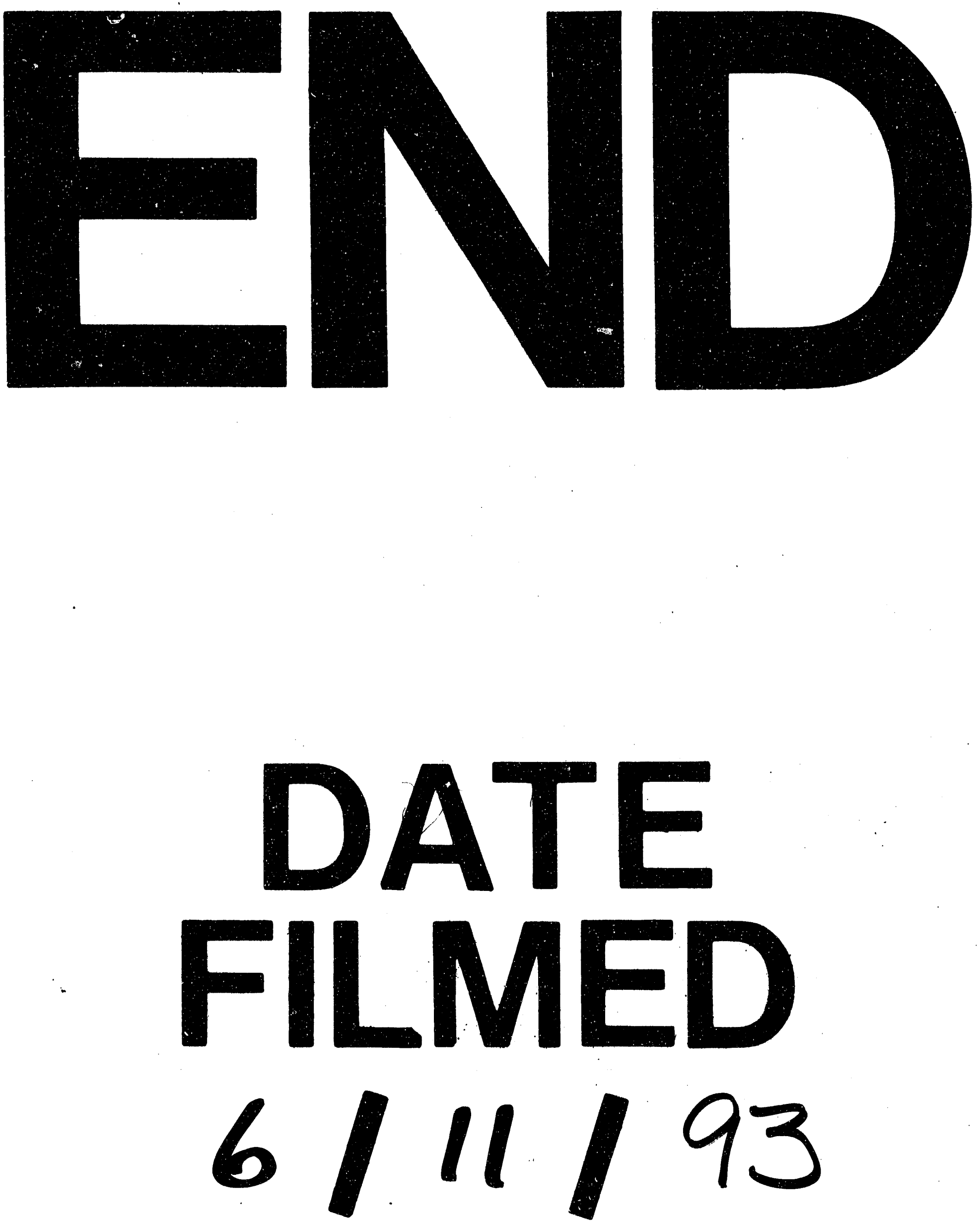
